\title{
Fluidized bed waste incinerators: design, operational and environmental issues
}

Van Caneghem J. ${ }^{a^{\star}}$, Brems A. ${ }^{b}$, Lievens P. ${ }^{a, c}$, Block C. ${ }^{a}$, Billen P. a, Vermeulen I. ${ }^{a}$, Dewil R. ${ }^{b}$, Baeyens J. ${ }^{d}$, Vandecasteele $\mathrm{C}^{\mathrm{a}}$

a Lab of Applied Physical Chemistry and Environmental Technology, Department of Chemical Engineering, University of Leuven, W. De Croylaan 46, B-3001 Heverlee, Belgium

b Chemical and Biochemical Process Technology and Control Section, Department of Chemical Engineering, University of Leuven, W. De Croylaan 46, B-3001 Heverlee, Belgium

c "Groep T" Engineering College, A. Vesaliusstraat 13, B-3000 Leuven, Belgium d College of Life Science and Technology, Beijing University of Chemical Technology, Beijing, China

* Corresponding author: Tel.: +32 16 322353; fax +32 16 322991. E-mail address: jo.vancaneghem@cit.kuleuven.be 


\section{Abstract}

The paper starts by reviewing the increasing production of waste and the growing importance of its thermal treatment, which aims at volume reduction of the waste, at the destruction, capture, and concentration of hazardous substances, and at the recovery of energy (WtE).

Incineration is a generally applied thermal treatment technique, whereas pyrolysis and gasification are still under development. Within the incineration techniques, bubbling, rotating and circulating fluidized beds have found specific and growing applications. As technical information on fluidized bed waste incinerators is spread throughout literature, the present review paper collates the relevant literature and critically examines the parameters that govern the design and operation of these incinerators.

Secondly, the design strategy of a fluidised bed incinerator is outlined, which involves considerations of hydrodynamic (velocities, mixing), thermal (heat balances) and kinetic (reaction rate and burn-out) nature. Application of the design equations and recommendations will facilitate the sizing of an appropriate fluidized bed incinerator.

Since during waste incineration pollutants are formed, the origin and fate of the pollutants and their abatement are reviewed.

Finally, special attention is given to the specific de-fluidization problems often encountered during fluidized bed combustor operation, mainly because of agglomeration and sintering. The mechanisms of agglomeration and sintering are discussed, and possible remedies are given. Additionally, important issues of equipment erosion and uniform feeding of the waste into the fluidized bed reactor are considered. 


\section{Keywords}

Fluidized bed combustor, waste incineration, waste disposal, waste-to-energy, design, de-fluidization, pollutant, operational data

Table of contents

Abstract

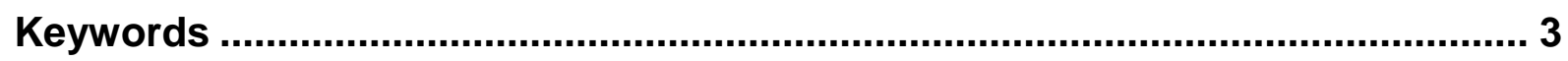

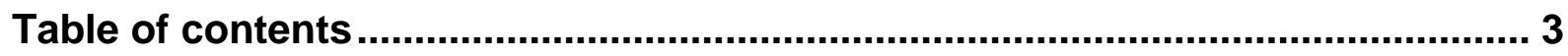

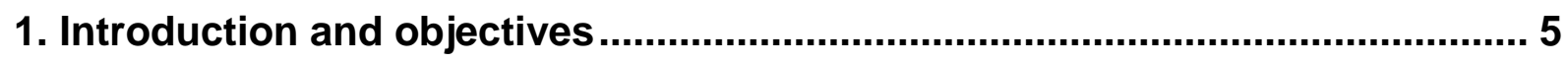

1.1. Waste production and disposal .............................................................. 5

1.2. Technologies for thermal treatment of waste; waste incineration in

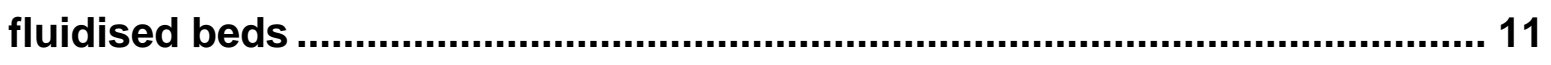

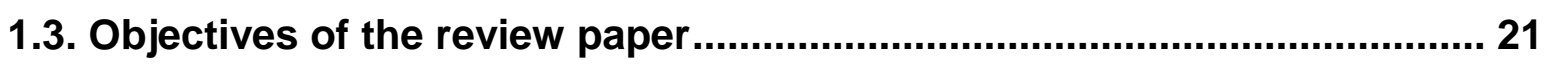

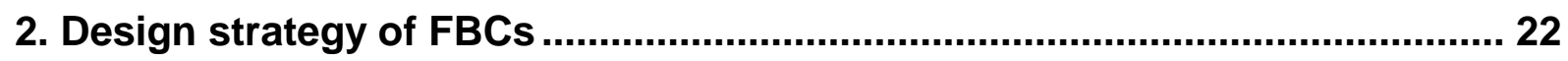

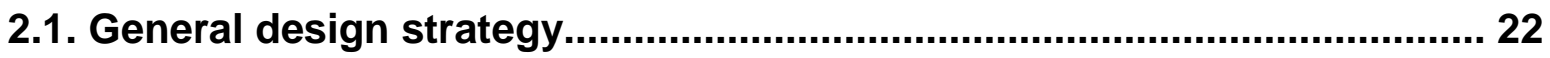

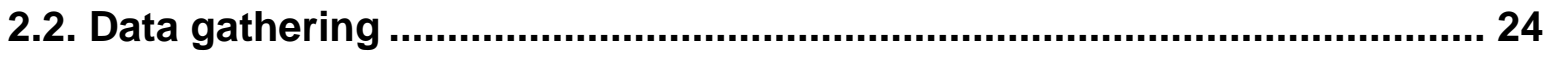

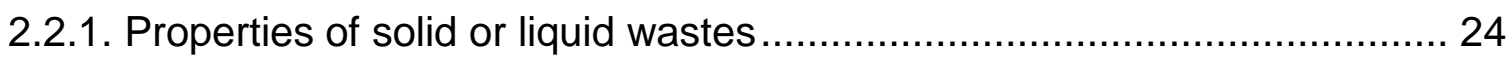

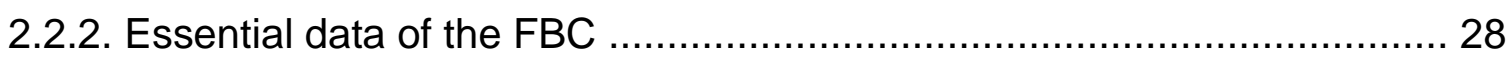

2.3. Heat balance, net energy yield and flow rates ........................................ 32

2.4. Operating gas velocity and cross sectional area of the combustor ........ 34

2.5. Combustion kinetics and required residence time .................................. 35

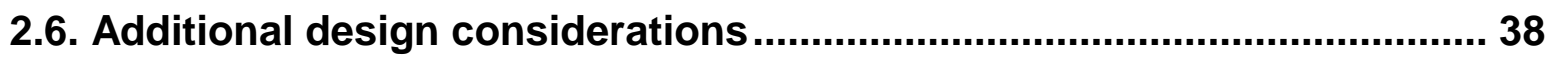




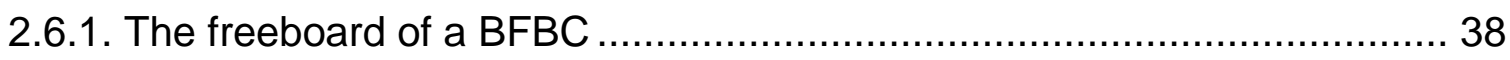

2.6.2. Additional considerations for a CFBC ................................................ 40

3. Stack emissions: Problems and remedies ................................................ 41

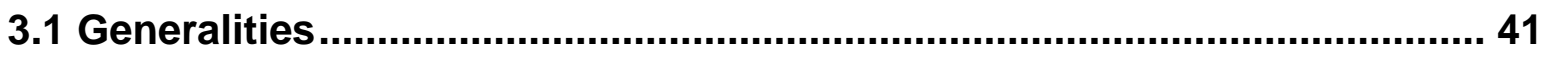

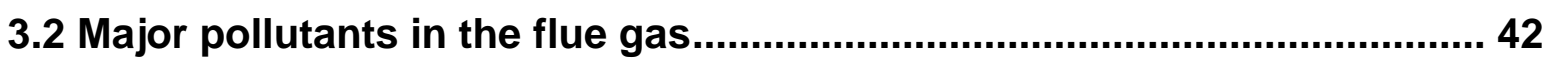

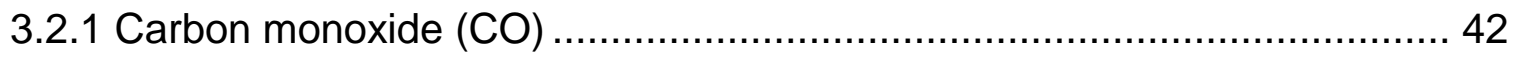

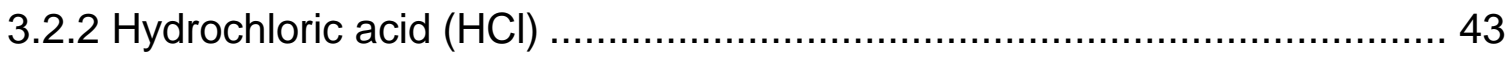

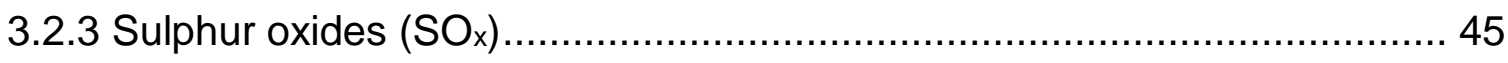

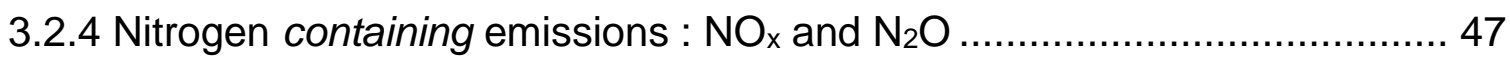

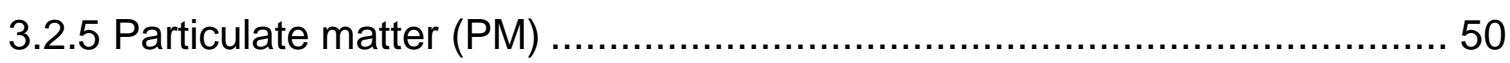

3.3. Pollutants present in both flue gas and ashes ....................................... 52

3.3.1. Polychlorinated dioxins and furans (PCDD/Fs) .................................. 52

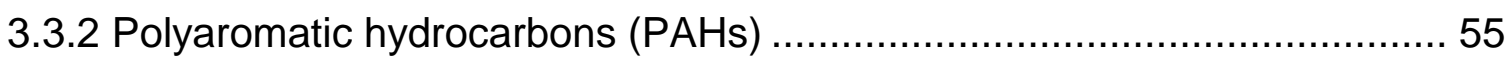

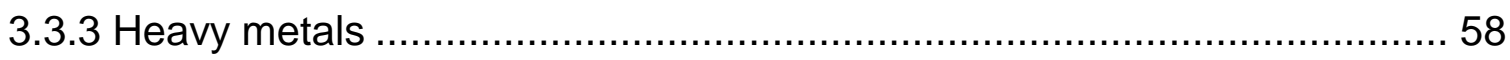

4. Operating problems during FB waste incineration......................................... 64

4.1. Agglomeration, sintering and de-fluidization ............................................ 64

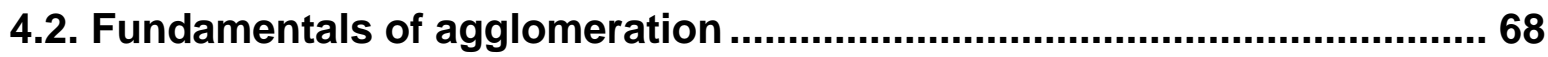

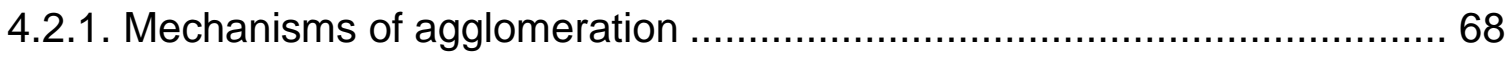

4.2.2. The chemistry of agglomeration ........................................................... 71

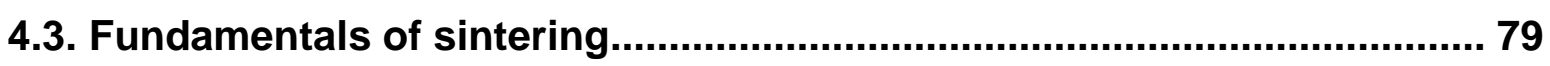

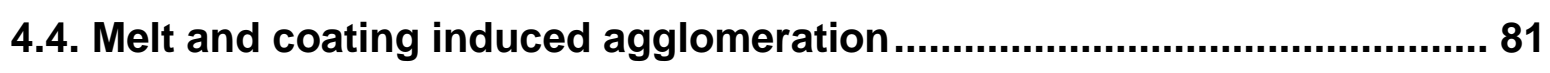

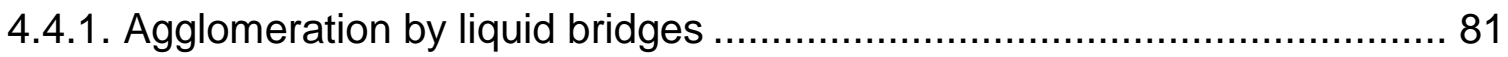

4.4.2. Melt and coating induced agglomeration............................................... 82

4.5. The fuel particle temperature as important parameter in de-fluidization

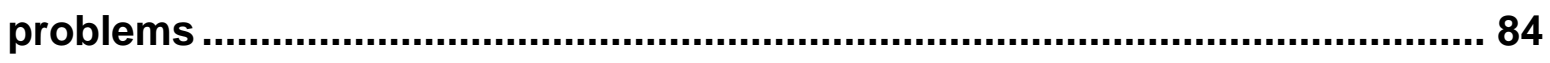




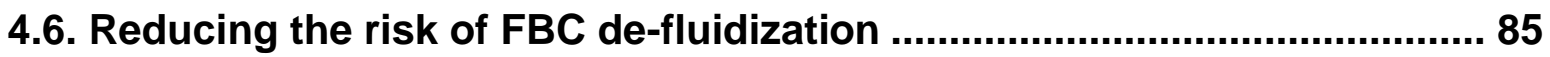

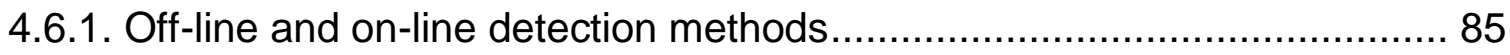

4.6.2. Effect of operating parameters on the de-fluidization time ...................... 86

4.6.3. Methods to reduce the risk of agglomeration and sintering .................... 87

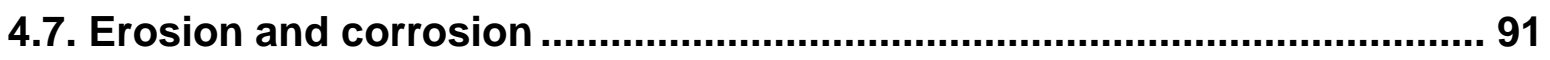

4.8. Practical considerations for FBC boilers …............................................. 92

4.9. Feeding

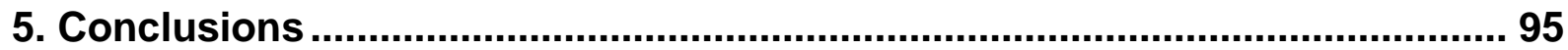

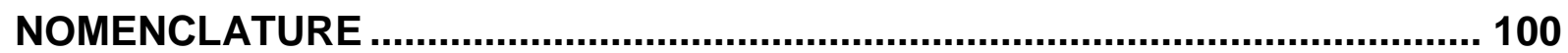

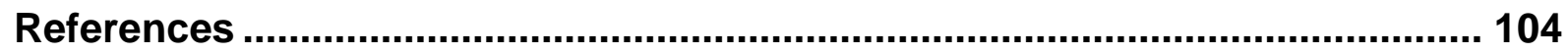

\section{Introduction and objectives}

\subsection{Waste production and disposal}

This section discusses waste production, the waste treatment hierarchy and waste treatment options including recycling, landfill, incineration and waste-to-energy (WtE) technologies. Special attention is given to the impact on climate change of these waste treatment techniques. For each issue, the situation in Europe, in the US and other high GDP-countries, in China, in India and, where possible, in some low income countries is reviewed.

In modern industrialized society, large quantities of waste are produced. In the EU27, about 2600 Mton ( $10^{6}$ metric ton) of waste were generated in 2008 , corresponding to $5300 \mathrm{~kg} / \mathrm{capita}$. Municipal solid waste (MSW) collected by or on behalf of municipalities and including waste produced by households and similar waste from e.g. offices and small business amounts to $520 \mathrm{~kg} /$ capita [1]. In Europe, MSW thus 
corresponds only to about $10 \%$ of the total waste generated. Table 1 shows that the amounts of construction waste, of waste from the manufacturing industry and of mining waste significantly exceed those of MSW.

Table 1. MSW and industrial waste in the EU25(a) in 2002 [1].

\begin{tabular}{|l|l|l|l|l|l|l|l|l|}
\hline EU25 & $\begin{array}{l}\text { Agriculture } \\
\text { and forestry }\end{array}$ & $\begin{array}{l}\text { Mining } \\
\text { and } \\
\text { quarrying }\end{array}$ & $\begin{array}{l}\text { Manu- } \\
\text { facturing } \\
\text { industry }\end{array}$ & $\begin{array}{l}\text { Energy } \\
\text { production, } \\
\text { water } \\
\text { treatment }\end{array}$ & Construction & Others & MSW & $\begin{array}{l}\text { Hazardous } \\
\text { waste }\end{array}$ \\
\hline Mton & 29 & 300 & 425 & 127 & 510 & 17 & 241 & 58 \\
\hline $\mathrm{kg} /$ capita & 64 & 664 & 994 & 281 & 1126 & 28 & 531 & 129 \\
\hline
\end{tabular}

(a) EU25, prior to the EU-membership of Romania and Bulgaria

In the US, MSW generation was estimated at 351Mton in 2008, corresponding to $1200 \mathrm{~kg} / \mathrm{capita}$ [2], and generation of industrial waste at 7.6 Gton corresponding to 26 $000 \mathrm{~kg} /$ capita [3]. Annual MSW production worldwide ranges from 350 to $1200 \mathrm{~kg}$ MSW/capita in high-income countries, from 250 to $550 \mathrm{~kg} \mathrm{MSW/capita} \mathrm{in} \mathrm{medium-}$ income countries and from 150 to $250 \mathrm{~kg} /$ capita/year in low-income countries [4]. Under the industrial wastes, sludge holds an important position for the purpose of this review. In the EU-27, wastewater treatment plants (WWTPs) produced 0-30 kg sludge (dry solids, DS) per capita in 2009. In Flanders, Belgium, sludge production (2009) comprised about 92 kton (DS) of WWT sludge, 9.4 kton of drinking water sludge, 44 kton of sewer sludge, 30 kton of sludge from the food industry, 115 kton sludge from the of de-inking industry and 4.7 kton of sludge from the textile industry [5-7]. The US produces yearly 6.5 Mton WWT sludge corresponding to $29 \mathrm{~kg} / \mathrm{capita}$ (dry solids content not specified).

In most countries, controlled and uncontrolled landfill of waste is the main final disposal method. In contrast to MSW, which is suitable for incineration with energy recovery as a result of its $70 \%$ combustible organics content, industrial waste is mostly inorganic which makes recycling and landfill more suitable treatment options than incineration. Densely populated industrialised countries generally try to divert 
recyclable and combustible waste from landfill, initially to reduce land areas occupied by landfills, and more recently driven by the increasing awareness for resource conservation and climate change. Indeed, recycling and energy recovery from nonrecyclable combustible waste alleviates the use and dependence of fossil fuel and of other resources.

The European Landfill Directive 1999/31/EC, imposes EU-member states by 2016 to reduce the amount of biodegradable waste landfill by $65 \%$ in comparison with the 1995 situation. Ten countries of the EU27 already met the target in 2010, with Germany, The Netherlands, Sweden, Austria, Denmark and Belgium as most successful in reducing the dependence on landfill by combining material recycling, biological treatment (composting and anaerobic digestion) and WtE technology. This is clearly shown in Figure 1, where the percentage of MSW recycled and composted, incinerated and landfilled is compared for the EU27 countries, showing major differences between the member states. The Waste Framework Directive 2008/98/EC sets the hierarchy of the waste policy and management, with Prevention, Preparing for re-use, Recycling, Other recovery (e.g. energy recovery), and Disposal as options of decreasing priority. 


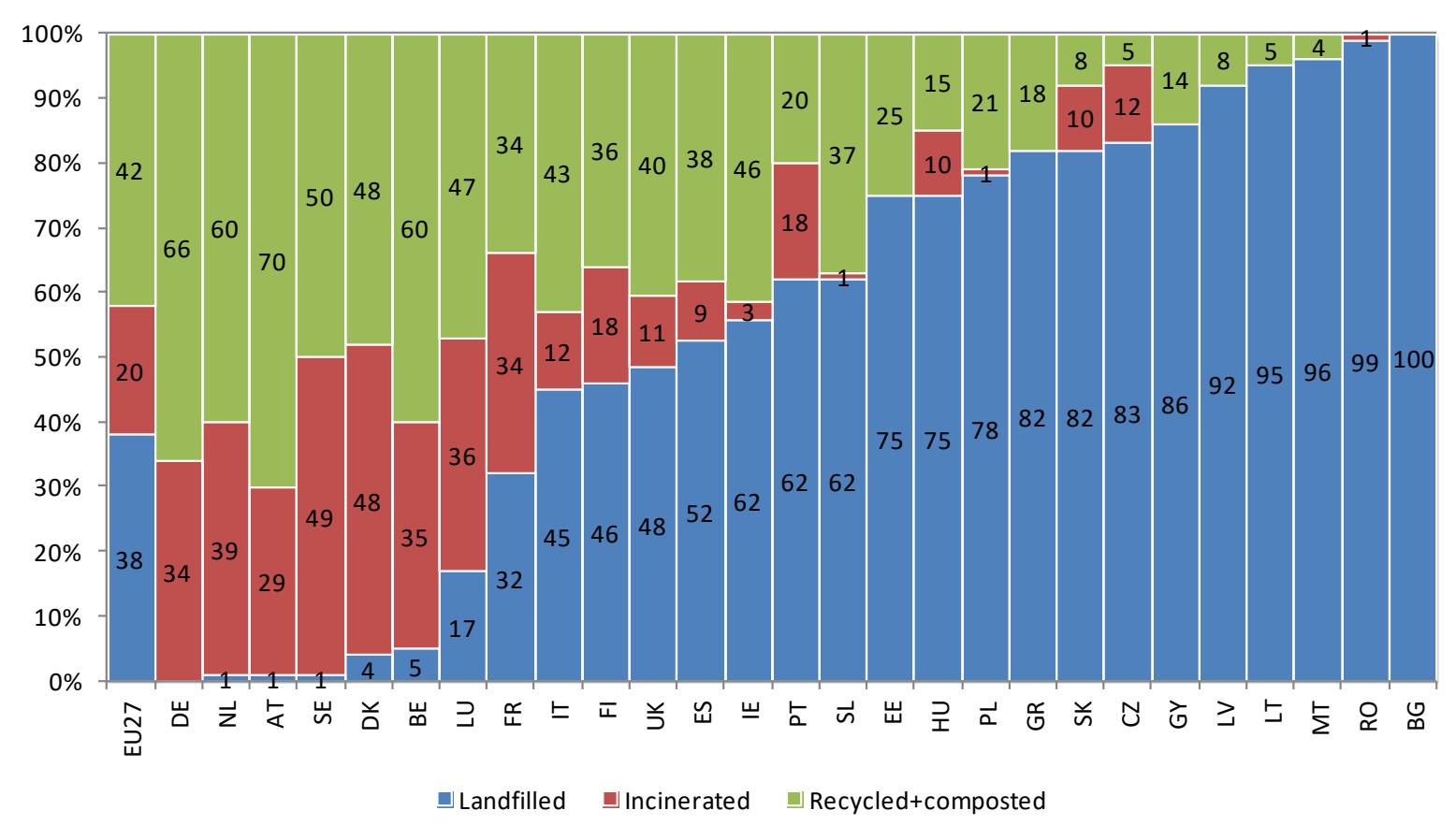

Figure 1. Treatment of MSW in EU27 [8]

As a consequence of the coordinated efforts of the EU27 countries, MSW-landfill dropped from $57 \%$ (1998) to $39 \%$ (2008), while incineration increased from $14 \%$ to $19 \%$ over the same period. From the total amount of waste (MSW + industrial waste) generated by the EU-27 members in $2008,48.9 \%$ was landfilled, only $5.4 \%$ (mainly MSW) incinerated and $45.7 \%$ recovered $[1,4,9]$. As a specific case, the situation relative to MSW and industrial waste treatment in Flanders (Northern part of Belgium with 6.3 million inhabitants) is given: in 2009 3.4 Mton of MSW was generated, with $72 \%$ selectively collected for reuse and recycling; of the residual $28 \%$, being collected in special plastic bags or containers, $25 \%$ is incinerated and $3 \%$ is landfilled. Segregated waste collection provides high levels of recycling. The situation in Flanders is slightly different from Belgium as a whole (Figure 1). In 200821.8 Mton of industrial waste was generated in Flanders, of which $63 \%$ was used for material recycling, $11 \%$ was incinerated, $8 \%$ was landfilled, and the balance was treated several times [10]. 
A number of high-GDP countries (Australia, Canada, the US and New-Zealand) did not yet legally discourage landfilling, which thus remains the cheapest and preferred disposal option. A similar and even more detailed waste treatment hierarchy than in the EU was however promoted in the US, particularly by the Waste-to-Energy Research and Technology Council (WTERT). To date in the US, $69 \%$ of the MSW is landfilled, $24 \%$ is recycled and composted and $7 \%$ is incinerated $[2,11]$. A WTERT survey of 2007 showed that the global capacity for waste incineration with energy recovery increased in the period 2001-2007 by about 4 Mton per year.

According to estimates of the Zhejiang University, 668 cities in China landfilled about 235 Mton of MSW in 2007, whilst the annual growth of MSW amounts to $6-8 \%$. The accumulated amount of MSW in non-regulated landfills was estimated at 6 Gton [1213].

Approximately 130 Mton of waste are currently incinerated across 35 countries of the Organisation of Economic Co-operation and Development (OECD) [14]. In Europe about $50 \mathrm{Mton} / \mathrm{year}$ of waste are currently (2007) thermally treated in some 420 waste-to-energy $(\mathrm{WtE})$ plants. Denmark and Luxembourg treat more than $50 \%$ of the MSW through incineration, mostly with energy recovery. France, Sweden, the Netherlands, Belgium and Switzerland also have high rates of incineration with energy recovery [14]. In $2010 \mathrm{WtE}$ plants in Europe supplied about $5010^{9} \mathrm{kWh}$ of renewable energy. In 2020, generation of $6710^{9} \mathrm{kWh}$ of renewable energy is expected, a figure that can grow to $9810^{9} \mathrm{kWh}$ if all MSW remaining after waste prevention, reuse and recycling (about 70 Gton in 2008) is used in WtE plants [15]. Estimates depend on whether electricity, heat or combined heat and power (CHP) are assumed to be produced. European waste incinerators are reported to have conversion efficiencies of $15-30 \%$ for electricity production and $60-85 \%$ for heat 
production (\% based on the lower heating value of the waste) [16]. In Northern, Central and Eastern Europe it is fairly common to find district heating networks powered by waste incinerators. As an example, three WtE plants supply heat to the network of Copenhague, one of the world's largest district heating networks in Europe $(50 \mathrm{~km})$. The waste incinerators from Indaver in Doel (Belgium) generate 780 $000 \mathrm{MWh} /$ year, corresponding to the electricity consumption of 220000 families, in addition to generating steam which is distributed to nearby industry. Also different UK WtE plants (e.g. Runcorn) provide heat and/or power to adjacent industries.

The highest rate of thermal waste treatment in the world is encountered in Japan (40 Mton/year), where transportation of "as collected" MSW from one municipality to another is not encouraged. As a result WtE facilities are often relatively small or MSW is processed to refuse derived fuel (RDF) and then transported to a central WtE that serves several communities.

China counted about 67 WtE plants in 2007 with a total capacity of 4 Mton. The rapid development of WtE in China has been enhanced by scarcity of land near cities, by the ability of recovering energy and by government incentives for WtE: the incineration of MSW with energy recovery increased from $1.7 \%$ in 2000 to $5 \%$ in 2005. Due to the high efficiency of scavenging recyclable materials, Chinese MSW has a calorific value of $5 \mathrm{MJ} / \mathrm{kg}$ only, half the EU or US value, and is usually mixed with $15 \%$ coal when incinerated [12].

In low-income countries, waste is characterized by a low calorific value (3-4 MJ/kg), a high percentage of putrescent waste (50-80\%) and a high moisture content, making it unsuitable for incineration without considerable pre-treatment. India had limited success with thermal treatment projects, turning MSW into refuse derived fuel (RDF) 
to produce energy or to supplement fuel for cement kilns, as the recycling sector in Indian cities recovers much of the dry, high calorific material from MSW, leaving a moist residue with high green waste content. The organic fraction is subjected to composting in ward level composting units, whereas the non-recyclable fraction is disposed off in landfills [4, 17].

Bogner et al. [14] estimated the 2009 worldwide impact of waste incineration on climate change at 40 Mton $\mathrm{CO}_{2}-\mathrm{eq}$, compared to 700 Mton $\mathrm{CO}_{2}$-eq for waste landfilling. The European Environment Agency states that recycling and incineration with energy recovery of MSW will result in a considerable reduction of the emission of CO2-equivalents by 2020 in the EU27. Depending on the scenario examined, this reduction will vary from 45 to $146-244$ Mton/year, the latter corresponding to a reduction by $24-41 \%$ of the $\mathrm{CO}_{2}$ emissions to be realized by $2020[15,18]$.

\subsection{Technologies for thermal treatment of waste; waste incineration in fluidised beds}

Thermal treatment aims at a volume reduction of the waste; at the destruction, capture, and concentration of hazardous substances; and evidently at the recovery of energy (WtE). Thermal treatment technologies, applied to industrial, agricultural, and municipal solid waste, include mainly high temperature incineration, gasification and pyrolysis.

Mass-burn incineration refers to combustion of MSW in a furnace with little or no prescreening or separation and is the most commonly applied technology. It can be performed in a grate-furnace incinerator, a fluidized bed incinerator, or a rotary kiln. 
Plasma incineration, gasification and pyrolysis may also be used, but should still be considered as emerging technologies [16,19-20].

In a fluidized bed combustor (FBC), a bed of sand, combustion ash, or other sandlike material is suspended in an upward flowing airstream. The high turbulence created enhances combustion and promotes efficient heat transfer and uniform mixing. Three types of fluidized bed reactors are used for waste incineration: the traditional bubbling fluidized bed (BFBC), the rotating fluidized bed (RFBC) and the (external) circulating fluidized bed (CFBC).

In bubbling fluidized bed combustors (BFBC), an initially stationary bed of solid particles, located in the bottom part of the combustor, is brought into a fluidized state by primary air, supplied through a distributor: the bed particles are kept in suspension at fluidization velocities between 0.5 and $3.0 \mathrm{~m} / \mathrm{s}$. For BFBC applications, the size distribution of the feed should be carefully considered, to avoid excessive carry-over of fines prior to complete burnout, or segregation of large particle that will not fluidize properly. BFBC are applied for e.g. coal, bio-solids, plastic solid waste and wastewater treatment sludge. The particles collected in the primary cyclone of a BFBC are usually partly returned to the bed to achieve a high degree of burnout. In contrast to BFBCs, rotating fluidized bed combustors (RFBC) rely on an uneven distribution of the primary air over the distributor, causing an internally imposed circulation through the sand bed with zones of strong aeration (upflow sand stream) and zones with less aeration (downflow sand stream), and creates an imposed mixing pattern [21], extending the use of bubbling fluidized beds to a wide range of waste types and sizes, from sludge to MSW and comparable industrial waste, after minimal pretreatment. The feed size of a RFBC can moreover be coarser $(<30 \mathrm{~mm})$ 
than in a traditional BFBC $(<10 \mathrm{~mm})$ since the RFB-imposed bed circulation guarantees a more readily mixed feed and bed material.

In (external) circulating fluidized beds (CFBCs), higher gas velocities of (3.0 to 9.0 $\mathrm{m} / \mathrm{s}$ ) are employed, and solids are continuously carried out of the combustor. The well defined surface of the bed, prominent in BFBCs and RFBCs, disappears, and different solids transport modes occur ranging from lean to dense transport [22]. The entrained particles are separated in an external cyclone and almost completely returned to the bottom of the fluidization vessel, hence the name of (external) circulating fluidized bed. Particles below the cut-size of the cyclone (ash) are carried forward to the boiler and de-dusting part of the plant.

In BFBC, RFBC and CFBC, secondary air is generally used. In a BFBC and RFBC, it is introduced at the top of the bed (splash zone) and further higher up (freeboard, also called tertiary air) through well distributed air inlets over the entire width of the freeboard. In a CFBC, secondary and tertiary air are introduced in the riser, at some distance above the re-entry point of the solids from the external recycle loop. The temperature normally varies between 800 and $900^{\circ} \mathrm{C}$. For a waste feed of high calorific value, the temperature is controlled by either an internal heat exchanger, or by the amount of cold air fed to the combustor. For very wet feeds of low calorific value, such as sludge, pre-heated air is commonly used as fluidizing gas.

Fluidized bed incineration offers a high potential for the treatment of several types of industrial waste, for sewage sludge, and more recently also for MSW. Fluidised bed incineration has several advantages compared to more traditional incinerators such as grate furnaces: 
- It is adaptable to a wide variety of waste types. New developments reduce also the required extent of pre-treatment to reduce size, as they accept coarser waste materials. Older types of fluidized bed incinerators necessitated extensive size reduction to obtain a small particle size of good homogeneity.

- The technique is suited to burn high moisture wastes with low calorific value, such as sludge. In this case, pre-heating of the fluidization air, and/or a predrying of the wet sludge feed is generally required in order to reach the required incineration temperature of about $800^{\circ} \mathrm{C}$. An interesting development consists in co-incinerating sludge with high calorific waste. Part of the energy in the high calorific waste is then in fact used to evaporate water from the sludge whilst the excess heat is used to generate steam and electricity (energy recovery). In Flanders, Belgium, 83 kton (corresponding to $90 \%$ of total production) of WWT sludge and 120 kton (corresponding to $80 \%$ of total production) of industrial sludge were incinerated in 2009, mainly in FBCs [7]. Due to the thermal inertia of the bed, changes in moisture content and calorific value of the waste can more easily be absorbed by the system than in traditional thermal waste treatment systems e.g. grate furnaces [23-24].

- The eroding action of the turbulently mixed bed material on the waste particles strips away carbonates and char layers formed around the waste particles: $\mathrm{O}_{2}$ reaches the combustible waste more readily, hence increasing the rate and the efficiency of the combustion.

- Turbulence in the freeboard along with the scouring effect and the thermal inertia of the bed material assures complete, controlled and uniform incineration (complete burnout) with a minimum amount of char in the residues and low stack emissions. Emissions are lower than in other technologies, with 
low combustion temperatures and low excess air reducing $\mathrm{NO}_{x}$ formation, whilst the high combustion efficiency significantly reduces $\mathrm{CO}$ levels.

Despite these advantages some design challenges for fluidized bed combustors need to be considered [25]:

- As already mentioned in the previous paragraph, fuel preparation is sometimes required. An example is the size reduction of coarse wastes as these can negatively influence the fluidization of the bed, resulting in operational problems. Another example is the removal of alkali metal components by a leaching process to prevent corrosion and agglomeration problems [26].

- If waste with highly different $\mathrm{HHV}$ is co-incinerated, proper mixing before introduction of the waste is essential.

- For waste types with a high ash content, a well designed system for ash removal must be present [27].

- A high chlorine content of the waste can enhance boiler corrosion and bed agglomeration (as discussed in Section 4), and causes increased emissions of pollutants, such as $\mathrm{HCl}$ and PCDD/Fs (as discussed in Section 3).

Wastes such as wood bark, petroleum coke and polyolefin plastics are applicable for fluidized bed incineration without considerable challenges. The incineration of wood biomass, coloured or printed plastics, and plywood presents however some challenges for the operation and the boiler design. Multiple design and operational challenges including size reduction and mixing of the different wastes have to be dealt with when demolition wood, fibre residue, PVC, RDF and MSW are incinerated [25]. 
The application of BFBCs to slurries, sewage sludge, coal, bark, ASR and mixed wastes has been dealt with in various publications [28-32].

CFBCs have been used for the thermal destruction of hazardous wastes [33] even as a mixture of slurries and solids. They are able to destroy over $99.9 \%$ of industrial waste at $1363 \mathrm{~K}$ with a 2 seconds residence time [34]. Rickman et al. [34] further reported that these incinerators can burn a variety of wastes in the presence of dry limestone to control acid gases without costly wet scrubbers and associated additional costly waste. They concluded that CFB waste incinerators are simple in their design as they use high turbulence in the reaction zone to eliminate afterburners, scrubbers or multiple feeders while providing excellent combustion efficiencies. Other benefits include autothermal operation, $\mathrm{HCl}$-capture in excess of $99 \%$, waste volume reductions up to a ratio of $40: 1$, while emissions of $\mathrm{NO}_{x}$ and $\mathrm{CO}$ can be below 100 ppmv.

In recent years, CFBC plants using coal or biomass have become established in the capacity range from 250 to $350 \mathrm{MW}_{\mathrm{el}}[35]$. A further capacity increase up to $600 \mathrm{MW}_{\mathrm{el}}$ is expected. The introduction of supercritical steam boilers further improves the energy recovery efficiency and reduces $\mathrm{CO}_{2}$ emissions [35].

An environmental application of CFBs, connected to combustors and incinerators, is the desulphurisation of flue gases. Introduced by Lurgi in the early eighties, over 100 plants are in commercial operation worldwide [36-48]. The semi-dry process is based on the conversion of calcium hydroxide with $\mathrm{SO}_{2}$ to calcium sulfite and calcium sulfate. Based on the efficiency of current industrial scale CFB desulfurisation processes, Leuschke et al. [39] have shown that it is possible to achieve 
desulfurisation efficiencies in excess of $99 \%$, reducing residual $\mathrm{SO}_{2}$ emissions to about $50 \mathrm{mg} / \mathrm{Nm}^{3}$.

As illustrated in the Figures 2 to 5 , the fluidized beds are the combustors and hold the bed material: they are the key part of the total plant, the remaining parts being the heat recovery and flue gas de-pollution stages. In general, in WtE the hot combustion gas is used to produce steam in the boiler, commonly in a superheater-boilereconomizer arrangement.. The remaining heat of the flue gas, after steam production, is used to preheat the water in an economizer. The produced steam can have various thermal applications, internally or externally, or can be used to generate electricity.

BFBC applications are illustrated in Figures 2 and 3. A typical RFBC application is shown in Figure 4, whereas a CFBC is the central part of the unit of Figure 5.

Figure 2 depicts a BFBC for waste water treatment sludge: the feed consists of 2.5 ton/h of dry solids (DS), fed at an average moisture content of $65 \%$. The bed is operated at $800-830{ }^{\circ} \mathrm{C}$ with a superficial gas velocity of 2.2 to $2.5 \mathrm{~m} / \mathrm{s}$. Here, the hot combustion gas indirectly preheats the primary combustion air (number 4 of Figure 2) [40].

The plant of Figure 3 burns automotive shredder residue (ASR): Nissan modified a BFBC at its Oppama plant to recover energy from ASR [41]. Full-scale incineration of 4800 ton/year of ASR along with other waste from Nissan plants started in 2005. The generated heat is recovered in a steam boiler; the steam is used as energy carrier in the production process e.g. for paint baking and for general heating.

Figure 4 shows a typical Ebara-Lurgi RFBC, burning 100,000 ton/year of solids derived fuel (SDF) and other waste streams (such as sewage sludge, or ASR) [28]. 
The RFBC is operated at a temperature of $850^{\circ} \mathrm{C}$. Also in this installation, WtE is achieved by heat recovery in a steam boiler. $5 \%$ of the steam generated in the boiler is used internally. The rest of the steam is used to produce electricity, with an efficiency of around $27 \%$ [43]. In turn, almost $13 \%$ of the produced electricity is for internal use.

Figure 5 finally presents a CFBC for burning 9 ton/hr of coal, wood bark and sewage sludge. Operating data are given with the Figure. The CFBC consists of a riser where the combustion occurs, followed by a cyclone which separates solids form air allowing only very fine particles to be carried out of the system. The cyclone is fitted with a standpipe to collect solids from the cyclone and provides a solids reservoir for the re-circulation valve. This mostly non-mechanical valve controls the feed of solids back into the riser [42].

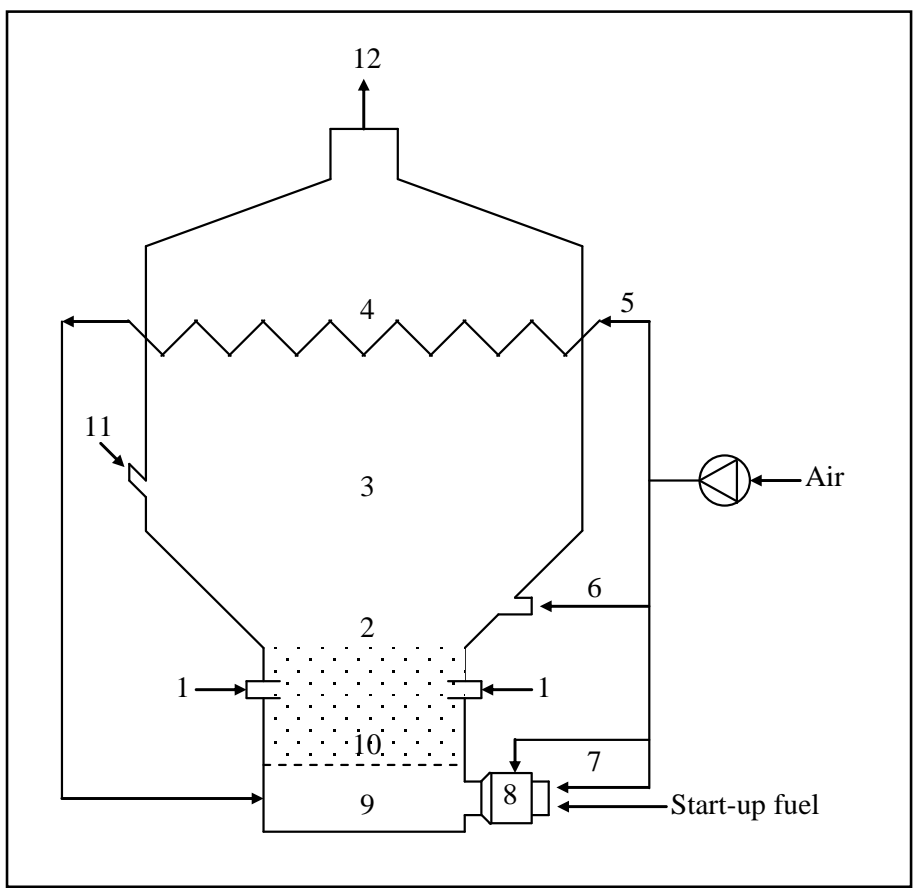

Figure 2. BFBC of sewage sludge at Brugge (Belgium) [28]

(1) sludge feed, (2) fluidized bed, (3) freeboard, (4) pre-heater of primary air, $(5,6)$ 
secondary air, (7) air to start-up burner (8), (9) windbox, (10) distributor, (11) makeup sand, (12) exhaust to further heat recovery, ESP, pollutant abatement, stack.

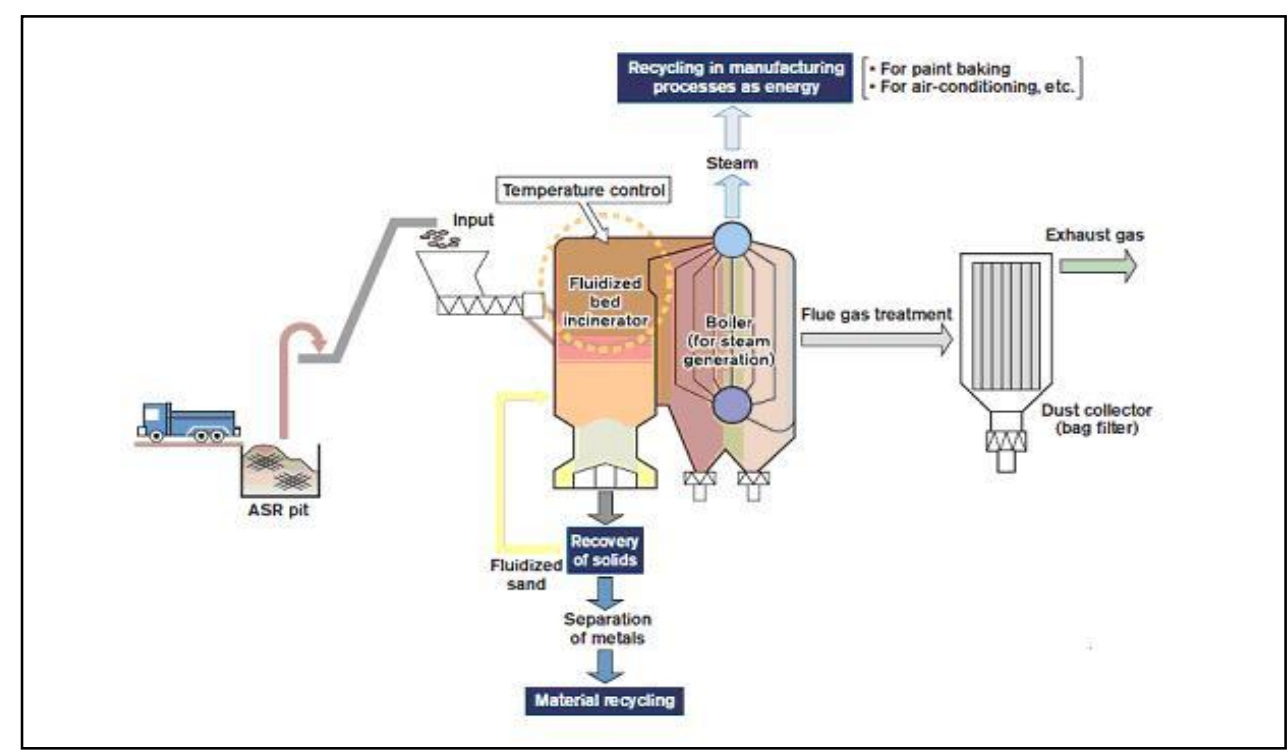

Figure 3. BFBC for ASR [29]

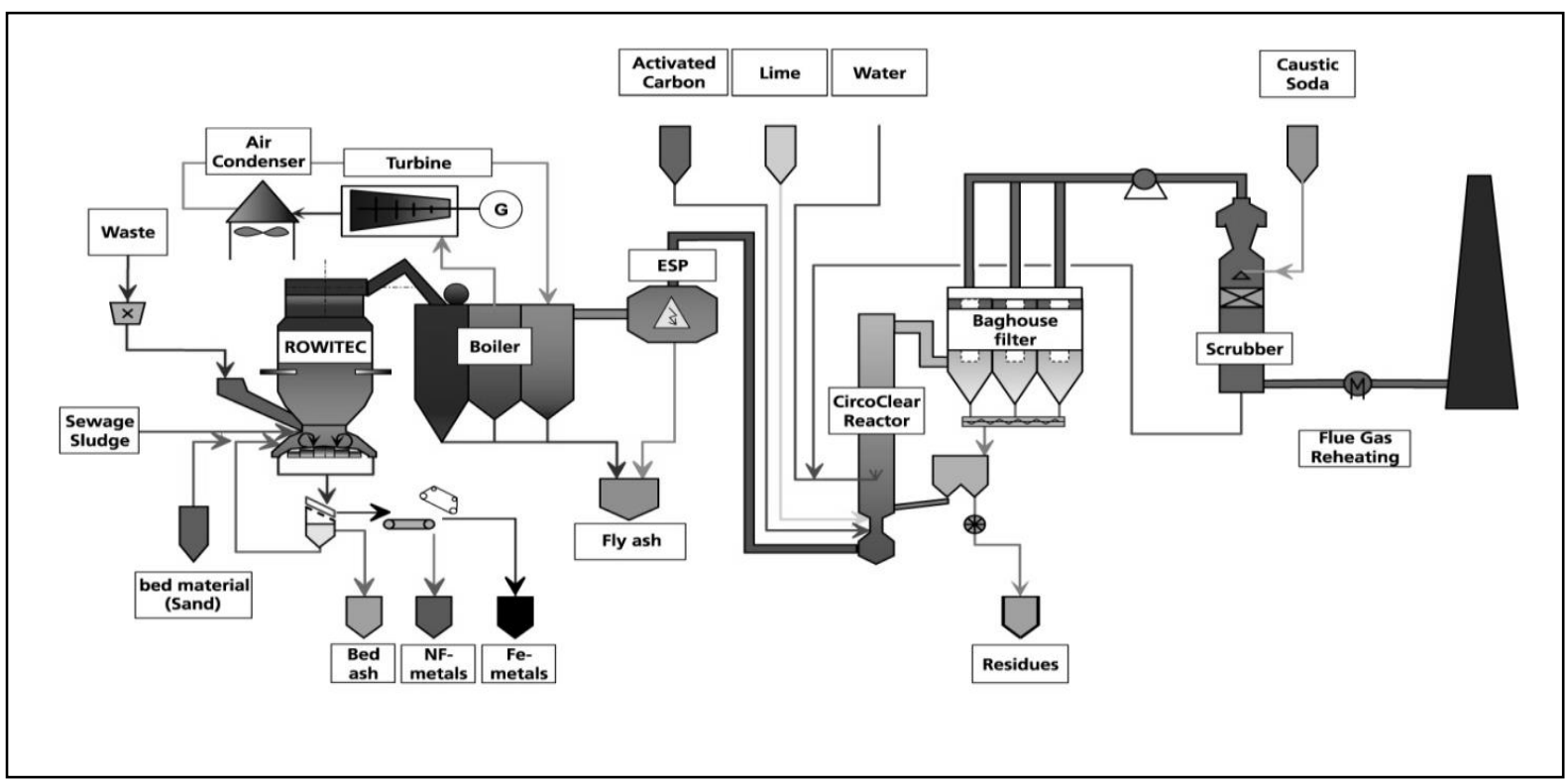

Figure 4. Ebara-Rowitec RFBC for mixed waste at Indaver, Belgium [30] 


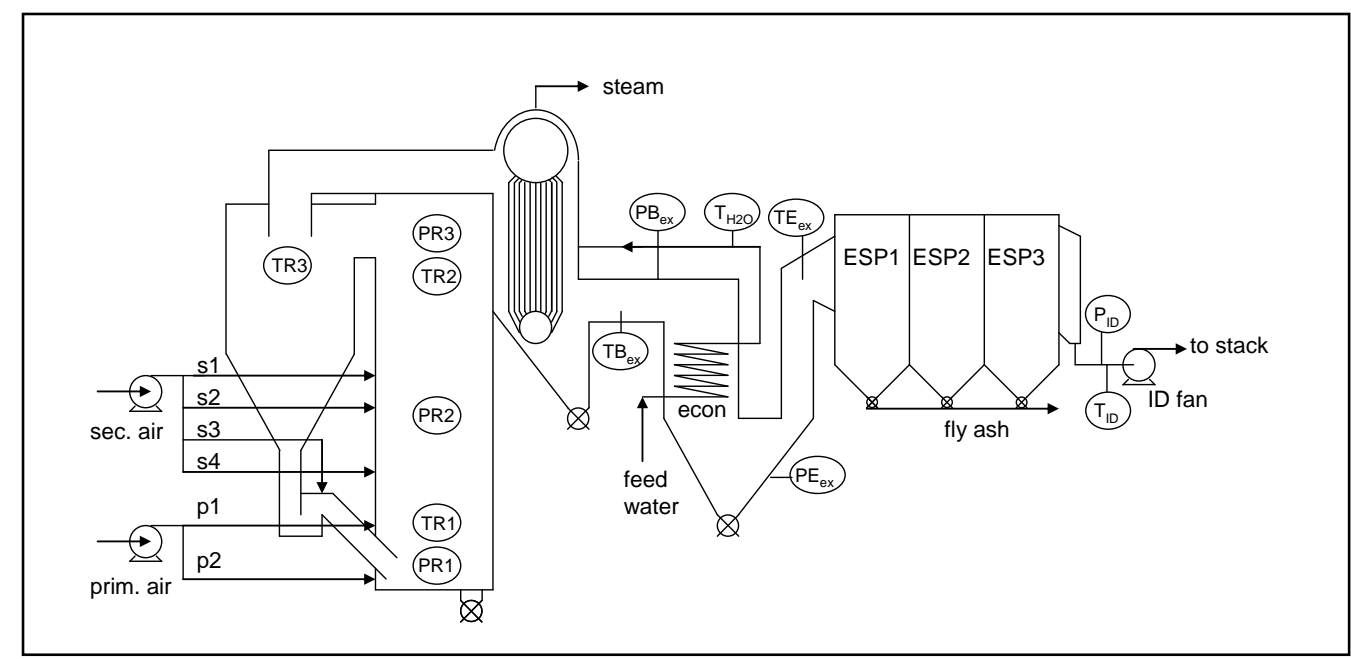

\begin{tabular}{|l|l|l|l|l|l|}
\hline \multicolumn{2}{|l|}{ Flow rate $\left(\mathrm{m}^{3} / \mathrm{s}\right)$} & \multicolumn{2}{l|}{ Pressure (mbar) } & \multicolumn{2}{l|}{ Temperature $\left({ }^{\circ} \mathrm{C}\right)$} \\
\hline S1 & 2.17 & PR1 & 189.75 & TR1 & $822-831$ \\
\hline S2 & 0.76 & PR2 & 33.37 & TR2 & $816-829$ \\
\hline S3 & 0.76 & PR3 & 1.01 & TR3 & $770-778$ \\
\hline S4 & 1.55 & PBex & -10.45 & TBex & $392-398$ \\
\hline P1 & 3.11 & PE & -24.82 & TE & $152-161$ \\
\hline P2 & 11.31 & PID & -27.64 & TID & $146-152$ \\
\hline ID fan & 17.64 & & TH2O & 208 \\
\hline
\end{tabular}

Figure 5. CFBC at Caledonian Paper, Ayr (U.K.) [31]

In BFBC and RBFC applications, the superficial gas velocity $(U)$ is the dominant parameter [21]. In a CFBC application, both solid circulation flux (G) and superficial gas velocity of the riser $(U)$ determine the operational hydrodynamics [22]. Design values for these operating parameters will be provided in Section 2.

Other thermal applications of the BFB and CFB principles, outside the scope of the present review paper, include the gasification and pyrolysis of e.g. biomass, plastic solid waste and RDF. Some additional references of CFBC applications are summarized in Table 2. 
Table 2. CFB applications [27,43-44]

\begin{tabular}{|l|l|}
\hline Reactions & References \\
\hline Combustion of coal, wood, biomass & {$[28,38,45,46-52]$} \\
\hline Waste incineration & {$[28,36-37,53]$} \\
\hline
\end{tabular}

\subsection{Objectives of the review paper}

Due to the increasing importance of fluidized bed incineration within the thermal treatment technologies presented in Sections 1.2 and 1.3, with technical information spread throughout literature, the present review paper critically examines the parameters that govern the design and operation of fluidized bed waste combustors.

Section 2 provides the reader with the design strategy of a fluidised bed combustor, involving considerations of hydrodynamic (velocities, mixing), thermal (heat balances) and kinetic (reaction rate and burn-out) nature.

Combustion of waste is associated with the emission of pollutants and produces residues. As reducing atmospheric emissions below the emission limits is often considered an important aspect of incineration, Section 3 reviews the emission problems both towards their fate and extent, and towards the current air pollution control strategies. The fate of the residues is also discussed.

Fluidized bed incineration of waste materials moreover faces problems of defluidization, due to agglomeration and sintering. Section 4 discusses the mechanisms of agglomeration and possible remedies. Additionally, important issues of equipment erosion and uniform feeding of the waste into the fluidized bed reactor are considered.

Section 5 summarizes all essential findings and provides the reader with essential recommendations towards design and/or operation. 


\section{Design strategy of FBCs}

\subsection{General design strategy}

Since Fluidized bed combustors involve a bed of inert material (sand, ash, ...), primary and secondary combustion air, a waste feed of varying composition and consistence according to the source, and the possible evaporation of water in the case of a wet feed, the design needs to account for these various inputs and is performed according to a set strategy, as illustrated in Figure 6. The different stages of the design procedure are to a large extent similar for BFBC, RFBC and CFBC, although specific considerations apply to either of these FBC's in particular. The strategy of Figure 6 therefore sidesteps for specific considerations. The different steps are discussed hereafter. 


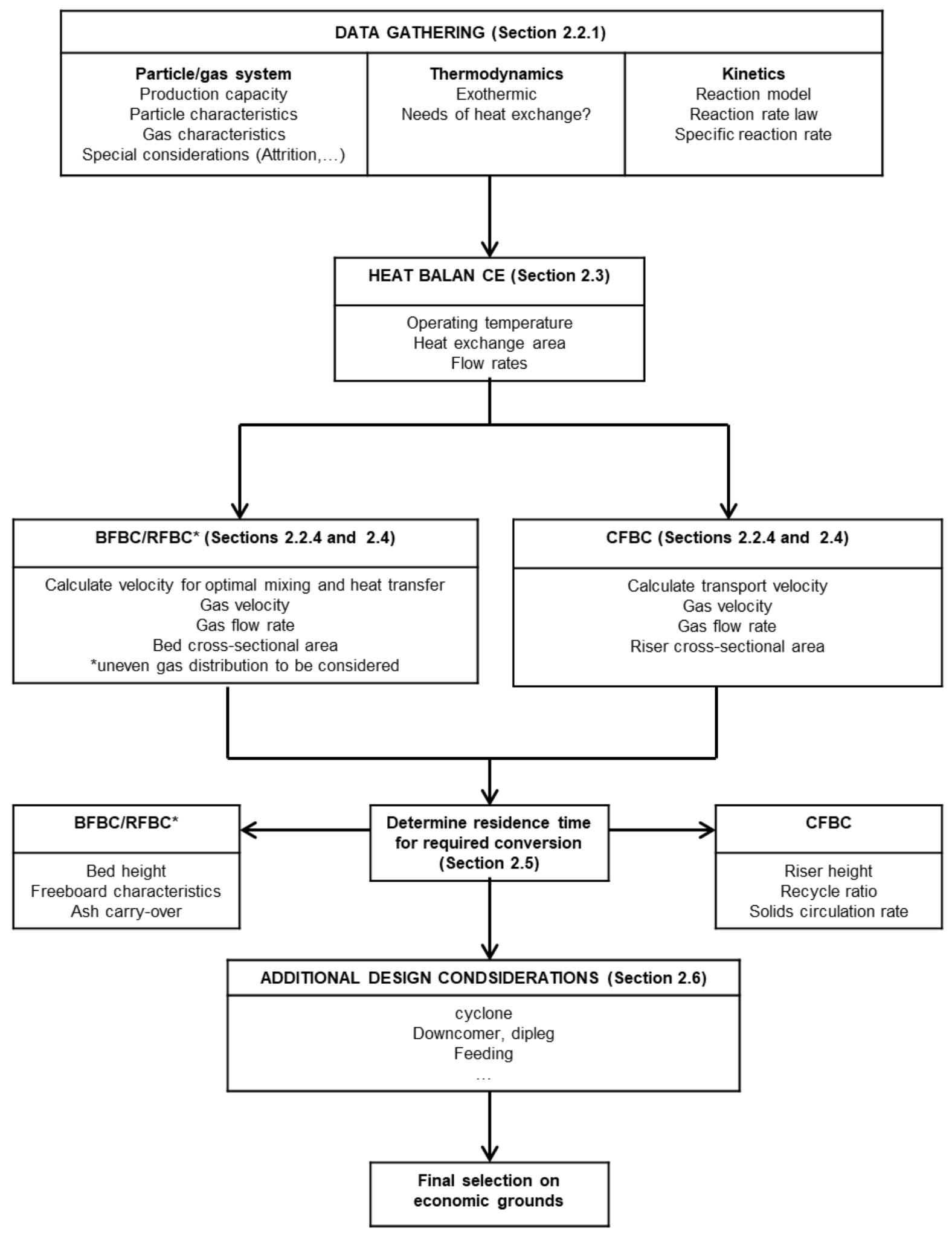

Figure 6. Design strategy of fluidized bed combustors 


\subsection{Data gathering}

\subsubsection{Properties of solid or liquid wastes}

As previously highlighted, FBCs guarantee the efficient combustion of wastes with different compositions and characteristics such as moisture content, heating value, ash content and density [55-56]. Combustion or co-combustion experiments have been reported for many waste types, including MSW, RDF from mechanical biological treatment (MBT) of MSW, sludge from wastewater treatment, biomass including agro-wastes, wood, pulp and paper waste, plastic waste and special industrial wastes such as ASR.

The properties of the solid or liquid wastes are important to evaluate alternative process flow sheets and equipment needs. These properties include the identification of the individual components that make up industrial or domestic wastes, the densities and moisture content of the wastes, and their proximate and ultimate composition. Although a wide range of waste components can be dealt with in a FBC, the lists below have been chosen as being readily identifiable and adequate for characterizing the wastes for most applications (Tables 3 and 4). With waste segregation applied in several countries (glass, paper, plastics, etc.), some classes will vary widely according to the origin. The densities and moisture content (Table 3) of the different wastes vary markedly with geographic location, season of the year, and length of storage time. Automotive shredder residue is not added in the tables below, since its characteristics vary widely with composition, particle size, possible pre-treatment, etc. [32]. 
Refuse derived fuel (RDF) has a higher heating value and better combustion performance than MSW due to a series of pre-treatment processes, such as size reduction, separation, drying and densification [59].

In general, the bulk composition of biomass in terms of carbon, hydrogen, and oxygen $(\mathrm{CHO})$ does not differ much among different biomass sources. As can be seen from Table 4, typical dry weight percentages for $\mathrm{C}, \mathrm{H}$, and $\mathrm{O}$ are 30 to $60 \%, 5$ to $6 \%$, and 30 to $45 \%$ respectively. Nitrogen, sulfur and chlorine can also be found in dry weight percentages below $1 \%$. Compared to coal, biomass generally has less carbon, more oxygen, more silica, chlorine and potassium, less aluminum, iron, titanium and sulfur, and sometimes more calcium.

In many FBCs, different waste types and/or conventional fossil fuels are mixed in a ratio depending on their chemical composition, physical properties (e.g. state of aggregation) and thermal characteristics (e.g. heating value and moisture content), in order to reach high combustion efficiency and steady combustion characteristics [6061]. A large number of papers discuss the co-incineration of MSW, RDF or biomass in existing coal fired FBCs for energy production $[55,60,57,62-76]$. One of the advantages of this form of co-incineration is that the waste can be energetically valorized without high investment costs. Furthermore, as the carbon in MSW, RDF and biomass is up to $100 \%$ of biogenic origin, the net $\mathrm{CO}_{2}$ emission per unit of energy produced decreases compared to coal combustion $[57,59,61,63,66,69$, 73]. Due to the different composition and combustion characteristics of MSW, RDF or biomass and coal (Table 4), the emission of certain pollutants during co-combustion can change significantly compared to pure coal combustion $[77,64,60,69,72,75$ 76]. This will be discussed in more detail in Section 3. 
Table 3. Density and moisture content for domestic, commercial and industrial solid waste [27]

\begin{tabular}{|l|l|l|l|l|}
\hline & \multicolumn{2}{l|}{$\begin{array}{l}\text { density } \\
\text { (kg/m } \mathbf{m}^{3}\end{array}$} & \multicolumn{2}{l|}{$\begin{array}{l}\text { moisture content } \\
\text { (\% by mass) }\end{array}$} \\
\hline item & range & typical & range & Typical \\
\hline & & & & \\
LOOSE RESIDENTIAL WASTE & & & & \\
food waste (mixed) & $130-480$ & 290 & $50-80$ & 70 \\
paper & $40-130$ & 85 & $4-10$ & 6 \\
cardboard & $40-80$ & 50 & $4-8$ & 6 \\
plastics & $40-130$ & 65 & $1-4$ & 2 \\
rubber & $100-200$ & 130 & $1-4$ & 2 \\
garden trimmings & $60-225$ & 100 & $30-80$ & 60 \\
wood & $130-320$ & 240 & $15-40$ & 20 \\
dirt, ashes, etc. & $320-1000$ & 450 & $6-12$ & 8 \\
ashes & $650-830$ & 745 & $6-12$ & 6 \\
MSW (mixed) & $90-180$ & 130 & $5-20$ & 15 \\
waste water treatment sludge & $1000-1050$ & 1030 & $50-75$ & 35 \\
& & & & \\
COMMERCIAL WASTE & & & & \\
food wastes (wet) & $475-950$ & 535 & $5-85$ & 75 \\
wooden crates & $110-160$ & 110 & $10-30$ & 20 \\
tree trimmings & $100-180$ & 150 & $20-80$ & 30 \\
INDUSTRIAL WASTE & & & & \\
chemical sludge (wet) & $800-1100$ & 1000 & $75-99$ & 80 \\
fly ash & $700-900$ & 800 & $2-10$ & 4 \\
oils, tars, asphalts & $800-1000$ & 950 & $0-5$ & 2 \\
sawdust & $100-350$ & 290 & $10-40$ & 15 \\
textile wastes & $100-220$ & 180 & $6-15$ & 10 \\
wood (mixed) & $400-675$ & 500 & $10-40$ & 20 \\
& & & & \\
AGRICULTURAL WASTE & & & & \\
agricultural (mixed) & $400-750$ & 360 & $40-80$ & 50 \\
fruit wastes (mixed) & $250-750$ & 360 & $60-90$ & 75 \\
manure (wet) & $900-1050$ & 1000 & $75-96$ & 94 \\
vegetable wastes (mixed) & $200-700$ & 360 & $50-80$ & 65 \\
\hline
\end{tabular}

The proximate and ultimate analysis determines the energy content and combustion characteristics of the waste streams. Approximate values are given in Table 4 below. The approximate values of the energy content on a dry basis (db), can be determined from the proximate analysis using a modified Dulong formula $[42,50]$ : 
$k J / k g=337 C+1428\left(H-\frac{1}{8} O\right)+95 S$

with $\mathrm{C}, \mathrm{H}, \mathrm{O}$ and $\mathrm{S}$ the wt\% of the elements.

Table 4. Typical ultimate-analysis data for components in domestic, commercial and industrial solid waste $[27,59,76]$

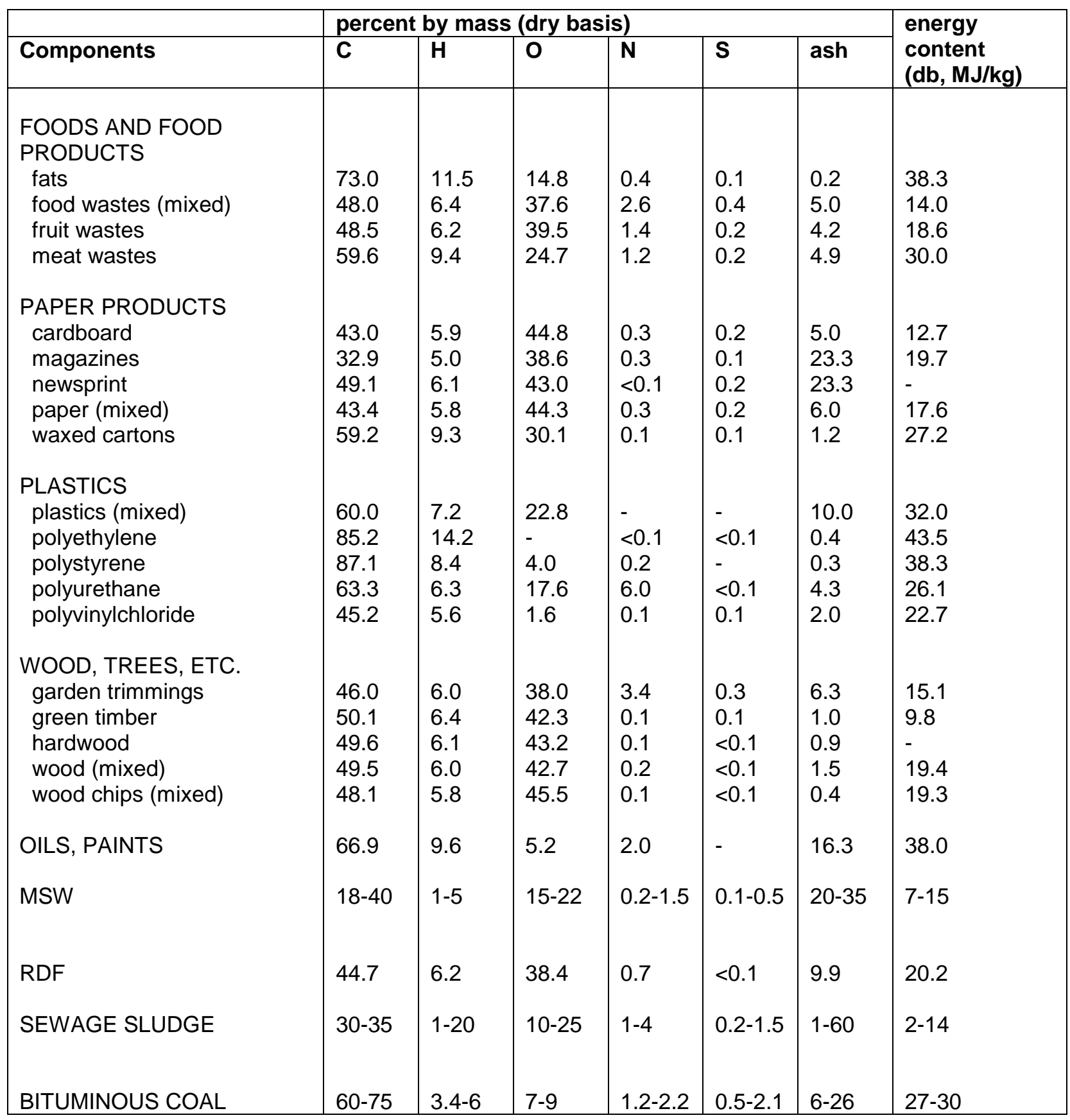


A specific waste commonly burned in a FBC is wastewater treatment sludge, with high contents of water and minerals. Sludge varies considerably both in dry solids (DS) concentration (5-20\% for refinery sludge, $15-40 \%$ for dewatered sewage sludge), and the percent combustibles (50-75\% of dry solids) and consequently the calorific values vary [30]. Depending on the composition of combustibles, the desired operating temperature and the amount of heat recovery achieved, the minimum solids concentration required for auto-thermal operation is fixed. This will be illustrated in Section 2.3 for typical commercial applications. For municipal sewage sludge, various studies, reported by Baeyens and Van Puyvelde [30], have shown that the composition of the organic matter averages to $\left(\mathrm{CH}_{1.65} \mathrm{O}_{0.34} \mathrm{~N}_{0.1}\right) \mathrm{m}$. Depending on the ash content, the calorific value lies between 4000 and $22000 \mathrm{~kJ} / \mathrm{kg}$ DS. The calorific value of digested sludge is $15 \%$ lower due to a higher fraction of minerals being present.

\subsubsection{Essential data of the FBC}

Particle characteristics include particle size distribution and average size, absolute and bulk density, and specific heat. Important gas characteristics include gas density, viscosity and specific heat, which are all temperature dependent. Moreover, the composition of the combustion gas mixture is also an important parameter in combustor design. The reaction kinetics and thermodynamics can be defined by literature data or by experimental work.

For BFBCs and RFBCs, particle sizes of the bed material are in the range of $0.5-3$ $\mathrm{mm}$. At start-up, the combustors use sand $\left(\rho_{p}=2600 \mathrm{~kg} / \mathrm{m}^{3}\right)$, which is gradually supplemented and replaced by combustion ash $\left(\rho_{p}=2200\right.$ to $\left.2500 \mathrm{~kg} / \mathrm{m}^{3}\right)$. The bed characteristics should therefore relate to ash, rather than to sand. 
CFBCs are also operated with an inert (sand/ash) bed. The average particle size in a CFBC is around $200-300 \mu \mathrm{m}$.

The dominant operating parameter in bubbling bed fluidization is the gas velocity. In circulating fluidized beds, both the gas velocity and the solids circulation flux are important.

Figure 7 is adapted from [78-79], with representative values of the major characteristic parameters. $U_{m f}$ is the minimum fluidization velocity, $U_{c}$ the velocity of transition from bubbling to turbulent fluidization and UTR is the onset velocity of the circulating fluidized bed mode.

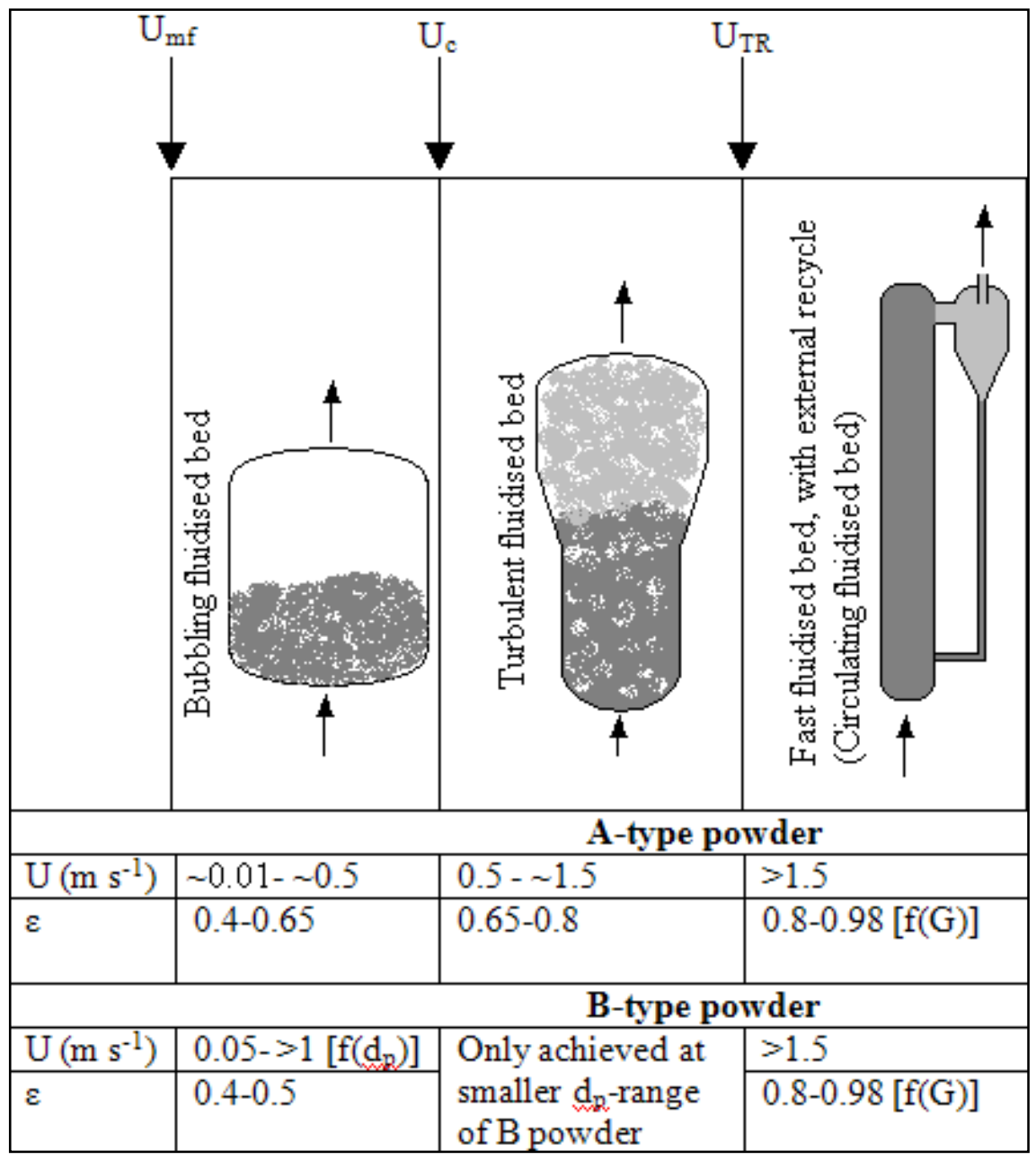

Figure 7. Characteristics of various fluidization regimes 
Table 5 presents a few empirical equations to predict the regime transition velocity, Utrans.

Table 5. Transition velocities

\begin{tabular}{|l|lr|l|}
\hline$U_{\text {trans }}$ & Equation & Value $^{(\mathrm{a})}(\mathrm{m} / \mathbf{s})$ \\
\hline$U_{m f}$ & $A r=1823 \operatorname{Re}_{m f}^{1.07}+21.27 R e_{m f}^{2}$ & {$[79]$} & 0.009 \\
\hline$U_{C}$ & $R e_{c}=1.24 A r^{0.45}$ for $2<\mathrm{Ar}<10^{8}$ & {$[80]$} & 1.33 \\
\hline$U_{T R}$ & $R e_{T R}=1.53 A r^{0.5}$ & {$[81]$} & 2.05 \\
\hline
\end{tabular}

(a) For a $100 \mu \mathrm{m}$ particle of $\rho_{p}=2600 \mathrm{~kg} / \mathrm{m}^{3}$

It should be remembered that $\mathrm{Ar}$ and Re represent respectively the Archimedes and Reynolds-number for the particle-gas system, as defined in the Nomenclature. In both dimensionless numbers, particle properties (size and density) and gas properties (density and viscosity) are grouped.

A bubbling fluidized bed operates at velocities well in excess of the minimum fluidization velocity. Optimum mixing in the bed and maximum heat transfer are achieved within specific velocity limits that are function of the particle size of the bed material [21]. These operating velocity ranges are given in Figure $8, U_{\min }$ representing the minimum gas velocity, and $\mathrm{U}_{\max }$ the maximum velocity required to achieve good mixing and heat transfer. The Figure moreover includes a few illustrations of commercial applications: each pair of velocities corresponds to flow with and without the evaporation of water and corresponds roughly to the velocities at the distributor and at the top of the bed respectively. Most beds operate well above $U_{\min }$ in order to reduce the bed diameter, but this velocity needs also to consider particle entrainment and required complete burn-out of entrained waste particles. 


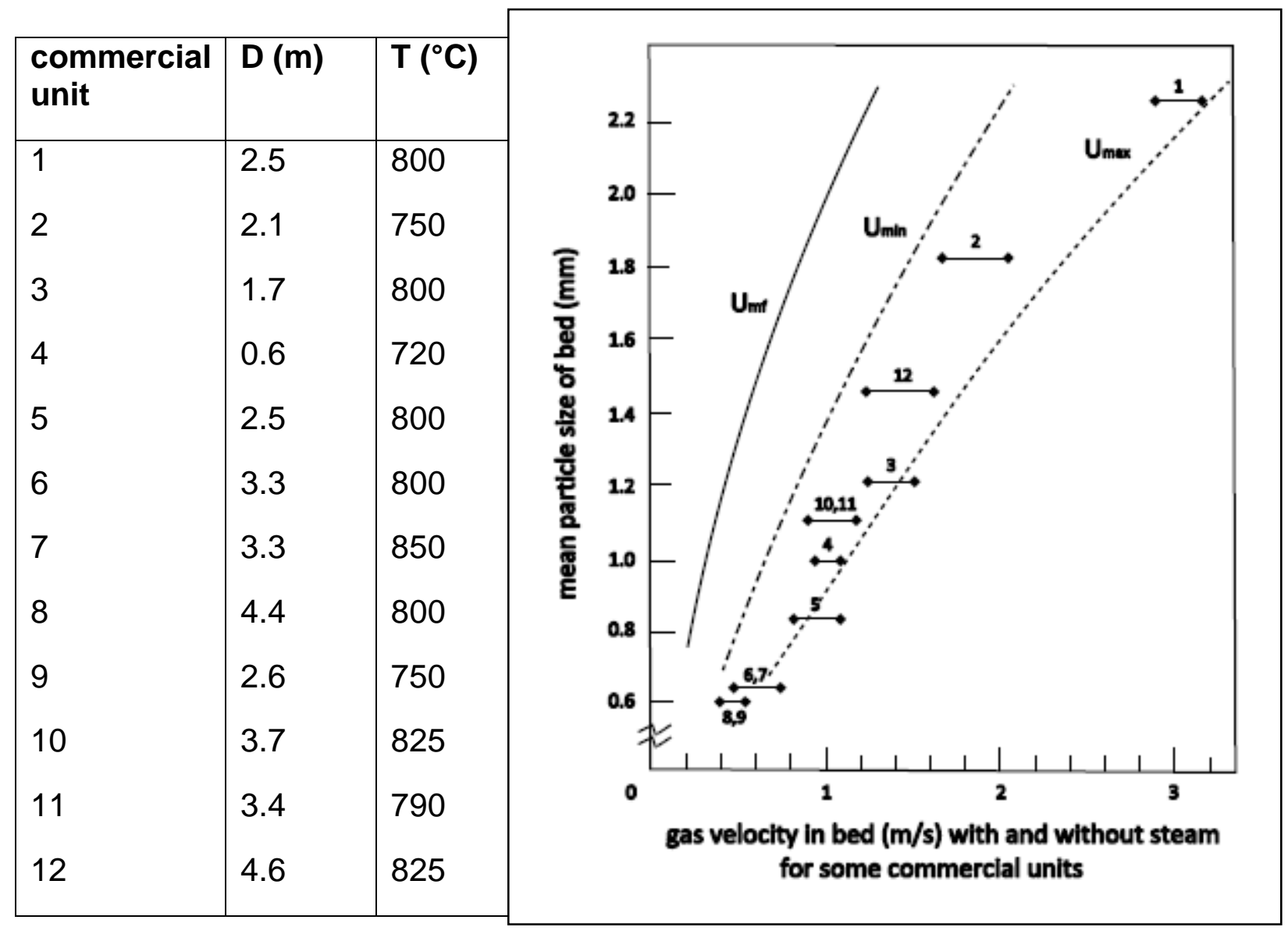

Figure 8. Optimum mixing velocity limits

For RFBCs, the operating velocity is no longer uniform throughout the cross-sectional area of the fluidized bed: the central part of the air distributor is fed with an excess air flow of about $20 \%$, thereby creating a deliberate mal-distribution and imposed solids circulation from the centre of the bed to the wall area. This is illustrated in work by Whitehead and Dent [83].

A circulating fluidized bed riser operates at high velocities and with an external circulation of bed material. Gas and solids are close in temperature due to the high inter-phase heat transfer rates. The temperature profile along the length of the riser is uniform for reactions of low energy change [84] and the types and rates of chemical reactions thus taking place (which are temperature dependent) can also be easily 
and uniformly controlled. A stable CFB-operation requires external solids circulation and is only possible at velocities in excess of the transport velocity UTR. Van de Velden et al. [44-45] demonstrated that the equation in Table 5, derived by Bi and Grace [82], provides a fair prediction of UTR for a wide variety of powders. The accuracy is expected to be about $10 \%$, so that it is recommended to operate the riser at a velocity in excess of UTR. Most of the CFBCs operate at 3-9 m/s as velocity range, with $40-90 \mathrm{~kg} / \mathrm{m}^{2} \mathrm{~s}$ as solid circulation flux [22].

\subsection{Heat balance, net energy yield and flow rates}

A heat balance over the FBC determines the net energy yield. At sufficient excess gas velocity (BFBC) and circulation rates (CFBC) the bed can be assumed isothermal [84-85]. Considerations of the reaction kinetics and heat exchange aspects result in an optimum temperature.

For waste with a high calorific value, such as RDF, biomass, ASR, plastic solid waste, there is normally an excess of heat generated in the combustor. To maintain the bed at its operating temperature, systems for the removal of heat have to be chosen and the exchange surface area has to be determined for imbedded tubes or for a wall-mounted jacket. Once the operating temperature is known, the temperature dependent gas properties in the FBC can be determined. The stoichiometry enables to calculate the air requirements for complete combustion allowing for approximately $20 \%$ excess air. In general $80 \%$ of the total air is introduced through the windbox (primary air) and $20 \%$ into the freeboard of the BFBC, or higher up the riser of a CFBC (secondary air).

For waste with a low calorific value, such as mechanically dewatered municipal sewage sludge, autothermal operation generally requires the pre-heating of the 
fluidization air, and/or a pre-drying of the wet sludge feed. Figure 9 illustrates the heat balance including heat recovery in the case of such a wet feed. The relative amounts of heat input into the air and/or sludge can be determined. The possible pre-drying of the sludge has moreover consequences on the pumping or handling properties of the sludge at various concentrations: the lower limit for readily pumpable sewage sludge is between 80 and $90 \%$ water. Sludge of any sort with less than $80 \%$ water generally has to be fed by screw conveyor or slinger.

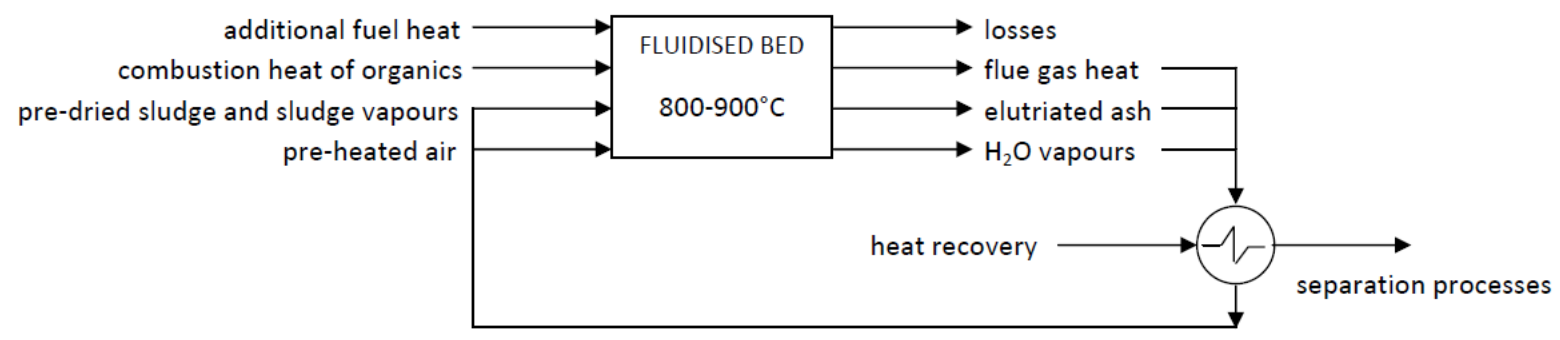

Figure 9. Heat balance [33]

The volumetric flow rate of primary and secondary air, as well as the total exhaust gas volume throughout the combustor, including water vapour, can now be calculated. Special burners are often used at start up to increase the volumetric flow rate of gas because the fan is often not large enough to fluidise the bed with cold air.

An example of the heat balance for the BFBC of sewage sludge is given in Figure 10. It appears that the percentage dry solids in the raw sludge feed determines the range of auto-thermal operation. With enhanced heat recovery, the $\%$ dry solids in the feed can be considerably reduced and coincides with the achievable dry solids content of mechanically dewatered sludge (> 25 wt\% DS). 


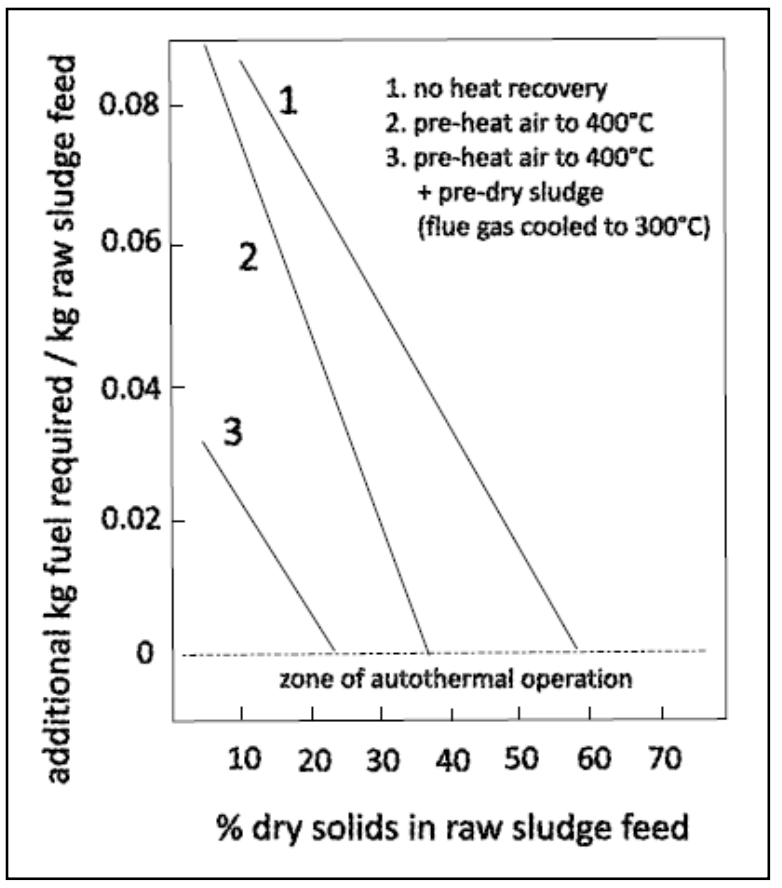

Figure 10. Amount of additional fuel (38 MJ/kg) required for combustion of sewage sludge with heating value $8900 \mathrm{~kJ} / \mathrm{kg}$ dry solids, combustible concentration $50 \%$ of dry solids, temperature $800^{\circ} \mathrm{C}$, excess air $20 \%$

\subsection{Operating gas velocity and cross sectional area of the combustor}

Generally, the inert bed material is quartz sand in the size range of $0.6-3 \mathrm{~mm}$ for a BFBC and RFBC. Coarse particles are used only because they have higher terminal and incipient fluidization velocities, but also because they are less affected by stickiness due to fewer inter-particle contacts and greater particle momentum, which breaks incipient bonds. Agglomeration of bed material can indeed occur [30] when chemical sludge is treated, or whenever salt concentrations are high: this will be discussed in detail in Section 4. Common operating velocities are associated with rapid solids mixing and are only achieved within the previously defined gas velocities between $U_{\min }$ and $U_{\max }$, as illustrated in Figure 8. The total gas flow within the BFBC and the selected operating velocity (at operating temperature) then fix the required cross sectional area of the BFBC. 
In a CFBC, superficial gas velocities are higher $(3-9 \mathrm{~m} / \mathrm{s})$ although the bed material has a smaller size $(0.1-0.3 \mathrm{~mm})$ than in a BFBC. Temperatures are in the same order of magnitude, and attention to agglomeration remains the same, although agglomeration is slightly less important due to the high shear rate achieved. Solids circulation fluxes are between 40 and $90 \mathrm{~kg} / \mathrm{m}^{2} \mathrm{~s}$. Again, total gas flow and selected operating velocity define the cross sectional area of the CFBC.

For a RFBC, the uneven distribution of the fluidization air, will induce a significant internal solids circulation (hence the name rotating fluidized bed), providing better mixing of the feed particles within the bed material. No general design rules can be given.

Once the volumetric flow of the fluidisation air and of the total exhaust gas volume have been determined from the considerations of Section 2.3, and the operating gas velocity has been selected for either bubbling or circulating fluidization mode, the required cross-sectional area of the $\mathrm{BFBC}$ or $\mathrm{CFBC}$ is determined by the ratio of the volumetric flow rate of the exhaust gas volume and the operating velocity.

\subsection{Combustion kinetics and required residence time}

To determine the required residence time of the waste feed into the FBC, combustion kinetics need to be considered. In the combustor, de-volatilisation and combustion of volatiles and char take place. Release of vapour from the waste particle core cools the particle's surface and keeps its temperature low, so that it can be assumed that char combustion starts only after de-volatilisation is completed.

Boroduyla et al. [86] investigated the combustion of wood particles $\left(d_{p}=3.5-21.5\right.$ $\mathrm{mm}$ ) in a fluidized bed of sand particles at temperatures from 750 to $850^{\circ} \mathrm{C}$. The particle size was found to decrease insignificantly during drying and de-volatilisation, 
with these processes mainly coinciding in time. Furthermore, the volatile extinction time of wood i.e. the time needed to completely evolve volatile components, can be estimated from:

$$
t_{v o}=12000 d_{p}^{1.3}
$$

with tro in seconds and $d_{p}$ in $\mathrm{m}$.

To calculate the burnout time of char particles, a reaction model is required. With the assumptions that the reaction is mass transfer limited and that it occurs in two successive steps with $\mathrm{CO}$ as intermediate, the burnout time tch for a char particle can be theoretically derived as [50]:

$$
t_{c h}=\frac{\rho_{M} R_{o}^{2}}{4 D_{O_{2}} C_{O_{2}}}
$$

When waste particles are introduced in the BFBC, they stay in the bottom part of the bed, considered as the dense bed, until their terminal velocity becomes small enough to carry them up the freeboard with the gas stream. The transport of large particles in the riser occurs not only due to the drag force of the gas, but also due to the impact of the fine sand particles on the large waste particles.

The terminal velocity, $\bigcup_{t}$, can be calculated as first approximation from the relationship between the particle-gas Archimedes number, Ar, and the Reynolds number at the terminal velocity, $\operatorname{Re}_{t}[30]$ :

$$
A r=18 R e_{t}+0.33 R e_{t}^{2}
$$


Illustration of the characteristic design parameters is given below. The terminal velocity at $850^{\circ} \mathrm{C}$ for different combinations of particle sizes and densities is given in Table 6.

Table 6. Terminal velocities

\begin{tabular}{|l|l|l|l|l|l|l|}
\hline $\boldsymbol{d}_{p}(\mathbf{c m})$ & 0.1 & 0.5 & 1 & 1.1 & 1.5 & 2 \\
\hline $\boldsymbol{\rho}_{p}\left(\mathbf{k g} / \mathbf{m}^{3}\right)$ & 600 & 600 & 600 & 600 & 420 & 290 \\
$\boldsymbol{U}_{\boldsymbol{t}}(\mathbf{m} / \mathbf{s})$ & 1.5 & 4.9 & 7.5 & 7.9 & 7.9 & 7.9 \\
\hline
\end{tabular}

The required time for de-volatilisation and the burnout time of the char particles can be calculated from equations (2) and (5) respectively. When using $20 \%$ excess fluidization air, the concentration of $\mathrm{O}_{2}$ varies through the riser from $1.03 \mathrm{~mol} / \mathrm{m}^{3}$ after combustion of the volatiles to $0.296 \mathrm{~mol} / \mathrm{m}^{3}$ in the flue gases. The concentration of $\mathrm{O}_{2}$ is assumed to vary linearly during the char combustion. Results are given in Table 7.

Table 7. Theoretical reaction times for waste feed particles of size $d_{p}$

\begin{tabular}{|l|l|l|l|l|l|l|}
\hline $\boldsymbol{d}_{\boldsymbol{p}}(\boldsymbol{c m})$ & 0.1 & 0.5 & 1 & 1.1 & 1.5 & 2 \\
\hline $\boldsymbol{t}_{\text {vo }}(\boldsymbol{s})$ & 1.51 & 12.3 & 30 & 34 & 51 & 74 \\
$\boldsymbol{t}_{c h}(\boldsymbol{s})$ & 2.26 & 56.5 & 226 & 273 & 508 & 904 \\
$\boldsymbol{t}_{\text {total }}(\boldsymbol{s})$ & 3.77 & 68.7 & 256 & 307 & 559 & 978 \\
\hline
\end{tabular}

Clearly, for smaller waste particles as used in a CFBC, de-volatilisation and char combustion times are comparable, and very short. In a BFBC, normally using coarser feed particles, the char combustion determines the overall required residence time. The impact of the required residence time on the height of a BFBC is reflected in the bed volume (and hence bed height, since the cross-sectional area is fixed by the gas flow rate). Commercial FBCs operate with be heights of 0.5 to $0.6 \mathrm{~m}$ [30], which represents a compromise between the need to minimize the compressor power whilst 
providing a sufficient residence time for the combustion. In a CFBC, the circulation loop offers an additional degree of flexibility and the required residence time reflects itself in a combination of solids circulation flux, cyclone efficiency and riser height [50].

The treatment presented above offers a simplified design approach, applicable as a first approximation and with reasonable engineering design accuracy. A more complete review of the combustion kinetics is given by Lanauze et al. [87].

\subsection{Additional design considerations}

\subsubsection{The freeboard of a BFBC}

It is common for BFBC's to have tapered bed zone to allow for the extra volume of gases produced by the evaporated water. This taper may be continued into the freeboard (or the freeboard diameter may be increased more sharply) to minimize the elutriation of fines. A high gas velocity in the bed gives a smaller bed diameter but leads to several disadvantages: (i) the coarse inert particles are ejected at high velocity by the bursting bubbles, and unless the freeboard is very high, some will be carried out; and (ii) the injected fines will be carried out of the bed zone rapidly, and although their residence time in the incinerator can be increased by having a large freeboard, much of the combustion would then taken place above the bed rather than in it. The design of the bubbling fluidized bed freeboard and carry-over has recently been reviewed and modelled [24]. If a considerable amount of fines is carried out of the BFBC, the freeboard height needs to be designed specifically to guarantee the complete combustion of the entrained particles. This has been previously presented by Baeyens and Geldart [88] and is summarized below. It is especially important 
when burning sewage sludge, where the sludge particles are of the order of $0-100$ $\mu \mathrm{m}$, hence prone to elutriation before complete burnout.

In the event of solids being deposited on the bed as a result of sintering, causing an increase in particle size, a solids removal system must be provided at the bottom of the bed, and the design must allow for particle growth.

Gaseous volatiles are produced during de-volatilization and these require a residence time in the freeboard of approximately 2 seconds for their destruction at $750^{\circ} \mathrm{C}$. Since freeboard velocities are usually $0.7-1 \mathrm{~m} / \mathrm{s}$, this time is always exceeded. Most municipal and water treatment sludge consist of solids $<100 \mu \mathrm{m}$ and it is the burnout of the elutriated particles which determines the height of the freeboard.

In the treatment proposed by Baeyens and Geldart [88], the burnout length L is calculated as:

$L=\frac{U_{f b} \rho_{M P}}{2 b \alpha C_{A}} d_{i}^{2}-\frac{g\left(\rho_{p}-\rho\right) \rho_{M P}}{72 \mu b C_{A} \alpha} d_{i}^{4}$

The height of the freeboard should obviously be larger than the burnout length $L$. The burnout length is a function of the gas velocity in the freeboard of the BFBC, as shown in Figure 11. Freeboard heights for various commercial incinerators are shown on the same figure for comparison, and clearly exceed the theoretical values. 


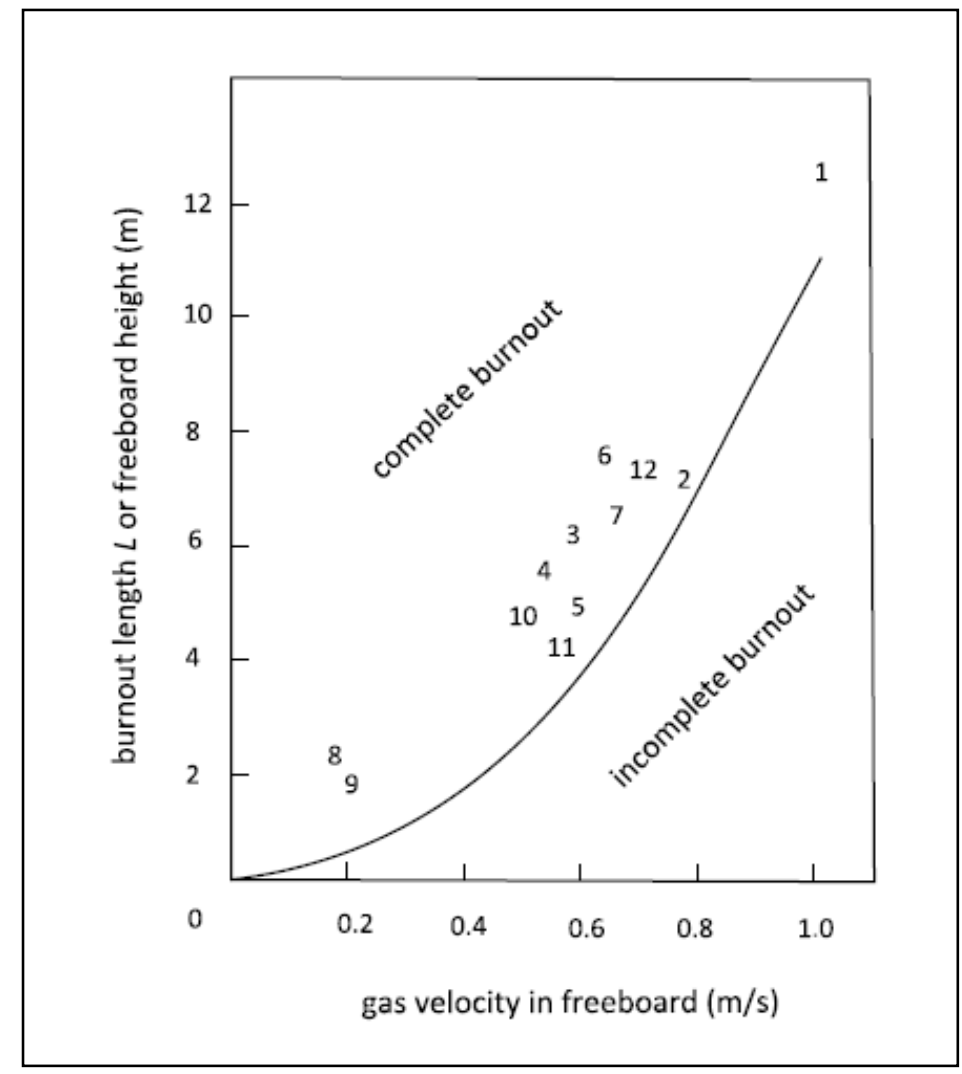

Figure 11. Theoretical burn-out length versus freeboard velocity

(numbers relate to the freeboard heights for commercial units listed in Figure 8)

\subsubsection{Additional considerations for a CFBC}

Although the waste combustion is achieved in the riser of the CFBC, the cyclone, standpipe and non-mechanical valve are essential parts of the unit and were studied in detail by various researchers with the most relevant publications listed in Table 8 . The reader is referred to these relevant references if specific design recommendations of these high temperature CFBC items are required.

For high temperature cyclones, the treatment by Dewil et al. [95] is very comprehensive and enables an accurate design approach. As far as standpipes and L-valves are concerned, appropriate design equations are included in Chan et al. [104] and Chan et al. [112]. 
Table 8. Auxiliary equipments of the CFB unit: some relevant publications

\begin{tabular}{|l|l|}
\hline Auxiliary equipment & Contributions \\
\hline Cyclones & {$[89-96]$} \\
\hline Standpipes & {$[98-105]$} \\
\hline L-valves & {$[106-113]$} \\
\hline
\end{tabular}

\section{Stack emissions: Problems and remedies}

\subsection{Generalities}

Various pollutants are emitted by a $\mathrm{FBC}$, with $\mathrm{CO}, \mathrm{HCl}, \mathrm{SO}_{x}, \mathrm{NO}_{x}$, particulate matter (dust), polychlorinated dioxins and furans (PCDD/Fs) and heavy metals being of major environmental concern. The formation of these pollutants in FBCs depends on operating conditions as well as on fuel properties [113].

Table 9 illustrates the concentrations of the main pollutants reported in stack emissions of full scale MSW incinerators equipped with adequate flue gas cleaning technology. For reasons of comparison, the emission concentration ranges for grate furnace waste incinerators and the emission limits according to the European Directive on waste incineration (Directive 2000/76/EC) are also included.

Table 9. Typical pollutant concentrations in stack emissions of MSW incinerators (daily average values in $\mathrm{mg} / \mathrm{m}^{3}$ unless otherwise stated).

\begin{tabular}{|l|l|l|l|}
\hline Pollutant & FBC [115-116] & $\begin{array}{l}\text { Grate furnace } \\
{[115,117]}\end{array}$ & $\begin{array}{l}\text { Limit values EU Directive } \\
2000 / 76 / \text { EC }\end{array}$ \\
\hline $\mathrm{CO}$ & $14-40$ & $6.0-14$ & $50^{\mathrm{a}}$ \\
$\mathrm{HCl}$ & $0.1-8$ & $0.9-6.1$ & $10^{\mathrm{a}}$ \\
$\mathrm{SO}_{x}$ as $\mathrm{SO}_{2}$ & $1-1.6$ & $1.6-10.3$ & $50^{\mathrm{a}}$ \\
$\mathrm{NO}$ as $\mathrm{NO}_{2}$ & $90-150$ & $65-145$ & $200^{\mathrm{a}}$ \\
$\mathrm{PM} 10$ & $0.6-1$ & $0.0-0.8$ & $10^{\mathrm{a}}$ \\
$\mathrm{TOC}$ & $0.9-5$ & $0.1-1.8$ & $10^{\mathrm{a}}$ \\
$\mathrm{Hg}$ & 0.013 & $<0.0005-0.013$ & $0.05^{\mathrm{b}}$ \\
$\mathrm{Cd}+\mathrm{Tl}$ & 0.0001 & $0.05^{\mathrm{b}}$ \\
$\mathrm{Sb}+\mathrm{As}+\mathrm{Pb}+\mathrm{Cr}+$ & $<0.016$ & 0.09 & $0.5^{\mathrm{b}}$ \\
$\mathrm{Co}+\mathrm{Cu}+\mathrm{Mn}+\mathrm{Ni}+\mathrm{V}$ & 0.05 & $0.001-0.01$ & \\
$\mathrm{PCDD} / \mathrm{Fs}$ & 0.008 & & $0.1^{\mathrm{c}} \mathrm{ngTEQ} / \mathrm{m}^{3}$ \\
\hline
\end{tabular}

${ }^{a}$ daily average value 
${ }^{\mathrm{b}}$ average values over a period of 6 to 8 hours

${ }^{c}$ average values over a period of 30 minutes to 8 hours

Table 9 demonstrates that the pollutant concentrations in the stack emission of full scale FBCs remain below the Directive limits. The concentrations are moreover very similar to considered stack emissions of grate furnace type MSW incinerators, which is not surprising since both types of incinerators apply similar flue gas treatment technologies.

The formation and abatement of major pollutants in flue gas of FBCs is discussed in detail in the following sections.

\subsection{Major pollutants in the flue gas}

\subsubsection{Carbon monoxide (CO)}

Carbon monoxide (CO) in the flue gas of FBCs and of incineration plants in general is the product of incomplete combustion of carbon based compounds [58]. The COconcentration in combustion gases generally increases when the proportion of biomass in the waste feed increases $[62,65,69]$. Kaynak et al. [69] reported that the CO-concentration in the raw combustion gas of a pilot scale BFBC, burning peach and apricot stones with lignite coal, increased with increasing biomass/coal ratios, due to the high volatile matter content of the fruit stones: upon feeding, the stones immediately started to release volatile matter, entrained with the gas phase resulting in a limited residence time and hence in incomplete combustion. In contrast to the previous findings, Madhiyanon et al. [73] found that the CO-concentration in the raw flue gas of a pilot scale cyclonic FBC co-incinerating rice-husk and coal decreased when the rice husk/coal ratio was increased from $75 / 25$ to $100 / 0$. The authors explain 
the decrease by the fact that coal is denser and possesses more char than rice husk and thus would require a longer residence time for complete combustion.

Crucial to minimizing $\mathrm{CO}$ in the combustion gases is maintaining an optimum excess air ratio, high enough to provide enough oxygen for complete combustion, but low enough to guarantee sufficient residence time for volatile matter to combust completely. This has been dealt with in Section 2.6.1 where the required height for complete combustion was designed. In general, and certainly when waste mixes with high volatile matter content are incinerated, the injection of secondary combustion air in the freeboard is recommended to assure complete combustion of volatiles entrained with the primary air $[56,69,117-118]$.

\subsubsection{Hydrochloric acid $(\mathrm{HCl})$}

Wastes incinerated in FBCs contain varying amounts of chlorine in the form of chlorinated organic compounds or chlorides. In municipal waste, typically about $50 \%$ of the chlorine comes from PVC [58]. During combustion, almost all the chlorine in the incinerated waste is volatilized and emitted mostly as gaseous $\mathrm{HCl}$ with limited amounts of volatile metal chlorides [58, 119]. Chyang et al. [59] co-incinerated coal and RDF in a vortexing FBC. The coal was assumed to contain only small traces of chlorine, but the MSW-derived RDF contained $0.85 \mathrm{wt} \%$ chlorine due to the presence of $\mathrm{PVC}$ and $\mathrm{NaCl}$. The authors demonstrated that the $\mathrm{HCl}$ concentration in the raw flue gas increased linearly from approximately 650 to $1000 \mathrm{ppm}$ when the RDF/coal ratio was increased from 0.5 to 1.0 . The $\mathrm{HCl}$ volatilized from the waste can partly convert to $\mathrm{Cl}_{2}$ following the Deacon reaction:

$4 \mathrm{HCl}+\mathrm{O}_{2} \leftrightarrow 2 \mathrm{Cl}_{2}+2 \mathrm{H}_{2} \mathrm{O}(6)$ 
Liu et al [119] demonstrated using a lab scale FBC, fed with simulated raw flue gas, that the formation of $\mathrm{Cl}_{2}$ was favored at temperatures above $600{ }^{\circ} \mathrm{C}$, in oxygen rich atmospheres and with relatively high $\mathrm{HCl}$ concentrations. Furthermore, the addition of ash in the $\mathrm{FBC}$ increased the $\mathrm{HCl}$ to $\mathrm{Cl}_{2}$ conversion rate, which might be due to the presence of $\mathrm{CuCl}_{2}, \mathrm{Cu}_{2} \mathrm{Cl}_{2}$ or other transition metal salts that are known catalysts of the Deacon reaction. The conversion rates $\left(\mathrm{HCl}\right.$ to $\left.\mathrm{Cl}_{2}\right)$ were in the order of a few percent.

Both $\mathrm{HCl}$ and $\mathrm{Cl}_{2}$ can cause corrosion problems in the combustor and in the post combustion zone, typically in the boiler tubes $[46,76]$. Furthermore, $\mathrm{Cl}_{2}$ appears the major chlorinating agent in the formation of toxic PCDD/Fs [119-120], so measures for $\mathrm{HCl}$ and $\mathrm{Cl}_{2}$ abatement in the flue gas are general practice in waste incinerating FBCs. The addition of calcium based compounds such as $\mathrm{CaCO}_{3}$ (limestone), $\mathrm{CaO}$, $\mathrm{Ca}(\mathrm{OH})_{2}$ or $\mathrm{CaSO}_{4}$ is a commonly applied technique for this purpose $[59,76,118$ 119]. Limestone is mostly introduced into the fluidized bed itself, and within the temperature range typical for waste incineration $\left(750-900^{\circ} \mathrm{C}\right)$, the limestone is rapidly calcined to the porous calcium oxide, that can subsequently capture hydrogen chloride to form $\mathrm{CaCl}_{2}$ [76]. Chyang et al. [59] incinerated RDF mixed with different amounts of $\mathrm{CaCO}_{3}$ and demonstrated that the $\mathrm{HCl}$ concentration in the combustor gas decreased sharply with an increase in molar ratios of $\mathrm{Ca} / \mathrm{Cl}$ from 0 to 5 , but a further increase of the $\mathrm{Ca} / \mathrm{Cl}$ ratio had little further decreasing effect. Typical temperatures in $\mathrm{FBCs}\left(700-850^{\circ} \mathrm{C}\right)$ do not favor the exothermic reaction of $\mathrm{HCl}$ and $\mathrm{CaO}$, and a higher $\mathrm{HCl}$ retention efficiency is measured in the temperature range of 550-650 ${ }^{\circ} \mathrm{C}$. This was also demonstrated by Chyang et al. [59], who observed that the chlorine content in the fly ash further increased at $\mathrm{Ca} / \mathrm{Cl}$ ratios in the RDFlimestone mixtures of 5 to 15 and explained this effect by a continuation of $\mathrm{HCl}$ 
binding when sorbent particles in the combustor are entrained into the lowtemperature zone behind the combustor such as heat exchanger, cyclone and other flue gas paths. In most commercial FBCs for waste incineration, in-bed removal of acid gases is commonly combined with a post-combustor injection of $\mathrm{CaO}, \mathrm{NaHCO}_{3}$ or milk of lime $\left(\mathrm{Ca}(\mathrm{OH})_{2}\right)$ as part of the dry or semi-dry flue gas treatment in order to reduce acid gas concentrations in the stack to far below emission standards. The reaction products generated are solid and need to be separated from the flue-gas as dust in a subsequent de-dusting stage, normally using a baghouse filter. In some installations, further removal of $\mathrm{HCl}$ takes place in a dedicated scrubber, using water at a $\mathrm{pH}$ close to neutral or alkaline by addition of $\mathrm{NaOH}$ [58].

\subsubsection{Sulphur oxides $\left(\mathrm{SO}_{\mathrm{x}}\right)$}

During incineration the sulfur containing compounds in the waste are oxidized and the acid gas $\mathrm{SO}_{2}$ is formed [58]. Xie et al. [76] and Liu et al. [119] suggest that $\mathrm{SO}_{2}$ can be oxidized to $\mathrm{SO}_{3}$ by $\mathrm{Cl}_{2}$ according to the reaction:

$\mathrm{Cl}_{2}+\mathrm{SO}_{2}+\mathrm{H}_{2} \mathrm{O} \leftrightarrow 2 \mathrm{HCl}+\mathrm{SO}_{3}(7)$

The BREF on waste incineration [58] states that the proportion of $\mathrm{SO}_{3}$ can be around $5 \%$ at the inlet to the flue gas cleaning stage when MSW is incinerated.

Both $\mathrm{SO}_{x}$ and $\mathrm{HCl}$ are acid flue gas compounds and need to be removed; similar abatement techniques can be used. When wastes with relatively high calcium contents such as MSW, sludge, some biomass species, and MBM are co-incinerated with e.g. coal, the $\mathrm{Ca}^{2+}$ present as $\mathrm{CaO}$ in the fly ash can also act as $\mathrm{SO}_{x} / \mathrm{HCl}$ absorption agent [60]. This explains why the co-incineration of calcium rich wastes in FBCs of high sulfur coal for energy production, reduces $\mathrm{SO}_{x}$ emissions to a larger extent than expected from the reduction of the sulfur content of the waste-coal mix 
alone $[55,60,73]$. Figure 12 illustrates the $\mathrm{SO}_{2}$ capturing efficiencies for the $\mathrm{CFBC}$ of Figure 5 using $\mathrm{CaO}$ as in-bed reactant. Efficiencies well in excess of $95 \%$ are common at $\mathrm{Ca}^{2+-}$-contents in the bed of 1 to $2 \mathrm{wt} \%$.

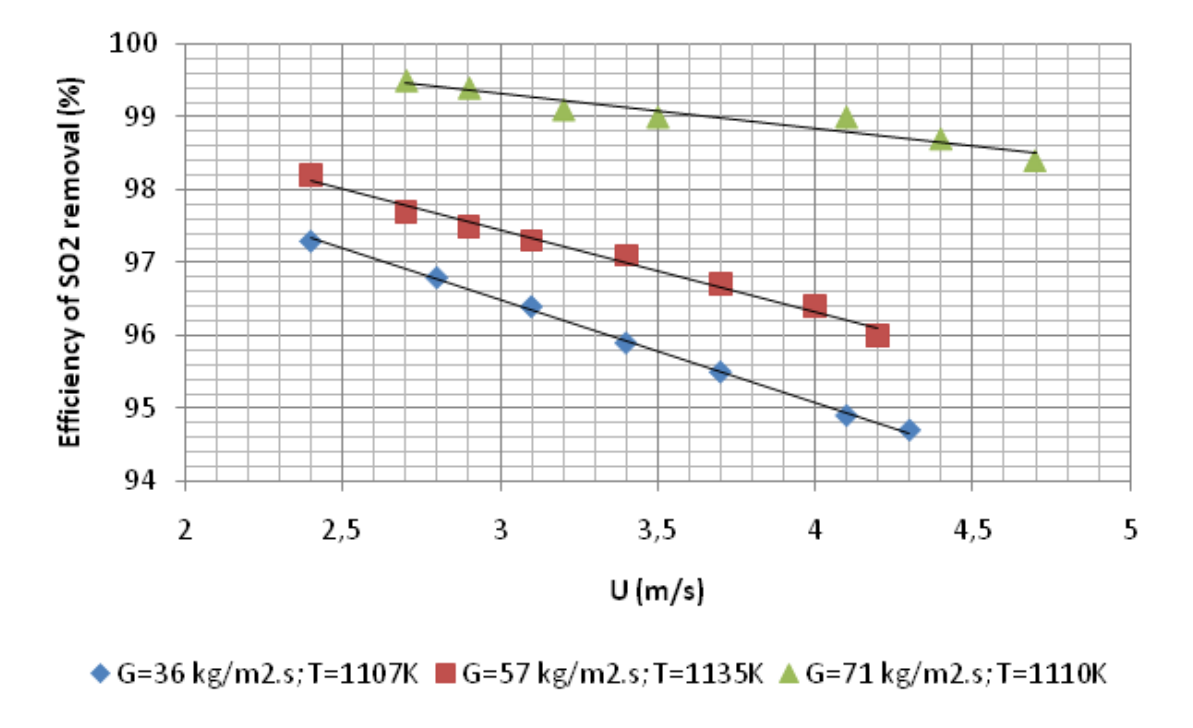

Figure 12. Efficiency of $\mathrm{SO} 2$ removal by $\mathrm{CaO}$ at $\mathrm{Ca} / \mathrm{S} \sim 2.7$ versus operating velocity at different solid circulation fluxes and temperatures in a $58 \mathrm{MWth}$ CFBC

In order to investigate the effect of $\mathrm{HCl}$ on $\mathrm{SO}_{x}$ absorption, Xie et al. [76] cocombusted PVC and coal in a bench scale FBC. They concluded that the $\mathrm{SO}_{x}$ capturing efficiency of $\mathrm{CaO}$ (injected as such or from calcined $\mathrm{CaCO}_{3}$ ) increased with increasing chlorine content of the fuel mix. $\mathrm{SO}_{\mathrm{x}}$ are trapped by reaction with $\mathrm{CaO}$ to form $\mathrm{CaSO}_{4}$ at the surface of the injected particles. Since the molar volume of $\mathrm{CaSO}_{4}$ exceeds that of $\mathrm{CaO}, \mathrm{CaSO}_{4}$ shields the $\mathrm{CaO}$ at the interior of the particle. Xie et al. [76] suggest that $\mathrm{CaCl}_{2}$ formed by the reaction of $\mathrm{CaO}$ with $\mathrm{HCl}$, and with lower molar volume, keeps the reacted sulfate-shell porous, thus providing diffusion paths for $\mathrm{SO}_{\mathrm{x}}$ toward the interior of the particle, leading to increased $\mathrm{SO}_{x}$ capture. Hernandez Anatol et al. [56] confirmed that the $\mathrm{SO}_{x}$ capturing efficiency of calcium compounds is sensitive to the chloride content of the combusted waste. 
One of the drawbacks of increasing the $\mathrm{SO}_{x}$ capture in the combustion gases is an increase in the concentration of soluble sulfates in the fly ashes or flue gas cleaning residue. In this way, the sulfate concentration in the leachate from these solid residues may exceed the limits for the acceptance as inert or even non-hazardous waste set by the EU Directive 2003/33/EC while also impeding further recycling options [55].

\subsubsection{Nitrogen containing emissions : $\mathrm{NO}_{x}$ and $\mathrm{N}_{2} \mathrm{O}$}

Nitrogen oxides $\left(\mathrm{NO}_{\mathrm{x}}\right)$ are generally emitted as nitric oxide $(\mathrm{NO})$, accounting for up to $95 \%$ of $\mathrm{NO}_{\mathrm{x}}$ emissions [23], and contribute to acidification, photochemical ozone creation and eutrophication. Nitrous oxide emissions $\left(\mathrm{N}_{2} \mathrm{O}\right)$ are negligible for most combustion processes, but can become significant in fluidized bed combustion, because of its specific temperature range; $\mathrm{N}_{2} \mathrm{O}$ is considered a greenhouse gas.

Because of the low operating temperatures of a FBC, oxidation of the organically bound nitrogen in the fuel (fuel- $\mathrm{N}$ ) is found to be the main source of $\mathrm{NO}_{x}$ and $\mathrm{N}_{2} \mathrm{O}$. Figure 13 illustrates the most important pathways of the conversion of fuel-N in an FBC [121].

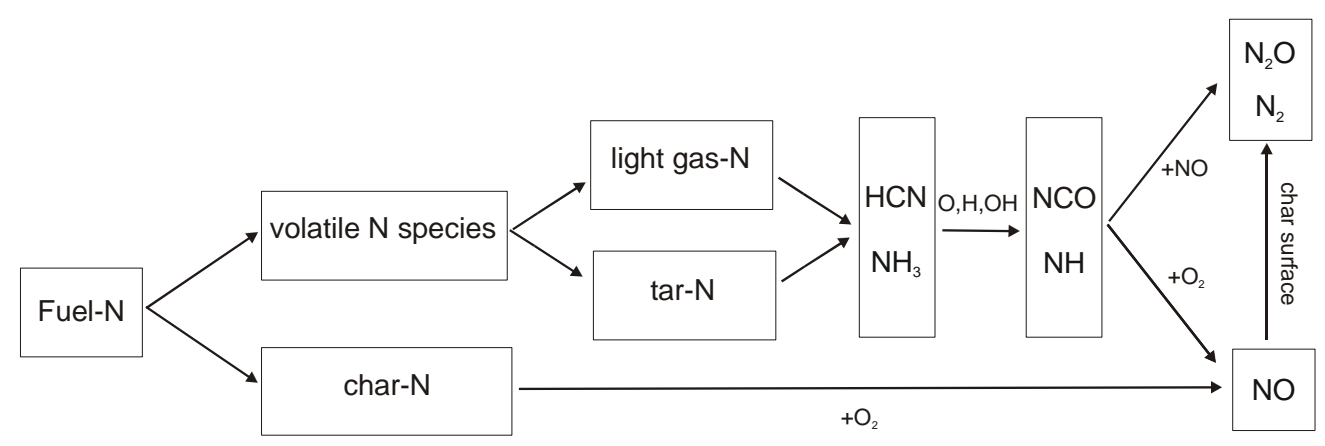

Figure 13. Most important fuel-N conversion pathways 
The distribution of the fuel- $\mathrm{N}$ between volatiles and char, as well as the distribution of the volatile $\mathrm{N}$ species depends mainly on the operating conditions (e.g. temperature, excess air) of the incinerator and on the properties of the solid fuel [122-123]. During fluidized bed combustion most of the fuel-N (66-80\%) is released during devolatilization as volatile-N species $[57,124]$. Depending on the functionality of the nitrogen in the input, one of the primary intermediates $\mathrm{NH}_{3}$ or $\mathrm{HCN}$ will preferentially be formed. High rank solid fuels (with a high carbon content) mainly contain nitrogen bound in heterocyclic ring structures, and will mainly form $\mathrm{NH}_{3}$ as primary intermediate, while low rank fuels mainly contain nitrogen in the form of amines and quaternary- $\mathrm{N}$ and will rather form $\mathrm{HCN}$ [121]. The main oxidation routes of $\mathrm{NH}_{3}$ lead to $\mathrm{NO}$ and $\mathrm{N}_{2}$, whereas $\mathrm{HCN}$ is generally seen as the most important precursor to $\mathrm{N}_{2} \mathrm{O}$, especially in the temperature range of a FBC. This way, the combustion of biomass in a FBC will lead to substantially less formation of $\mathrm{N}_{2} \mathrm{O}$, in contrast to the combustion of coal, which is a higher rank solid fuel. The accurate prediction of NO and $\mathrm{N}_{2} \mathrm{O}$ emissions from different solid fuels during fluidized bed combustion has been found difficult, due to the complexity of their formation process, described by hundreds of elementary reactions [122, 125-126]. Various literature sources have proposed a linear relationship between the conversion of fuel- $\mathrm{N}$ to $\mathrm{NO}$ and the $\mathrm{O} / \mathrm{N}$, $\mathrm{H} / \mathrm{N}$ or $\mathrm{CH} / \mathrm{N}$ weight ratios of the solid fuel [121, 127-129]. General agreement thus exists on the inverse linear correlation of fuel-N and its conversion to $\mathrm{NO}$, because high concentrations of fuel- $\mathrm{N}$ (hence low $\mathrm{O} / \mathrm{N}, \mathrm{H} / \mathrm{N}$ or $\mathrm{CH} / \mathrm{N}$ ratios) result in more nitrogen containing species (intermediates and oxides) that can react to form $\mathrm{N}_{2}$ and $\mathrm{N}_{2} \mathrm{O}$ as can be seen in Figure 13.

There are various ways to control and/or reduce $\mathrm{NO}_{x}$ emissions during fluidized bed combustion. The most important techniques are combustion modifications, such as 
air and/or fuel staging, and a DeNOx installation (SCR or SNCR) $[23,58,130]$. The basic idea of air staging is controlling $\mathrm{NO}_{\mathrm{x}}$ formation by controlling the oxygen availability, as $\mathrm{NO}_{x}$ emissions are positively correlated to the air excess. Air staging limits the oxygen availability in the high temperature zone, creating an oxygen lean primary combustion zone in which a considerable part of the fuel- $\mathrm{N}$ is released as $\mathrm{N}_{2}$ [131-132]. The oxygen excess in the secondary combustion zone is kept to a strict minimum, preferably as low as $3 \%$, reducing the total amount of NO finally formed. Problems can occur, however, when the oxygen level is so low that combustion is incomplete (Section 3.2.1). By applying air staging, the $\mathrm{NO}_{x}$ emissions can typically be reduced by $30-60 \%[23,130]$. Fuel staging of waste feed, where a proportion of fuel is injected above the combustion zone to create a fuel rich secondary combustion zone where the $\mathrm{NO}_{x}$ already formed in the primary combustion zone is reduced by about $50 \%$ through decomposition, is however difficult to achieve in FBCs.

Besides these preventive combustion modifications, many FBCs nowadays implement DeNOx techniques (SCR or SNCR), enabling further reduction of $50-80 \%$ of $\mathrm{NO}_{x}$ emissions by addition of $\mathrm{NH}_{3}$. Mahmoudi et al. [23] demonstrated that a maximal reduction of $\mathrm{NO}_{\mathrm{x}}$ emissions of about $84 \%$ could be achieved by SNCR for a $\mathrm{NH}_{3} / \mathrm{NO}$-ratio of $0.9-1.2$, independent of the original $\mathrm{NO}_{x}$ concentration, but influenced by the operating temperature, as illustrated in Figure 14 . 


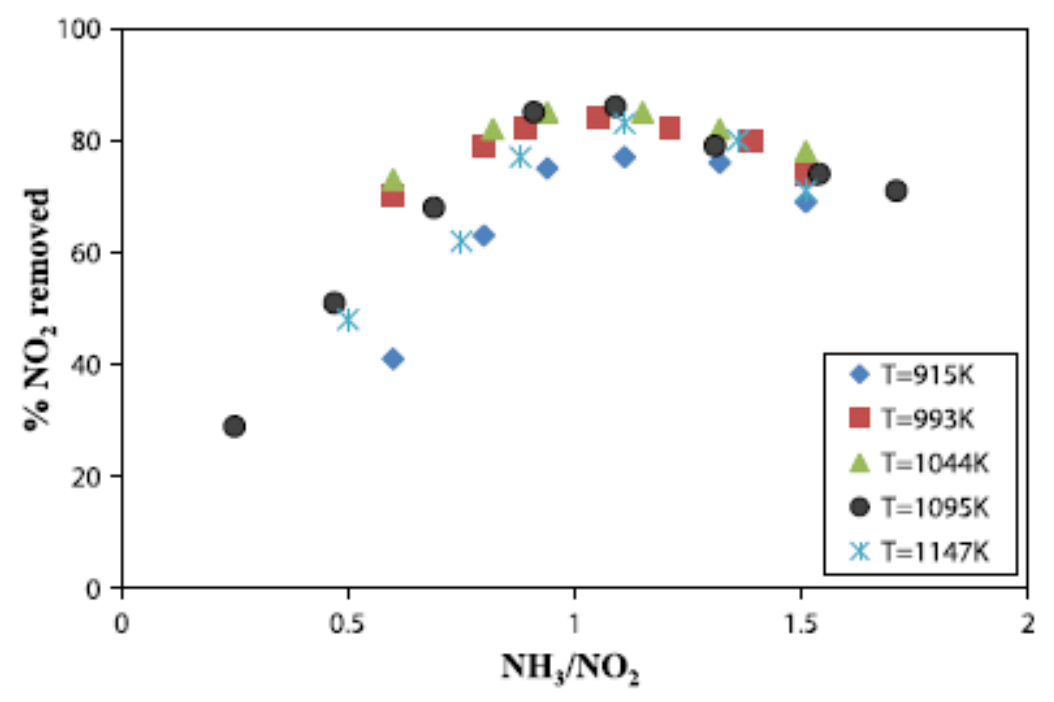

Figure 14. DeNOx-efficiencies in a CFBC at various NH3/NOx ratios and temperatures [24]

\subsubsection{Particulate matter (PM)}

Particulate matter (PM) or dust is generally classified according to the aerodynamic diameter of the dust particles. PM 10 for instance, refers to particulate matter with an aerodynamic diameter smaller than $10 \mu \mathrm{m}$. PM 10 is generally not retained in the nose and throat and can settle in the bronchi and lungs thus causing health problems such as asthma and lung cancer. Particles with an aerodynamic diameter smaller than $2.5 \mu \mathrm{m}, \mathrm{PM} 2.5$, tend to penetrate into the gas exchange regions of the lung, and ultrafine particles (aerodynamic diameter $<0.1 \mu \mathrm{m}$ ) may pass through the lungs leading to e.g. plaque deposits in arteries, causing atherosclerosis, which can lead to heart attacks and other cardiovascular problems [133].

Particulate emissions from a fluidized bed combustion system can be classified into two broad classes: particles from incomplete combustion (soot, condensed organic matter or tar) and carbonaceous residues or char on the one hand, and particles from the mineral compounds in the fuel on the other hand. In the latter class, the coarser 
particles $(1-10 \mu \mathrm{m})$ result from agglomeration of non-volatile elements in burning char particles; the finer particles $(<1 \mu \mathrm{m})$, are largely produced from nucleation and condensation of compounds based on volatile elements such as $\mathrm{K}, \mathrm{Na}$ and $\mathrm{Cl}$. [46, 71].

Compared to the formation of the pollutants described in Sections 3.2.1 to 3.2.4, the formation of particulate matter in FBCs incinerating waste received little attention so far. Lopes et al. [71] investigated the influence of the co-incineration of biomass with coal on the particle size distribution of PM emitted at the stack of a pilot scale FBC in which fly ash was retained in a two stage cyclonic separator. They concluded that, when the share of biofuels was increased and also during combustion of pure biofuels, especially olive bagasse, straw and MBM, the fraction of particles with an aerodynamic diameter of less than $1 \mu \mathrm{m}$ in the flue gas increased. They accord this to the production of higher amounts of $\mathrm{KCl}$ and/or $\mathrm{NaCl}$ aerosols, since the biofuels contain a higher total amount of $\mathrm{K}, \mathrm{Na}$ and $\mathrm{Cl}$. Furthermore, the addition of the biofuels, which have a high volatile matter content, enhanced the combustion efficiency of coal thus decreasing the amount of coarser PM.

When waste is incinerated in FBCs with energy recovery, the coarser part of the PM present in the raw flue gas is removed in the steam boiler and collected as boiler ash. In most installations, an electrostatic precipitator or a baghouse filter is used to further remove PM from the flue gas before it is treated to remove acid gases (Section 3.2.2). This has the advantage that the fly ash is separated from the other flue gas cleaning residues which allows its separate treatment. Depending on the design and size of the de-dusting unit, the PM concentration in the flue gas can normally be reduced to $15-25 \mathrm{mg} / \mathrm{m}^{3}$. PM not retained at this stage, can be removed with the residue of the semi-dry flue gas treatment. As shown in Table 9, PM 10 
concentrations in the flue gas emitted at the stack of FBCs incinerating waste are generally very low.

\subsection{Pollutants present in both flue gas and ashes}

\subsubsection{Polychlorinated dioxins and furans (PCDD/Fs)}

PCDD/Fs constitute a group of 75 PCDD- and 135 PCDF-congeners with chlorine atoms at different positions of the two aromatic rings of the molecules. Because of their resistance to chemical degradation, these toxic pollutants can remain intact for many years and become widely distributed throughout the environment. They accumulate in the fatty tissue of animals and humans and their toxic effects include cancer, allergies and developmental effects.

It was found that in full scale FBCs the incoming PCDD/Fs from the waste are effectively destroyed during incineration, regardless of their concentration [134-135]. FBCs can effectively destroy PCDD/Fs and other hazardous substances at relatively low temperatures (typical hazardous waste incinerators such as rotary kilns generally maintain temperatures of $1000^{\circ} \mathrm{C}$ or higher, approximately $150^{\circ} \mathrm{C}$ higher than in FBCs) because the incineration process is a "continuum of flaming combustion" offering highly isothermal conditions, longer residence times, and better mixing than many conventional combustion systems such as grate or rotary furnaces [136].

PCDD/Fs found in the flue gas, the fly and boiler ash and the FGCR do not originate directly from the waste, but are the result of de novo synthesis: a re-combination reaction of carbon (bound in an aromatic matrix), oxygen and chlorine on ash particles in the post combustion stage, at temperatures of $250-450{ }^{\circ} \mathrm{C}$. The formation of PCDD/Fs from suitable products of incomplete combustion called precursors such as chlorinated benzenes (PCBz) and phenols (PCPh), which has 
been shown to be an important formation pathway in many lab-scale experiments [120], appears of no significance in actual, full scale FBCs [134-135].

The parameters influencing PCDD/F reformation in FBCS were investigated by different research groups [66-67, 136-137]. Huotari and Vesterinen [67] demonstrated that in a lab scale FBC co-incinerating RDF with peat, wood bark and coal the following variables positively correlated with the PCDD/F concentration in the flue gas: $\mathrm{CO}$ and $\mathrm{PAH}$ concentration in the flue gas, the number of $\mathrm{CO}$ concentration peaks in the flue gas during the measuring period, the chlorine concentration in the fuel and the $\mathrm{Cl} / \mathrm{S}$ of the fuel, the concentration of PCBz, PCPh and PCBs in the flue gas and the copper concentration in the fly ash. The combustion temperature was negatively correlated with the PCDD/F concentration in flue gas. The PCDD/F concentration $(\mathrm{pg} / \mathrm{g})$ in the fly ash separated by the ESP was also studied and it was found that the PCDD/F concentration increased with increasing concentration of combustibles, chlorine and 1,2,4-chlorobenzene in the fly ash.

The role of the $\mathrm{Cl} / \mathrm{S}$ ratio of the fuel in the formation of PCDD/Fs in FBCs was investigated in more detail by Anthony et al. [136], Preto et al. [137] and Gulyurtlu et al. [66]. In general, when the $\mathrm{Cl} / \mathrm{S}$ ratio of the fuel decreases, lower amounts of PCDD/Fs are formed. The possible interactions of chlorine and sulfur in the formation of PCDD/Fs were already theoretically suggested in the 1980s [136]. First of all, $\mathrm{SO}_{2}$ can react with $\mathrm{Cl}_{2}$ to form $\mathrm{HCl}$ (reaction 7 in Section 3.2.3), which has been proven to be a poor chlorinating agent for aromatics compared to $\mathrm{Cl}_{2}$ [120]. Furthermore, $\mathrm{SO}_{x}$ can reduce the activity of $\mathrm{CuCl}_{2}, \mathrm{Cu}_{2} \mathrm{Cl}_{2}$ or other copper salts that catalyze the Deacon reaction, in which $\mathrm{Cl}_{2}$ is formed from $\mathrm{HCl}$ (reaction 6 in Section 3.2.2), and catalyze the formation of PCDD/F in fly ash. Anthony et al. [136] demonstrated by means of lab scale experiments that when the $\mathrm{CI} / \mathrm{S}$ ratio of the combusted fuel was 
decreased from 12.5 to 1 , the PCDD/F concentration in the flue gas decreased by approximately $20 \%$. When however the $\mathrm{Cl} / \mathrm{S}$ ratio was further decreased to 0.5 , the PCDD/F concentration in the flue gas increased again. Anthony et al [136] explain this increase by the fact that $\mathrm{SO}_{2}$ can suppress radical populations towards equilibrium levels, where in general in FBCs the oxidation of $\mathrm{CO}$ and volatiles is controlled by super-equilibrium concentrations of free radicals. The suppression of free radicals enhances the production of unburned hydrocarbons, which can serve as reaction surface in the novo synthesis of PCDD/Fs. Lopes et al. [71] showed that $\mathrm{PCDD} / \mathrm{F}$ emissions increased as the share of MBM or straw in the waste-coal feed mix increased. In accordance with Anthony et al. [136], the authors attribute the increase to the lower $\mathrm{SO}_{x}$ concentrations in the flue gas when the share of coal, containing more sulfur and less calcium than the two biowastes, decreased. They also found that relatively more fine particulate matter $(<1 \mu \mathrm{m})$ was present in the fly ash of waste mixes with higher shares of MBM and straw. As smaller particles have a larger specific surface, relatively more area was available for PCDD/F formation. In addition, the presence of chlorine from the biowastes enhanced copper volatility resulting in higher concentrations of copper in the smaller size particles, which may also have contributed to higher PCDD/F emissions with the increasing biowaste addition. Van Canegem et al. [135] also reported that copper and PCDD/F concentrations in FBC-fly ash are positively correlated.

Achieving the emission level of $0.1 \mathrm{ngTEQ} / \mathrm{Nm}^{3}$ set by the European Waste Directive (2000/76/EC), generally involves a combination of preventive, combustion related techniques to reduce PCDD/F formation, and end-of-pipe measures to reduce the concentration in the flue gas before emission at the stack. The main prevention of $\mathrm{PCDD} / \mathrm{F}$-formation in FBCs is a well controlled combustion process, preventing the 
presence of products of incomplete combustion that may act as reaction surface and/ or as precursors. Optimization of both the design of the FBC (Section 2) and of the operating parameters such as residence time, air distribution, combustion temperature, waste throughput etc are crucial to achieve complete burnout and hence limit the formation of PCDD/Fs. Also the limitation of the flue gas residence time in the 200 to $400^{\circ} \mathrm{C}$ temperature zone, typically achieved in the boiler and during the first steps of flue gas cleaning can help to reduce PCDD/F formation. Especially in dust removal devices (commonly electrostatic precipitators or bag filters) gas temperatures should be kept below $200^{\circ} \mathrm{C}$. The most commonly used end-of-pipe technique to remove PCDD/Fs from dedusted flue gas is adsorption on activated carbon or lignite powder particles, often injected along with lime or sodium bicarbonate used for acid gas removal [58]. The injected reagents and their reaction products are then collected in a secondary deduster, usually a baghouse filter. SCR systems, primarily used for $\mathrm{NO}_{x}$ reduction can, if large enough, also sufficiently destroy PCDD/Fs in dedusted flue gas through catalytic oxidation, since the catalysts used for both reactions are the same [138-139]. The emission standard of $0.1 \mathrm{ng}$ $\mathrm{TEQ} / \mathrm{Nm}^{3}$ is then easily met. The advantage of SCR, if placed upstream of further flue gas treatment, is that the flue gas cleaning residue is less contaminated with PCDD/Fs.

\subsubsection{Polyaromatic hydrocarbons (PAHs)}

Polyaromatic hydrocarbons consist of at least 2 fused aromatic rings and contain only carbon and hydrogen atoms. Their toxicity is related to their structure; several PAHs such as benz[a]anthracene, benzo[a]pyrene and chrysene have been shown carcinogenic, mutagenic and/or teratogenic. 
PAHs are considered as products of incomplete combustion [140]. The PAHs found in the flue gas and in the fly ash of FBCs incinerating waste can either be directly volatilized from the waste or can be the result of recombination of free radicals resulting from cracking of volatilized organic compounds during the pyrolysis step of combustion, called pyrosynthesis. When the volatilized or recombined PAHs are entrained with the combustion air without further destruction (by oxidation), they are found in the flue gas, fly ash and FGCR [140-143]. Atal et al. [143] incinerated a mixture of pulverized coal and waste automobile tire crumb spiked with deuterium labelled PAH standards of fluorene, phenanthrene and pyrene in a lab scale combustor at a temperature of $1150^{\circ} \mathrm{C}$, which is higher than in most $\mathrm{FBC}$ systems. They demonstrated that the PAHs in the flue gas and in the ash should be attributed to pyrosynthesis as the PAHs detected in these outputs contained none of the deuterated species added to the coal-waste mix. The fact that PAHs in the waste are destroyed and that the PAHs found in the flue gas and fly ash are newly formed was also confirmed by the results of Van Caneghem et al. (unpublished results). They measured the concentration of the 16 EPA-PAHs in ASR, RDF from MSW and wastewater treatment sludge fed into a commercial FBC and compared the PAH concentration profiles or "fingerprints" to those of the flue gas and fly ash. The PAH fingerprints of ASR and RDF were dominated by PAHs with at least 3 rings, fluoranthene, fenanthrene and chrysene being the most important. In the flue gas however, $99 \%$ of the total PAH concentration was accounted for by naphthalene (two ring $\mathrm{PAH})$, which was not detectable $(<1 \mathrm{mg} / \mathrm{kg})$ in ASR and contributed for only $6 \%$ to the total PAH concentration in RDF.

The influence of the combustion temperature on PAH formation is twofold. At lower temperatures, the formation rate of PAHs during the pyrolysis step is lower, resulting 
in lower PAH concentrations in the raw flue gas. At higher temperatures, however, also the rate of destruction by oxidation of newly formed PAHs increases and when it exceeds the rate of formation, the PAH concentration in the raw flue gas drops.

Gulyurtlu et al. [140] incinerated coconut shells in a pilot scale FBC at temperatures between 675 and $850^{\circ} \mathrm{C}$ and found that at $750^{\circ} \mathrm{C}$ the $\mathrm{PAH}$ concentration in the raw flue gas was highest. The authors also showed that the moisture content and particle size ( 1 to $3.2 \mathrm{~mm}$ ) of the coconut shells did not have a significant influence on the $\mathrm{PAH}$ concentration in the flue gas.

As mentioned in Section 3.3.1, sulfur can suppress the formation of free radicals during the pyrolysis step of combustion, leading to an increased amount of products of incomplete combustion, such as PAHs. This was confirmed by measurements of the PAH concentration in the raw flue gas of a lab-scale FBC [136]: when the $\mathrm{Cl} / \mathrm{S}$ ratio of the waste mix decreased from 12 to 1 , the PAH concentration in the flue gas almost doubled.

Considering PAHs in incineration ashes, it appears that ash particles with intermediate diameters $(75-100 \mu \mathrm{m})$ show the lowest PAH concentrations [141]. Smaller particles $(45-75 \mu \mathrm{m}$ and 0.5-45 $\mu \mathrm{m})$ have higher PAH concentrations, which can be explained by the higher specific surface area increasing PAH adsorption per mass unit. In the particular case of rice husk incineration in a conical pilot scale FBC, the coarsest fly ash particles $(>200 \mu \mathrm{m})$ showed the highest PAH concentration, which could be explained by their particular surface texture with hygroscopic pore structures increasing the surface available for PAH adsorption. This theory was supported by SEM images of the coarse, fine and intermediate fly ash particles [141]. 
In order to limit the PAH concentration in the flue gas, it is important to maintain an adequate excess air ratio to favor mixing of waste and combustion air, hence minimizing the formation of 'fuel rich pockets', which favor PAH formation and maximizing complete oxidation of PAHs formed [140].

Techniques used to control the $\mathrm{PAH}$ emissions of FBCs incinerating waste are the same as for the control of PCDD/F i.e. good control of the combustion process ensuring complete burnout and injection of adsorption agents such as activated carbon in the flue gases [58].

\subsubsection{Heavy metals}

Heavy metals represent a loosely-defined group of metal elements including As, Cd, $\mathrm{Co}, \mathrm{Cr}, \mathrm{Cu}, \mathrm{Hg}, \mathrm{Mn}, \mathrm{Ni}, \mathrm{Pb}, \mathrm{V}$ and $\mathrm{Zn}$. Some of these metals, such as $\mathrm{Co}, \mathrm{Cu}, \mathrm{Mn}$ and $\mathrm{Zn}$, are trace elements meaning they are essential to the normal metabolism of humans but can be toxic at high levels of exposure. Other heavy metals such as $\mathrm{Hg}$ and $\mathrm{Pb}$ are xenobiotic: they have no known vital or beneficial effect and can exert toxic effects when they accumulate in e.g. bone or liver, kidney and brain tissue [144145].

Metals present in the waste incinerated in a FBC can either remain in the bottom ash, be retained in the fly ash or be vaporized and entrained with the raw flue gas. This so called partitioning not only depends on the physical en chemical properties of the metal, but is also related to the presence of gaseous pollutants such as $\mathrm{HCl}, \mathrm{SO}_{2}$, unburned carbon, and particulate matter in the flue gas, to the design of the installation e.g. the location and amount of secondary air injection and to the temperatures during flue gas treatment [70]. Figure 15 gives the vapor pressure of relevant heavy metals and their salts as an indication of their volatility [40]. 


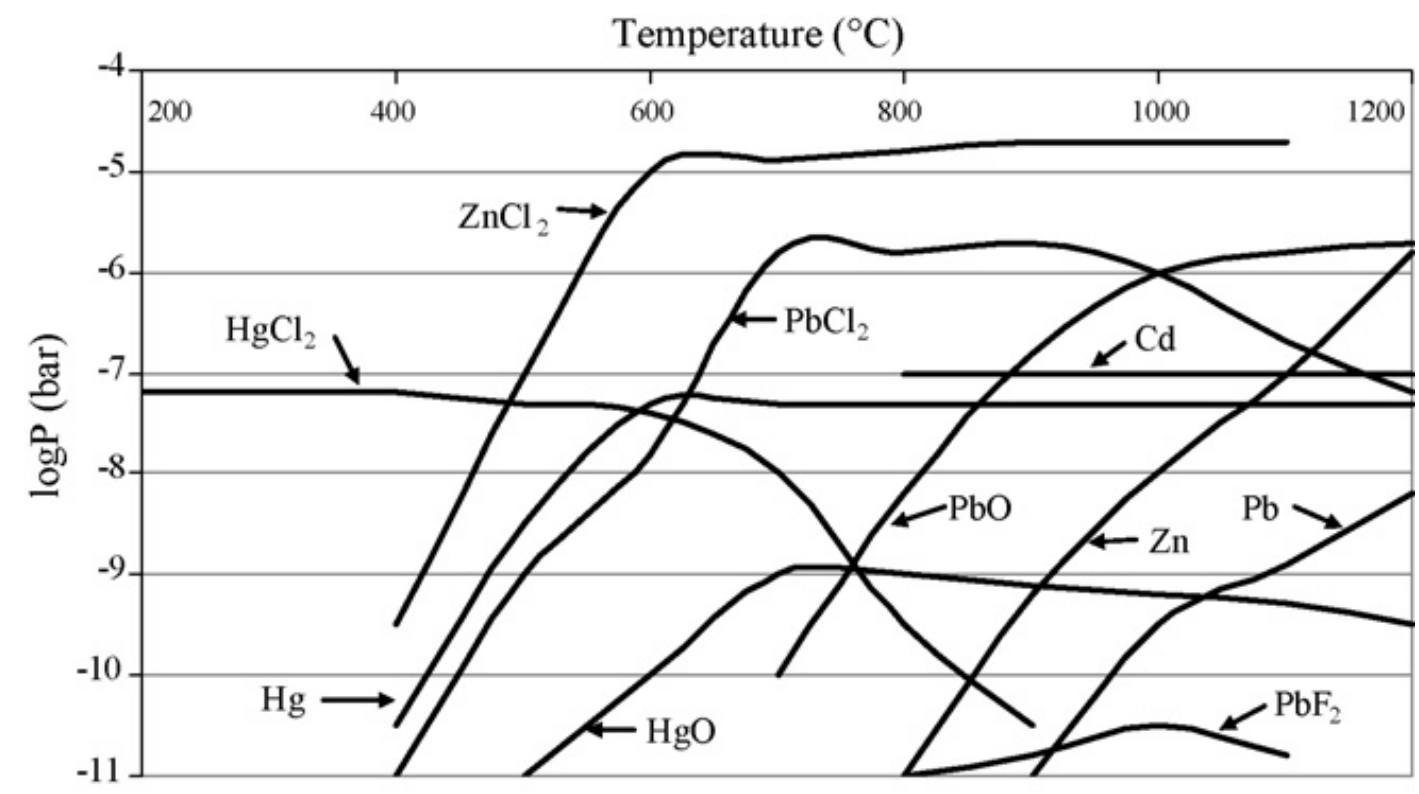

Figure 15. Vapor pressure of relevant heavy metals and their salts [28].

\subsubsection{Mercury $(\mathrm{Hg})$}

$\mathrm{Hg}$ is the most volatile heavy metal; it has a boiling point of $357^{\circ} \mathrm{C}$. It is vaporized as elemental $\mathrm{Hg}$ inside the furnaces, and, as the flue gas cools, while passing through the subsequent heat exchangers and flue gas treatment, oxidation may take place, generating $\mathrm{Hg}^{+}$or $\mathrm{Hg}^{2+}$-oxides and -salts, e.g. $\mathrm{HgO}_{1} \mathrm{HgCl}_{2}$ or $\mathrm{Hg}_{2} \mathrm{Cl}_{2}$ and $\mathrm{HgSO}_{4}$ depending on the availability of $\mathrm{Hg}$, oxidants and on temperature. The formed $\mathrm{Hg}$ oxides and -salts can be adsorbed on the entrained fly ashes [70]. $\mathrm{Hg}$ present in the waste as oxide or chloride may be directly vaporized as such.

When biomass is co-incinerated with coal, the $\mathrm{Hg}$ retention in the generated fly ashes increases compared to pure coal combustion [70, 146]. Lopes et al. [70] studied the partitioning of $\mathrm{Hg}$ during the co-combustion of sewage sludge with coal in a $90 \mathrm{~kW}$ pilot scale FBC. The total amount of $\mathrm{Hg}$ (reported as the sum of $\mathrm{Hg}$ bound to particulate matter and $\mathrm{Hg}$ in the vapor phase) in the flue gas, after collection of fly ash in a series of two cyclones, increased when sewage sludge was co-incinerated, 
but less than could be expected from the increase of the $\mathrm{Hg}$ concentration in the sludge-coal mix compared to coal. Lopes et al. [70] generally concluded that retention of $\mathrm{Hg}$ in the cyclone ashes was very important, probably because of the high quantities of unburned carbon, having a positive catalytic effect on the oxidation of $\mathrm{Hg}$.

Results from different lab scale experiments $[63,70,146]$ suggest that at sufficient residence times and at temperatures below $300^{\circ} \mathrm{C}$, as in e.g. the ash collection devices, $\mathrm{SO}_{2}$ adsorbed on the ash particles can generate $\mathrm{SO}_{3}$ and $\mathrm{H}_{2} \mathrm{SO}_{4}$, leading to formation of $\mathrm{HgSO}_{4}$, which is chemically adsorbed.

Van de Velden et al. [40] investigated the partitioning of heavy metals in a real scale FBC for sludge incineration and concluded that $\mathrm{Hg}$ was not retained efficiently in the fly ash and was significantly present in the flue gas emitted at the stack, despite the presence of scrubbers. The stack gas emissions complied however with local regulations. Since the mass balance for $\mathrm{Hg}$ could not be closed (the outputs only contained $65 \%$ of the $\mathrm{Hg}$ in the input) due to the limited sampling of the flue gas, it was not possible to quantitatively discuss the partitioning.

Metallic $\mathrm{Hg}$ is virtually insoluble in water $\left(59 \mu \mathrm{g} / \mathrm{l}\right.$ at $\left.25^{\circ} \mathrm{C}\right) . \mathrm{HgCl}_{2}$ is much more soluble $(73 \mathrm{~g} / \mathrm{l})$ and can therefore be separated in wet scrubbers, but the removal efficiency can be reduced if $\mathrm{SO}_{2}$ is also present. Efficient removal of $\mathrm{HgCl}_{2}$ therefore requires prior and distinct $\mathrm{SO}_{2}$ removal by limestone injection. The removal of metallic $\mathrm{Hg}$ is obtained by direct deposition on sulfur doped activated carbon, hearth furnace coke, or zeolites [58].

\subsubsection{Other heavy metals}


The partitioning of heavy metals in FBCs not only depends on the properties of the metal in question, but also on its speciation, which depends on the chlorine and sulfur concentration in the fluidized bed.

Different lab scale experiments show that Co and Cu mostly remain in the bottom ash, while $\mathrm{Cd}, \mathrm{Pb}$ and $\mathrm{Zn}$ are mostly found in the fly ash; $\mathrm{Cr}, \mathrm{Mn}, \mathrm{Ni}$ and $\mathrm{V}$ are more or less equally distributed between bottom and fly ash [70, 146-147]. Miller et al. [146] paid, next to the partitioning of $\mathrm{Hg}$ and $\mathrm{Cd}$, special attention to the partitioning of $\mathrm{Mn}$ by co-combusting agricultural waste, pulp sludge or plastic waste with spruce wood-bark under simulated fluidized bed conditions. The ratio between the Mn mass retained in the total ash (fly ash and bottom ash) residue and the mass in the fuel fed into the reactor was calculated. The Mn retention in ashes of pure wood-bark combustion was good, (75-90\%) but addition of agricultural waste, pulp sludge or plastic waste reduced retention in the ashes markedly (in some cases to as little as $30 \%)$. The authors do however not suggest reasons for this observation and only state serious attention must be given to the behavior of $\mathrm{Mn}$ when co-combusting fuels with different compositions. The same study showed that besides $\mathrm{Hg}$ (Section 3.3.3.1), Cd was the only heavy metal for which the retention ratio decreased (more Cd was entrained with the flue gas) when any of the three wastes were cocombusted with wood-bark. The bad retention of $\mathrm{Cd}$ is not surprisingly as thermodynamic equilibrium modeling predicts that the metal completely vaporizes above $730^{\circ} \mathrm{C}$ (as one or more of the species $\mathrm{CdOH}$, elemental $\mathrm{Cd}$ or $\mathrm{CdCl}_{2}$ ) and the experiments were carried out at 800 and $900^{\circ} \mathrm{C}$. The lab scale observations of Lopes et al. [70], Miller et al. [146] and Shao et al. [147] do not fully corroborate the findings of Van de Velden et al. [40], who showed that in a real scale FBC 
incinerating sewage sludge, not only $\mathrm{Cr}, \mathrm{Cu}$ and $\mathrm{Ni}$ but also $\mathrm{Cd}, \mathrm{Pb}$ and $\mathrm{Zn}$ were efficiently retained in the fly ash.

\subsubsection{Leaching of heavy metals from FBC ashes}

In the EU, the classification of FBC ashes and residues as inert, non-hazardous or hazardous waste partly depends on the leaching of heavy metals and is regulated by council decision 2003/33/EC. The recycling of waste incinerator ashes as e.g. construction material or fertilizer is not yet regulated on the European level, but in many countries limit values for the leaching of heavy metals from waste to be recycled exist [148]. The leaching behavior of heavy metals in fly ash is strongly influenced by their concentration, speciation and mode of occurrence $[55,68,149]$, which on their turn depend on the composition of the incinerated waste.

Izquierdo et al. [68] studied the influence of the waste composition on leaching of heavy metals from FBC fly ash resulting from the incineration of wood pellets, sewage sludge and blends of these wastes with coal and coal tailings in real scale installations. There was no significant difference in the overall leaching of the fly ash samples of the different waste blends. $\mathrm{Cd}, \mathrm{Ni}, \mathrm{Pb}, \mathrm{Hg}, \mathrm{Cu}$ or $\mathrm{Zn}$ showed markedly low extractable levels and leaching was well below the acceptance landfill criteria of inert waste set by EU Directive 2003/33/EC. Se, Sb, Mo, Cr and As behaved however as oxyanions in the alkaline liquid/solid environment and showed considerable leaching. As a result, the acceptance landfill criteria of inert waste were not met for these elements. Only a few heavy metals (Mo, Sb and $\mathrm{V}$ ) revealed a correlation between their concentration in the fly ash and the leached concentration. Gulyurtlu et al. [55] conducted MBM and coal co-combustion experiments and also concluded that for 
most heavy metals there was no correlation between the concentration in the ashes and their leachability.

Abbas et al. [149] studied the behavior of $\mathrm{Cr}$ in different ashes from a real scale FBC incinerating a mixture of MSW and comparable industrial waste. Even though the total Cr concentration was similar in all ashes (bottom, hopper, cyclone and filter ash) studied, $\mathrm{Cr}(\mathrm{VI})$ levels in test leachates from the bottom ash were about thousand times higher than in test leachates from the other ashes. However, it was found that the leached amount of $\mathrm{Cr}(\mathrm{VI})$ from the bottom ash decreased significantly when this ash was mixed with the hopper ash. The authors suggest the coupled oxidation of $\mathrm{Al}(0)$ to $\mathrm{Al}(\mathrm{III})$ and reduction of $\mathrm{Cr}(\mathrm{VI})$ to $\mathrm{Cr}(\mathrm{III})$ as the most probable cause for the decrease. The finding that the mixing of two ash streams from the same boiler could result in the immobilization of Cr points at a simple stabilization method.

Table 10 summarizes, for the major gaseous pollutants, the concentrations formed in the combustor, the recommended abatement techniques and typical concentrations to be expected in the emitted flue gas of commercial FBC boilers incinerating MSW.

Table 10. Elemental ash composition (expressed as oxides) of different FBC feeds

\begin{tabular}{|l|l|l|l|l|l|l|l|l|l|l|}
\hline Sample & $\mathrm{SiO}$ & $\mathrm{CaO}$ & $\mathrm{K}_{2} \mathrm{O}$ & $\mathrm{P}_{2} \mathrm{O}_{5}$ & $\mathrm{Al}_{2} \mathrm{O}_{3}$ & $\mathrm{MgO}$ & $\mathrm{Fe}_{2} \mathrm{O}_{3}$ & $\mathrm{SO}_{3}$ & $\mathrm{Na}_{2} \mathrm{O}$ & $\mathrm{TiO}_{2}$ \\
\hline Forest residue & 20.7 & 47.6 & 10.2 & 5.1 & 3.0 & 7.2 & 1.4 & 2.9 & 1.6 & 0.4 \\
\hline Sawdust & 26.2 & 44.1 & 10.8 & 2.3 & 4.5 & 5.3 & 1.8 & 2.1 & 2.5 & 0.4 \\
\hline Wheat straw & 50.4 & 8.2 & 24.9 & 3.5 & 1.54 & 2.7 & 0.88 & 4.2 & 3.5 & 0.09 \\
\hline Rice husks & 94.5 & 0.97 & 2.3 & 0.54 & 0.21 & 0.19 & 0.22 & 0.92 & 0.16 & 0.02 \\
\hline $\begin{array}{l}\text { Chicken litter } \\
\text { Meat and bone } \\
\text { meal }\end{array}$ & 0.62 & 41.2 & 3.2 & 40.9 & 2.4 & 1.38 & 0.25 & 4.2 & 6.4 & 0.01 \\
\hline $\begin{array}{l}\text { Biomass } \\
\text { mixture }\end{array}$ & 34.8 & 13.2 & 3.1 & 18.1 & 11.4 & 2.3 & 10.4 & 4.6 & 1.25 & 0.95 \\
\hline $\begin{array}{l}\text { Demolition } \\
\text { wood }\end{array}$ & 36.3 & 21.4 & 7.0 & 5.1 & 9.7 & 4.8 & 7.3 & 4.1 & 2.8 \\
\hline
\end{tabular}




\begin{tabular}{|l|l|l|l|l|l|l|l|l|l|l|}
\hline $\begin{array}{l}\text { Furniture } \\
\text { waste }\end{array}$ & 57.2 & 13.8 & 3.7 & 0.5 & 12.1 & 3.3 & 5.6 & 0.99 & 2.3 & 0.5 \\
\hline $\begin{array}{l}\text { Mixed waste } \\
\text { paper }\end{array}$ & 28.6 & 7.6 & 0.16 & 0.2 & 53.5 & 2.4 & 0.82 & 1.7 & 0.54 & 4.4 \\
\hline $\begin{array}{l}\text { Greenhouse } \\
\text { plastic waste }\end{array}$ & 28.4 & 25.8 & 9.7 & 3.8 & 3.9 & 5.7 & 18.4 & 2.7 & 0.8 & 0.81 \\
\hline $\begin{array}{l}\text { Refuse- } \\
\text { derived fuel }\end{array}$ & 38.7 & 26.8 & 0.23 & 0.77 & 14.5 & 6.5 & 6.3 & 3.0 & 1.36 & 1.9 \\
\hline $\begin{array}{l}\text { Sewage } \\
\text { sludge }\end{array}$ & 33.3 & 13.0 & 1.6 & 15.9 & 12.9 & 2.5 & 15.7 & 2.1 & 2.3 & 0.8 \\
\hline $\begin{array}{l}\text { Peat } \\
\text { Coal }\end{array}$ & 37.5 & 10.0 & 1.1 & 2.8 & 20.1 & 2.1 & 13.8 & 12.1 & 0.1 & 0.31 \\
\hline $\begin{array}{l}\text { Lignite } \\
\text { Sub- } \\
\text { bituminous } \\
\text { coal }\end{array}$ & 54.9 & 6.6 & 1.6 & 0.5 & 23.2 & 1.8 & 6.9 & 3.5 & 0.82 & 1.05 \\
\hline $\begin{array}{l}\text { Bituminous } \\
\text { coal }\end{array}$ & 56.1 & 4.9 & 1.6 & 0.22 & 24.8 & 1.6 & 6.7 & 2.2 & 0.77 & 1.15 \\
\hline
\end{tabular}

\section{Operating problems during FB waste incineration}

\subsection{Agglomeration, sintering and de-fluidization}

A FBC operates with a selected bed material (mostly silica sand, and/or mixtures of sand and combustion ash), of a given average particle size, and at such a gas velocity that optimum mixing and heat transfer are achieved. Common ranges of operating conditions have been described in Section 2 . This gas velocity and the corresponding gas flow rate can only be changed within certain limits to e.g. avoid excessive carry-over or to operate the FB in the slugging regime, where bubbles of large diameter cause significant pressure fluctuations in the FB. Although a limited particle growth can hence be tolerated, segregation and subsequent de-fluidization are likely to occur if the particle size exceeds the allowable maximum in view of bed mixing [150]. 
The problems of high-temperature FBC de-fluidization due to agglomeration, sintering or other particle-growth phenomena have been investigated and reported by numerous research teams, both for lab-scale and full-scale combustors. Sintering and agglomeration are often interchangeably used to describe the same resulting effect i.e. the increasing particle size of the bed material due to specific operating parameters; the mechanisms of agglomeration and sintering are however different.

Agglomeration is often the result of the in-bed formation of low melting point eutectic mixtures through the reaction of mostly alkali compounds of the waste feed with the silica bed materials: chemical transformations play an important role, and $\mathrm{Na}$ and $\mathrm{K}$ are the main alkali metals responsible for agglomeration, whereas calcium is a known inhibitor. The ratio $\mathrm{Ca} /(\mathrm{K}+\mathrm{Na})$ is hence presented as a useful indicator for the risk of agglomeration in a FBC. Agglomeration can already occur at relatively low temperatures. The underlying mechanisms will be discussed in Section 4.2.

Sintering of the bed materials can also cause particle growth if the bed material is allowed to reach its sintering temperature, due to e.g. a non-uniform temperature and local hot spots in the bed.

Agglomeration can however also occur as a result of liquid and/or salt bridges (near the feeding point of wet feed), or can be due to aggregate formation of the bed material with the char (i.e. the carbonaceous residue remaining after combustion) or with partly burned polymers.

Whereas sintering and agglomeration result in an increasing particle size of the bed material and/or residual ash, attrition reduces the particle size. Attrition of the bed material (sand or similar inert material) is normally limited to an insignificant amount (less than $50 \mathrm{~kg} /$ week of bed material that is lost in a large-scale fluidized bed 
incinerator). Attrition of the waste being fed is more important and needs to be considered with the design of the freeboard to guarantee an acceptable burn-out, as dealt with in Section 2.6.1 of this paper.

Since the particle growth of the bed material will eventually (on a very short or longer time scale) lead to de-fluidization, an appropriate prediction of the agglomeration/sintering characteristics is essential, and preferably coupled with online follow-up measurements. De-fluidization will lead to a required shutdown of the FBC. Preventive and counteracting measures may need to be taken, such as reducing the operating temperature, reducing the feed rate, selecting alternative bed materials, or using additives to avoid the formation of a sticky layer by preferentially forming other components with higher melting points. These single or combined measures will also be dealt with in the following sections.

Since the waste incinerated in a FBC usually contains organic and inorganic compounds, the ash content and its chemical composition, as well as char-residue from incomplete burn-out, are a strong function of the waste species under scrutiny. The most important elements in the ash are O, $\mathrm{Ca}, \mathrm{K}, \mathrm{Si}, \mathrm{Mg}, \mathrm{Al}, \mathrm{S}, \mathrm{Fe}, \mathrm{P}, \mathrm{Cl}, \mathrm{Na}$, $\mathrm{Mn}$, and Ti [151]. An extensive literature survey [23, 30, 151-161] and own analyses have provided detailed data on the ash composition for some types of biomass. These are shown in Table 11 along with data for fossil fuel and other potential FBCfeedstock.

Table 11: Major gaseous pollutants: concentrations formed in the combustor, recommended abatement techniques and typical concentrations to be expected in the emitted flue gas of commercial FBC boilers incinerating MSW. 


\begin{tabular}{|c|c|c|c|c|}
\hline Pollutant & $\begin{array}{l}\text { Reference } \\
\text { and waste } \\
\text { type }\end{array}$ & $\begin{array}{l}\text { Concentration } \\
\text { formed } \\
\mathrm{mg} / \mathrm{m}^{3}\end{array}$ & $\begin{array}{l}\text { Recommended } \\
\text { abatement } \\
\text { technique }\end{array}$ & $\begin{array}{l}\text { Expected emission } \\
\text { concentration } \\
\mathrm{mg} / \mathrm{m}^{3} \text { [115-116, } \\
135]\end{array}$ \\
\hline $\mathrm{CO}$ & $\begin{array}{l}\text { [57] Paper and } \\
\text { plastic waste + } \\
\text { coal } \\
\text { [58] Plastic, paper, } \\
\text { wood and textile } \\
\text { blend } \\
\text { [63] Meat\&Bone } \\
\text { meal + coal } \\
\text { [67] Peach stone } \\
\text { Apricot stone } \\
\text { [71] Rice husk + } \\
\text { coal }\end{array}$ & $\begin{array}{l}120-520^{*} \\
150-300 \\
200-1400^{*} \\
1500 \\
6500-13000 \\
60-30 *^{*}\end{array}$ & $\begin{array}{l}\text { Complete combustion by } \\
\text { - } \quad \text { sufficient residence } \\
\text { time (design, gas } \\
\text { velocity) } \\
\text { - } \quad \text { optimum excess air } \\
\text { ratio by injection of } \\
\text { secondary air }\end{array}$ & $14-40$ \\
\hline $\mathrm{HCl}$ & $\begin{array}{l}\text { [56] RDF + coal } \\
\text { [64] Meat\&Bone } \\
\text { meal + coal } \\
\text { [74] PVC + coal }\end{array}$ & $\begin{array}{l}220-1600^{*} \\
25-150 \\
90-250^{*}\end{array}$ & 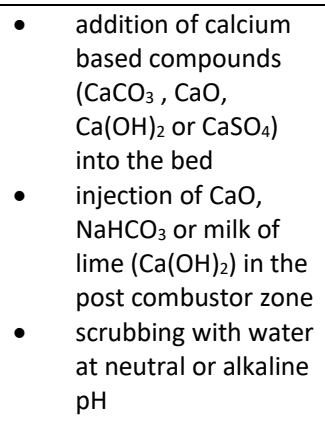 & $0.1-8$ \\
\hline $\mathrm{SO}_{\mathrm{x}}$ & $\begin{array}{l}\text { [57] Paper and } \\
\text { plastic waste + } \\
\text { coal } \\
\text { [58] Plastic, paper, } \\
\text { wood and textile } \\
\text { blend } \\
\text { [63] Meat\&Bone } \\
\text { meal + coal } \\
\text { [64] Meat\&Bone } \\
\text { meal + coal } \\
\text { [67] Coal } \\
\text { [71] Rice husk + } \\
\text { coal } \\
\text { [74] PVC + coal }\end{array}$ & $\begin{array}{l}400-920^{*} \\
20-80 \\
650-800^{*} \\
30-1000 \\
2300 \\
10-300^{*} \\
70-250^{*}\end{array}$ & $\begin{array}{l}\text { Same techniques as for the } \\
\text { abatement of } \mathrm{HCl}\end{array}$ & $1-1.6$ \\
\hline $\mathrm{NO}_{\mathrm{x}}$ & $\begin{array}{l}\text { [56] RDF + coal } \\
\text { [57] Paper and } \\
\text { plastic waste + } \\
\text { coal } \\
\text { [63] Meat\&Bone } \\
\text { meal + coal } \\
\text { [58] Plastic, paper, } \\
\text { wood and textile } \\
\text { blend } \\
\text { [67] Peach or }\end{array}$ & $\begin{array}{l}270-380^{*} \\
220-550^{*} \\
470-950^{*} \\
80-240 \\
200-300\end{array}$ & $\begin{array}{l}\text { - } \text { Air staging to obtain } \\
\text { O2 lean primary } \\
\text { combustion and 3\% } \\
\text { O2 excess in } \\
\text { secondary } \\
\text { combustion zone } \\
\text { - SCR or SNCR }\end{array}$ & $90-150$ \\
\hline
\end{tabular}




\begin{tabular}{|c|c|c|c|c|}
\hline & Apricot stone & & & \\
\hline PM10 & $\begin{array}{l}\text { [54] Meat\&Bone } \\
\text { meal + coal } \\
\text { [69] Different } \\
\text { biomass + Coal }\end{array}$ & $\begin{array}{l}88-392 \\
250-1000\end{array}$ & $\begin{array}{l}\text { Electrostatic precipitator } \\
\text { or baghouse filter }\end{array}$ & $0.6-1$ \\
\hline PCDD/Fs & $\begin{array}{l}\text { [56] RDF + coal } \\
\text { [64] Meat\&Bone } \\
\text { meal } \\
\text { [69] Coal } \\
\text { Meat\&Bone meal } \\
\text { Straw pellets } \\
\text { [137] Wood + PVC } \\
\text { pellets } \\
\text { [138] Salt-laden } \\
\text { waste wood }\end{array}$ & $\begin{array}{l}0.39-0.45 \mathrm{ngTEQ} / \mathrm{m}^{3} \\
0.496 \mathrm{ng} \mathrm{I-TEQ} / \mathrm{m}^{3} \\
1.1 \mathrm{ng} \mathrm{I-TEQ} / \mathrm{m}^{3} \\
549 \mathrm{ng} \mathrm{I-TEO} / \mathrm{m}^{3} \\
42950 \mathrm{ng} \mathrm{I}-\mathrm{TEO} / \mathrm{m}^{3} \\
0.03-0.11 \mathrm{ngTEQ} / \mathrm{m}^{3} \\
<1-120 \mathrm{ngTEO} / \mathrm{m}^{3}\end{array}$ & $\begin{array}{ll}- & \text { Assuring complete } \\
\text { combustion (see CO) } \\
\text { - } \quad \text { Limitation of flue gas } \\
\text { residence time in } 200 \\
-400^{\circ} \mathrm{C} \text { temperature } \\
\text { zone } \\
\text { - Adsorption on } \\
\text { injected reagents e.g. } \\
\text { activated carbon } \\
\text { powder } \\
\text { Catalytic oxidation }\end{array}$ & $0.001-0.01 \mathrm{ngTEQ} / \mathrm{m}^{3}$ \\
\hline PAHs & $\begin{array}{l}\text { [137] Wood + PVC } \\
\text { pellets } \\
\text { [141] Coconut } \\
\text { shells }\end{array}$ & $\begin{array}{l}2.74-6.92 \mu \mathrm{g} / \mathrm{m}^{3} \\
9588-43123 \mu \mathrm{g} / \mathrm{m}^{3}\end{array}$ & $\begin{array}{l}\text { Same techniques as for the } \\
\text { abatement of PCDD/Fs }\end{array}$ & $0.80-7.4 \mu \mathrm{g} / \mathrm{m}^{3}$ \\
\hline
\end{tabular}

* calculated from ppm

Ash and/or char not only cause agglomeration and de-fluidization, but also lead to deposits in ducts or on boiler tubes where they reduce heat transfer, and can cause severe corrosion at high temperature [155].

\subsection{Fundamentals of agglomeration}

\subsubsection{Mechanisms of agglomeration}

In the context of the present paper, agglomeration is considered as the "sticking" of particles "stick" together and inducing particle growth due to:

- $\quad$ physical or chemical forces between individual particles.

- $\quad$ chemical or physical modifications of the solids triggered by specific process conditions. 
- $\quad$ the presence of binding substances that adhere chemically or physically to the solid surfaces forming an inter-particle bridge.

Due to the particle growth, the reduced mixing at the given operating gas velocity can lead to segregation with poor combustion at the bottom of the bed (lower temperature) and excessive combustion in the upper bed region with associated higher temperatures, thus increasing the risk of further agglomeration and even sintering of the bed material. The partial, localized segregation can induce channeling of the bed, as indicated by an abrupt decrease in bed pressure drop. Finally, the operation must be stopped and the bed material emptied and replaced.

Normally, quartz sand is used as bed material in FBCs. Öhman et al. [162] proposed a three-step agglomeration mechanism based on experimental investigations, and illustrated in Figure 16.

Step 1: Ash is deposited on the surface of the bed material by combined attachment of small particles on the bed particle surface, condensation of gaseous alkali species (e.g. $\mathrm{KCl}, \mathrm{KOH}, \mathrm{K}_{2} \mathrm{SO}_{4}$ ) and chemical reaction of alkali metals on the bed material surface.

Step 2: Continuous deposition of ash on the bed particles proceeds and the inner layer of the coating is probably homogenized and strengthened via sintering.

Step 3: Partial melting continues along with and further agglomeration of covered particles, controlled by adhesive inter-particle forces. 

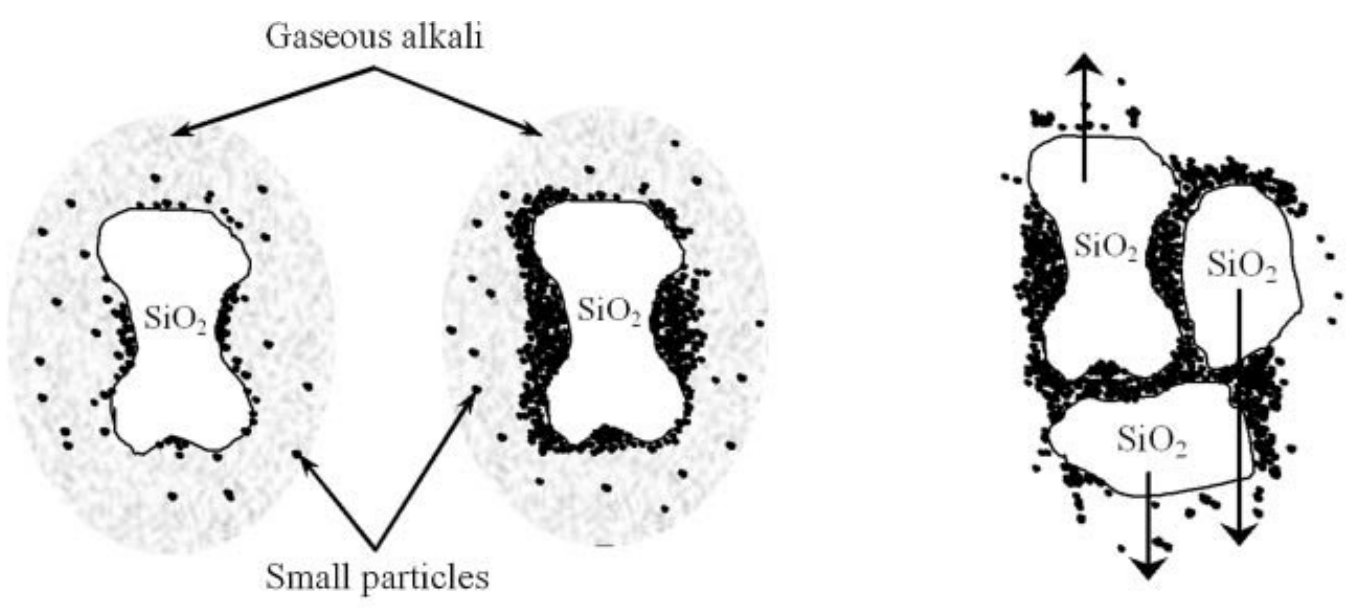

Deposition via; i) attachment of small particles ii) condensation, and iii) chemical reaction

Sintering and homogenization

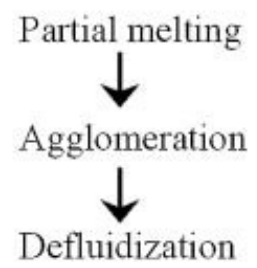

time

Increasing bed particle surface temperature

Figure 16. Agglomeration mechanisms [163].

The chemical composition of the coating layer affects its melting temperature. When the coating has built up an adequate amount of the molten phase, it develops the adhesive forces that can cause bed agglomeration, which in the most severe case results in de-fluidization. The first two steps cause the layer to grow outward on the particles and all the elements in the layer originate from the waste feed material. In the third step, the layer extends as the reactive elements react with the bed particles. In all three cases, growth is hampered by abrasion of the layer by the shear action of bed particles $[21,163]$. As the deposition on the bed particles proceeds with time, the inner layer of the coating is homogenized and strengthened via sintering, started as neck growth between the particles, resulting at first in a porous network of particles attached to each other, however progressively densifying into a continuous, nonporous coarser particle. 
Additional less important mechanisms of forming agglomerates have been identified, i.e. through deposition of fine sand particles onto a char particle [46].

\subsubsection{The chemistry of agglomeration}

The majority of the agglomeration phenomena at high temperature is induced by chemical reactions that produce cohesive particles, low-melting ash forming the dominant contribution [164]. Sulfur, chlorine, iron, phosphorus, vanadium, alkali and alkaline earth metals take part in the agglomeration reactions, as illustrated in the examples below.

If a waste sludge containing sulfur is incinerated or if high-sulfur fuel is used as auxiliary fuel, the eutectic melting temperature of combined chlorides or sulfates can be quite low. A $65 / 35$ mixture of $\mathrm{Na}_{2} \mathrm{SO}_{4}$ and $\mathrm{NaCl}$ has a melting point of $621^{\circ} \mathrm{C}$, compared to $884{ }^{\circ} \mathrm{C}$ for $\mathrm{Na}_{2} \mathrm{SO}_{4}$ and $801^{\circ} \mathrm{C}$ for $\mathrm{NaCl}$. Magnesium has a similar effect, and a $60 / 40$ mixture of $\mathrm{Na}_{2} \mathrm{SO}_{4}$ and $\mathrm{MgSO}_{4}$ melts at $660^{\circ} \mathrm{C}$ [165].

Chlorine plays a very important role in terms of the formation of alkali silicates as it increases the volatility (or mobility) of the alkali metals. Alkali metals can be released them as alkali chlorides and hydroxides in the gas phase. The chlorine concentration often determines the amount of alkali metal vaporized during combustion more strongly than the alkali metal concentration itself. In most cases, chlorine appears to play a shuttle role, facilitating the transport of alkali metals from the fuel to the surface. In the absence of sulfur, chlorides often reside on the surface [46]: the presence of chlorine in the feed leads to increased deposition rates, while the presence of sulfur suppresses deposition.

It has also been mentioned that an excess of sulfur in the flue gas prevents fouling by facilitating the sulfation of alkali chlorides and making the ash less sticky: According 
to equation 8 , the sulfation reaction is complete when the (starting) $\mathrm{Cl} / \mathrm{S}$ molar ratio is below 2, with higher ratios corresponding to an excess of chloride.

$2 \mathrm{MCl}+\mathrm{SO}_{2}+1 / 2 \mathrm{O}_{2}+\mathrm{H}_{2} \mathrm{O} \rightarrow \mathrm{M}_{2} \mathrm{SO}_{4}+2 \mathrm{HCl}$, where $\mathrm{M}=\mathrm{K}$ or $\mathrm{Na}(8)$

Assuming that sulfation reactions are correlated with lower deposition rates, it would ideally be expected that deposition is reduced for $\mathrm{Cl} / \mathrm{S}$ below $2 \mathrm{~mol} / \mathrm{mol}$. It is however possible that less $\mathrm{S}$ is available than anticipated from the fuel ash analysis since $\mathrm{S}$ may be captured by $\mathrm{Ca}^{2+}$ compounds. Another explanation for the excess requirement of $S$ could be kinetic restraints of the sulfating reaction, especially during the intermediate step of $\mathrm{SO}_{3}$ formation [166-167]. A recent patent claims that spraying a solution of ammonium sulfate into the flue gas prevents deposit formation [168].

If sufficient $\mathrm{Fe}_{2} \mathrm{O}_{3}$ is present in the ash, the rate of formation of agglomerates may be reduced since $\mathrm{Fe}_{2} \mathrm{O}_{3}$ reacts preferentially with the alkali compounds present in the bed according to equation 9:

$\mathrm{Fe}_{2} \mathrm{O}_{3}+\mathrm{M}_{2} \mathrm{O} \rightarrow \mathrm{M}_{2} \mathrm{Fe}_{2} \mathrm{O}_{4}$ and $\mathrm{Fe}_{2} \mathrm{O}_{3}+\mathrm{M}_{2} \mathrm{CO}_{3} \rightarrow \mathrm{M}_{2} \mathrm{Fe}_{2} \mathrm{O}_{4}+\mathrm{CO}_{2}(9)$

(where $\mathrm{M}$ can be $\mathrm{K}$ or $\mathrm{Na}$ ).

Alkali metals are hence no longer available, whilst compounds with melting temperatures in excess of $1135^{\circ} \mathrm{C}$ are produced [169]. $\mathrm{Fe}_{2} \mathrm{O}_{3}$ can moreover convert sodium or potassium silicate glass into a high-melting-point crystalline form by equation $10[165,170]$ :

$\mathrm{Na}_{2} \mathrm{O} \cdot 3 \mathrm{SiO}_{2}+\mathrm{Fe}_{2} \mathrm{O}_{3}+\mathrm{SiO}_{2} \rightarrow \mathrm{Na}_{2} \mathrm{O} \cdot \mathrm{Fe}_{2} \mathrm{O}_{3} \cdot 4 \mathrm{SiO}_{2}$ (acmite, with melting point $955^{\circ} \mathrm{C}$ ) 
Meta-phosphate of sodium $\left(\mathrm{NaPO}_{3}\right)$ and/or of potassium $\left(\mathrm{KPO}_{3}\right)$ can be formed if a sludge contains organic phosphorus: these meta-phosphates melt at low temperatures $\left(682^{\circ} \mathrm{C}\right.$ and $807^{\circ} \mathrm{C}$, respectively). Scale formation in the exhaust gas duct or on the wall of the reactor occurs by a two-step reaction. In the first step, iron phosphate reacts with calcium chloride in the solid phase to produce calcium phosphate with the release of gaseous iron chloride according to equation 11 :

$2 \mathrm{FePO}_{4(\mathrm{~s})}+3 \mathrm{CaCl}_{2(\mathrm{~s})} \rightarrow \mathrm{Ca}_{3}\left(\mathrm{PO}_{4}\right)_{2(\mathrm{~s})}+2 \mathrm{FeCl}_{3(\mathrm{~g})}(11)$

In the second step, gaseous iron chloride reacts with water vapor in the reactor freeboard and exhaust gas duct to form specular hematite, releasing hydrochloric acid, according to equation 12 :

$2 \mathrm{FeCl}_{3(\mathrm{~g})}+3 \mathrm{H}_{2} \mathrm{O}_{(\mathrm{g})} \rightarrow \mathrm{Fe}_{2} \mathrm{O}_{3}+6 \mathrm{HCl}_{(\mathrm{g})}(12)$

The precipitated product forms scales and layers of red deposits in the duct and on the roof dome of the combustor [165]. The formed $\mathrm{HCl}$ is moreover a source of concern, both for its corrosive character and towards stack emissions (Section 3.2.2.).

Heavy metal elements (such as vanadium and nickel) can significantly lower the ashmelting point when petroleum coke is co-fired with limestone in CFB boilers, leading to agglomeration problems in the combustor or loop seal of a CFBC due to the formation of molten ash compounds. Increasing the amount of limestone cannot only enhance the effect of desulfurization, but also catch vanadium into ash. The vanadium in the deposits is present as high melting point calcium vanadates and, therefore, unlikely to form low melting point eutectic mixtures [171-172]. 
The alkaline earth metals, Mg and Ca have a dual effect, since they can either inhibit or promote agglomeration. At low ( $\mathrm{Na}$ or $\mathrm{K}) / \mathrm{Mg}$ and ( $\mathrm{Na}$ or $\mathrm{K}$ )/Ca molar ratios, $\mathrm{Mg}$ and Ca significantly inhibit agglomeration. This inhibition diminishes with increasing concentration of $\mathrm{Na}$, and is no longer apparent at a molar ratio of $(\mathrm{Na}$ or $\mathrm{K}) / \mathrm{Mg}$ or $(\mathrm{Na}$ or $\mathrm{K}) / \mathrm{Ca}$ in excess of 2 . The final effect is a function of competing reactions between the bed material $\left(\mathrm{SiO}_{2}\right)$ and the alkali and alkaline earth metals, forming either e.g. potassium silicate (with melting point approximately $750{ }^{\circ} \mathrm{C}$ ) or calcium silicate (melting point approximately $1000^{\circ} \mathrm{C}$ ) [163]. The ratio of $\mathrm{Ca} /(\mathrm{Na}+\mathrm{K})$ in the fuel can hence be used as an index for agglomeration reduction [26], with a higher value reducing the probability of agglomeration.

$\mathrm{NaCl}$ and $\mathrm{KCl}$ melt at normal operating conditions of the $\mathrm{CFB}\left(780-900{ }^{\circ} \mathrm{C}\right): \mathrm{NaCl}$ and $\mathrm{KCl}$ have melting points of $801^{\circ} \mathrm{C}$ and $776^{\circ} \mathrm{C}$, respectively. They moreover have significant vapor pressures at these temperatures and form eutectic mixtures with ash or bed material. Potassium is the dominant source of alkali in most solid biofuels. It has been observed in biomass-fired FBCs, especially when feeding herbaceous biomass, that the bond of agglomerates is mainly composed of silicon and potassium, sometimes with a small amount of calcium, indicating that compounds consisting of $\mathrm{K}_{2} \mathrm{O}-\mathrm{SiO}_{2}$ and/or $\mathrm{K}_{2} \mathrm{O}-\mathrm{CaO}-\mathrm{SiO}_{2}$ are formed. The ash characteristics of biomass differ from those of coal, with biomass ashes normally dominated by silicon, potassium and calcium whilst containing little aluminium (Table 11). Potassium is dispersed in biomass in different forms, e.g. organo-metallics and salts, while silicon occurs primarily as hydrated silica grains. During combustion, potassium is likely to be volatilized as $\mathrm{KCl}$ if chlorine is present in the fuel. Without chlorine, $\mathrm{KOH}, \mathrm{K}_{2} \mathrm{O}$, $\mathrm{K}_{2} \mathrm{SO}_{4}$ or $\mathrm{K}_{2} \mathrm{CO}_{3}$ may be formed. Alkali and alkaline earth metal ions associate primarily with sulfate, carbonate and/or chloride ions during ash formation. The 
presence of $\mathrm{SiO}_{2}$ in herbaceous biomass can significantly affect the partition of $\mathrm{K}$ released to gas phase and fixed in the solid phase. If the bed material of a FBC is silica sand or if there is $\mathrm{SiO}_{2}$ present, as in waste sludge, $\mathrm{NaCl}$ combined with water vapor from the bed will react with silica and form sodium silicate glass according to equation 13:

$3 \mathrm{SiO}_{2}+2 \mathrm{NaCl}+\mathrm{H}_{2} \mathrm{O} \rightarrow \mathrm{Na}_{2} \mathrm{O}-3 \mathrm{SiO}_{2}+2 \mathrm{HCl}(13)$

$\mathrm{KCl}$ is vitrified in a similar manner. The alkali oxides or salts can also react with $\mathrm{Si}$ compounds of the bed material according to equation 14 :

$2 \mathrm{SiO}_{2}+\mathrm{Na}_{2} \mathrm{CO}_{3} \rightarrow \mathrm{Na}_{2} \mathrm{O}-2 \mathrm{SiO}_{2}+\mathrm{CO}_{2}(14)$

Eutectics with low melting points are formed. The eutectic melting point of $\mathrm{K}_{2} \mathrm{O}-\mathrm{CaO}-$ $\mathrm{SiO}$ is even lower. The silica sand bed may start to get sticky at a bed temperature as low as $630^{\circ} \mathrm{C}$. The formation of liquid phase on the sand particles will interfere with fluidization. Experience indicates that the upper acceptable limit of liquid phase in the bed material is $1 \mathrm{wt} \%$. [164-165, 169, 27, 173]. The melting of $\mathrm{K}_{2} \mathrm{O}-\mathrm{SiO}_{2}$ compounds is clearly identified as the coating layer on the sand surfaces, which causes the formation of agglomerates, leading possibly to de-fluidization.

It is also very likely that agglomerates are initiated from burning char particles, whose surface temperature is normally 50 to $100^{\circ} \mathrm{C}$ higher than the average bed temperature [174], with coating of a bed particle as result. Thermodynamic equilibrium calculations show that potassium silicates are the main stable condensed phase potassium species, which agrees with the analysis of the agglomerate samples [175]. 
Gas-solid reactions may alter the composition of ash. For example, sulfur dioxide present in the gas phase at relatively low temperatures $\left(<800^{\circ} \mathrm{C}\right)$ will react with potassium forming $\mathrm{K}_{2} \mathrm{SO}_{4}$, which has a higher melting temperature than the eutectics of silicates. In addition, gas-gas reactions may change the gas-phase composition and route of formation of sub-micron particles (aerosols). A typical example is given as equation 15:

$2 \mathrm{KCl}+\mathrm{SO}_{2}+\mathrm{H}_{2} \mathrm{O}+1 / 2 \mathrm{O}_{2} \rightarrow \mathrm{K}_{2} \mathrm{SO}_{4}+2 \mathrm{HCl}(15)$

Reduced amounts of gas-phase $\mathrm{KCl}$ may decrease the probability of depositing potassium compounds on the sand particles by condensation [27].

The sample composition data of Figure 17a [176] can be grouped in three welldefined zones in the ternary diagram of the $\mathrm{K}_{2} \mathrm{O}-\mathrm{CaO}-\mathrm{SiO}_{2}$ system. The temperatures at which a melt phase starts to form are indicated in the phase diagram of Figure $17 \mathrm{~b}$ [177]. Figure $17 \mathrm{~b}$ is a $2 \mathrm{D}$ representation of a $3 \mathrm{D}$ ternary phase diagram. It indicates, as a function of the concentration (\%) of the three considered components, the "solidus" and the "liquidus" temperatures. The solidus temperature is the temperature at which a particle with a certain composition starts to form a solid phase-liquid phase system. Above the liquidus temperature, there is only a liquid phase. In a 3D ternary phase diagram, the "solidus" surface indicates the solidus temperature of a system as a function of the concentration of the three considered components. Analogously, the "liquidus" surface indicates the liquidus temperature as a function of the concentration of the three considered components.

A 2D- ternary phase diagram as shown in Figure 17b consists of a projection of liquidus and solidus surfaces. The liquidus surface is projected as a contour plot (curved lines) with an indication of the temperatures. The projection of the solidus 
surfaces consists of various triangles (straight "• - " lines). The solidus temperature then equals the lowest liquidus temperature in that triangle. In a eutectic point, a single phase transition from solid to liquid takes place, thus corresponding to equal liquidus and solidus temperature. If a eutectic point is present in a solidus surface triangle, the solidus temperature equals the melting temperature of the eutectic.

Samples with visible molten material are all confined in the low $\mathrm{CaO}$ region of the diagram (Figures $17 \mathrm{a}$ and $17 \mathrm{~b}$ ) with a $\mathrm{K}_{2} \mathrm{O}$ content in the range $5-25 \%$. This zone is clearly located in the lower right section of the phase diagram, where low-melting point eutectics appear. Samples showing a sand surface without visible molten material are confined in the nearby region on the right, with a $\mathrm{K}_{2} \mathrm{O}$ content in the range $0-10 \%$ and a $\mathrm{SiO}_{2}$ content above $90 \%$. In this region, silica sand is the solid phase, and the reverse lever rule shows that the amount of liquid phase is low. On the other hand, the composition of the ash structures deposited on the sand surface (without melt formation) is situated in a region with a moderate-to-high $\mathrm{CaO}$ content $(20-80 \%)$. A correlation between the degree of melting of the ash structures and the $\mathrm{CaO}$ content was found: the lower the $\mathrm{CaO}$ fraction, the higher the melting degree of the ash sample. This is in agreement with Figure 17b, showing higher melt temperatures for $\mathrm{CaO}$-rich systems. 

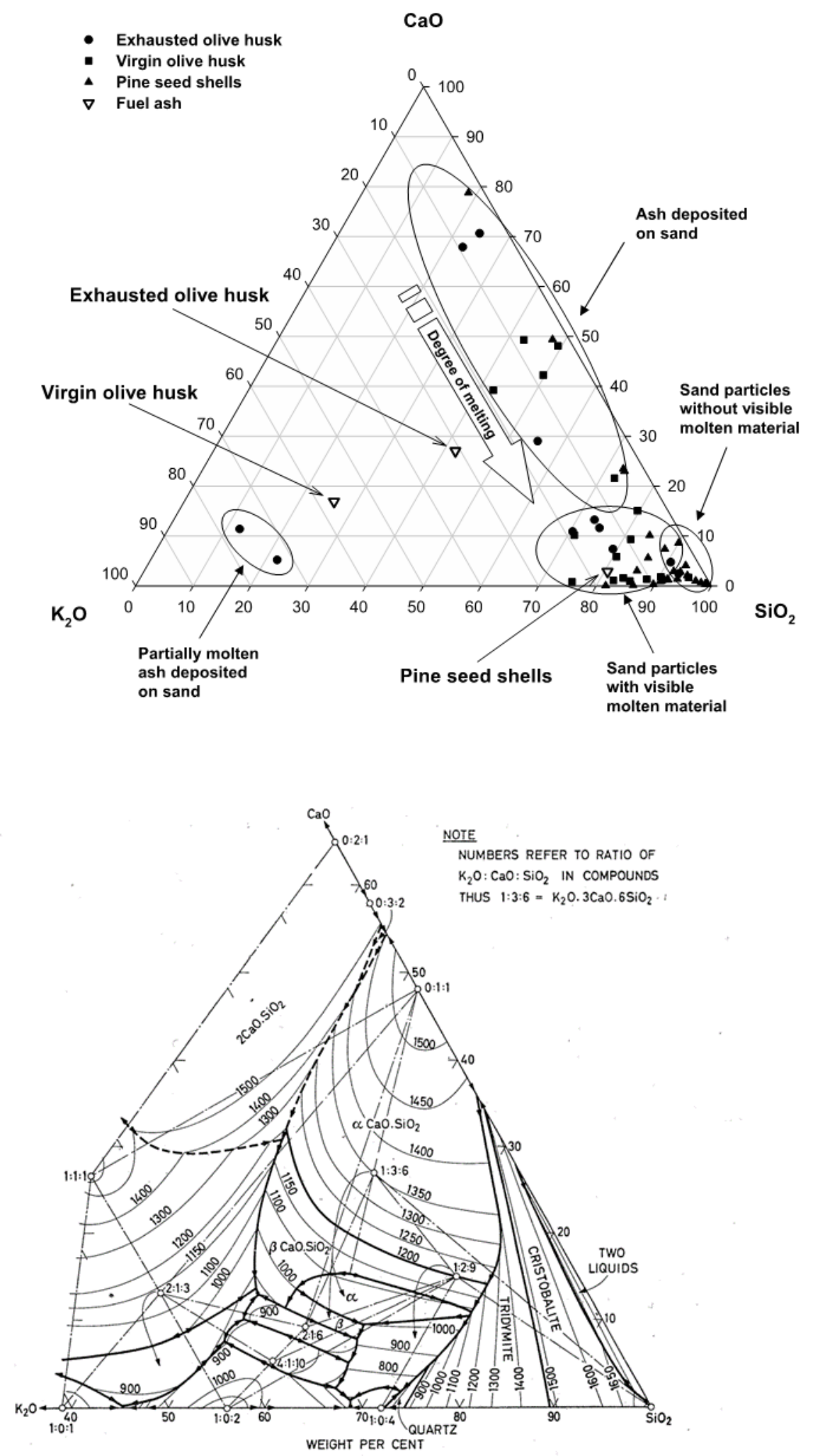

Figure 17: Ternary diagram of the system $\mathrm{K} 2 \mathrm{O}-\mathrm{CaO}-\mathrm{SiO} 2$ showing the measured composition of different zones on the surface of agglomerated samples, obtained by semi-quantitative SEM/EDX spot analyses [179] 
The results support the ash deposition-melting mechanism: the ash released by burning char particles inside the agglomerate is quantitatively deposited on the sand surface and then gradually embedded in the melt. The low-melting point compounds ( $\mathrm{K}$ and $\mathrm{Na}$ ) migrate towards the sand surface enriching the outermost layer, while the ash structure is progressively depleted of these compounds (and enriched with $\mathrm{Ca}$ and $\mathrm{Mg}$ ). From the different ternary diagrams presented in literature [178] it is evident that the silica group $\left(\mathrm{SiO}_{2}\right)$, alkaline earths $(\mathrm{CaO}$ and $\mathrm{MgO})$ and alkali groups $\left(\mathrm{K}_{2} \mathrm{O}\right.$ and $\mathrm{Na}_{2} \mathrm{O}$ ), representing a major fraction of the ash content, are the critical eutectic compounds. Sintering is unlikely when $\mathrm{CaO}>50 \%$, as in cork, poplar, brassica and thistle, or if $\mathrm{SiO}_{2}>50 \%$ along with $\mathrm{K}_{2} \mathrm{O}>15 \%$, as in eucalyptus, rockrose and olive trees [178]. Although ternary phase diagrams are useful to predict the ash behavior, there are no clear correlations to plot concentrations of the melting ash-elements against the eutectic temperatures, because the chemistry involved in ash agglomeration or sintering is complex and cannot be clarified by the presence of only one or two components.

\subsection{Fundamentals of sintering}

The onset or initial sintering temperature, when the particles themselves begin to sinter by softening of surface and the formation of inter-particle bonds, is often lower than the fusion temperature of the bulk material and is called the "minimum sintering temperature".

Ash sintering may cause problems in FBCs, as it densifies particles to a compacted hard mass. It can form bed agglomerates in the furnace and in the cyclone, and can lead to plugging of the cyclone return leg. In the worst case, a complete bed defluidization may occur. Increasing the fluidizing velocity can prevent de-fluidization. Increasing the initial size of the bed particles, accompanied by an increased 
operating velocity, reduces the above phenomena, due both to a lower surface area presented, and to higher shear forces generated, capable of breaking initial bonds [179].

There are 3 types of sintering i.e. sintering caused by partial melting ${ }_{2}$ also described as reactive liquid sintering, viscous flow sintering, and chemical reaction sintering. In biomass-fired FBC boilers, partial melting is considered as the main mechanism leading to bed agglomeration: alkali compounds can melt into low-viscous melts, and act like a bonding agent. Sintering, in this case strongly depends upon the amount of the melt, which in turn is a function of temperature and chemical composition. The amount of liquid phase controls the stickiness of the particles and the agglomeration of the particles. The clinker bridges formed were identified to be associated with the elements $\mathrm{Al}, \mathrm{Fe}, \mathrm{V}, \mathrm{K}, \mathrm{Na}, \mathrm{S}, \mathrm{Ni}$, and $\mathrm{Si}[46,180-182]$.

A highly viscous melt, referred to as viscous flow sintering, may occur in the presence of silica, common bed material in FBCs. This kind of melt poses the greatest problem due to the formation of a vitrified phase which does not crystallize upon cooling, acting like a super cooled liquid phase. Inorganic alkali components from the fuel, mainly $\mathrm{K}$ and $\mathrm{Na}$, can be a source for agglomeration by the formation of low-melting silicates with the bed silica. As a consequence, the sand particles become coated with an adhesive layer. Sand particles with a sticky surface then grow towards larger agglomerates due to the formation of permanent bonds upon collisions. [181, 183].

Chemical reaction sintering occurs when reaction between the particles produces a new compound which forms necks between the particles, as seen e.g. in gas-solid chemical reaction sintering in pressurized FBCs with limestone injection for flue gas 
$\mathrm{SO}_{2}$ removal. Laboratory experiments revealed that if $\mathrm{CaO}$ could react with a gas such as $\mathrm{SO}_{2}$ or $\mathrm{CO}_{2}$, forming $\mathrm{CaSO}_{4}$ or $\mathrm{CaCO}_{3}$ respectively, the particles coalesced, forming a dense and hard material. The sintering temperature decreased to about $600^{\circ} \mathrm{C}$ [181]. This mechanism is also called molecular cramming, an effect described as filling empty spaces, i.e. pores or interstitial spaces, in materials restricted to a given volume by the increase of the molar volume of the reacting components. The (complete) sulfation of $\mathrm{CaO}$ into $\mathrm{CaSO}_{4}$ yields a volume increase of $\sim 40 \%$ and is expected to be the major effect here. This mechanism is taking place in absence of fuel-derived ash, which otherwise could possibly provide discontinuities in the deposits allowing them to break up [171].

Sintering can produce agglomeration, with silica and the heating value of the fuel as important parameters. Based upon this finding, Hulkkonen et al. [184] proposed that the sintering tendency is severe when fuel constituents exceed the following limits:

$\frac{\left(\mathrm{K}_{2} \mathrm{O}+\mathrm{Na}_{2} \mathrm{O}\right)}{\mathrm{SiO}_{2}}>1 ;$ and $\quad \frac{\left(\mathrm{K}_{2} \mathrm{O}+\mathrm{Na}_{2} \mathrm{O}\right)}{\mathrm{HHV}}>0.34$

\subsection{Melt and coating induced agglomeration}

\subsubsection{Agglomeration by liquid bridges}

A specific agglomeration problem occurs if a liquid is slowly added to the FBC and exceeds a threshold limit. If excessively wet biomass is fed into a fluidized bed, first the liquid droplets contact the bed particles in the feed zone before spreading over the particle surface forming wet embryonic agglomerates due to liquid bridges. Defluidization could thus occur near the feed zone. As the liquid dries, bridges are broken, but if the liquid contains dissolved solids like in slurry fuels, the liquid bridges may be converted to solid bridges. If the binding strength of the solid bridges 
exceeds the break-up forces of fluidization, size growth will occur [26]. Uniform feeding of wet feedstock across the FBC cross sectional area is therefore recommended, as further discussed in Section 4.9.

\subsubsection{Melt and coating induced agglomeration}

This phenomenon is somewhat similar in mechanism to agglomeration by liquid bridges. During biomass conversion in a FBC, a large part of the ash leaves the installation as fly ash, while a smaller part remains in the bed. Visser et al. [185] recognized two extreme types of agglomerates. One extreme, Type 2 of Figure 18, results from "melt-induced" agglomeration, where the bed material grains are "glued" together by a melt phase formed from small ash particles, with the same chemical composition as the ash produced at normal operating temperature. The other extreme type of agglomerates, Type 1 in Figure 18, is more commonly observed in commercially operated FBCs using woody fuels and results from coating-induced agglomeration. Here, a uniform coating is formed on the surface of the bed material grains. At certain critical conditions of e.g., coating thickness and/or temperature, neck formation may occur between coatings of individual grains, which initiates the agglomeration. Type 1 is the dominant process in most commercial- scale installations.

(1) Gas phase

Sintering of coating layers

Bed

grain

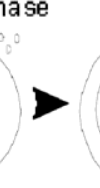

(2)

$$
\text { Ash }
$$
Agglomeration due to (ash)melt formation 
Figure 18. Agglomeration of bed material after formation from the gas phase (1) or melt formation of ash components (2).

A combination of melt-induced agglomeration and coating- induced agglomeration can occur under certain critical conditions. When the coating thickness is sufficiently large or if the temperature exceeds $1000^{\circ} \mathrm{C}$, neck formation may start between the coatings of individual grains, initiating agglomeration. The neck remains in a highly viscous liquid phase [180]. Both types of agglomeration can be observed simultaneously in one bed : a large number of individual particles can stick together to form one larger size agglomerate, or many coarse agglomerates of three to six sand particles can firmly stick together [186].

A specific melt-induced agglomeration can occur when polymers are fed to the FBC. The polymer pellet injected into the FBC is quickly heated up by the high-rate heat transfer: the temperature of the outer shell exceeds the colder temperature of the particle centre and quickly reaches the softening point, so that the outer shell becomes adhesive. A polymer-sand aggregate forms at this initial stage: the core of the aggregate is made of the plastic pellet while the external shell is formed by the sand particles stuck on the adhesive surface of the polymer. An increase in particle temperature over the melting point leads to the cracking of the polymer weaker bonds. The resulting aggregate is made of several layers of sand kept together by the polymer not yet devolatilized (as in the case of PE) or by the sticky carbon residue (as in the case of PET). This means that, depending on the nature of the polymer, and in particular on the presence or not of a sticky carbon residue, the polymer flowing throughout the sand particles can lead to a faster crumbling of the aggregates (as in the case of PE) or can promote the adhesion of several layers of inert material, until the polymeric mass completely flowed throughout the sand (as in 
the case of PET).The first leads to elutriation of fines, the second to agglomeration, which generates aggregates that may grow so large as to lead to operating difficulties and, in some cases, bed de-fluidization [187].

\subsection{The fuel particle temperature as important parameter in de-fluidization problems}

The fuel particle temperature is an important additional parameter besides the average bed temperature; the fuel particle temperature largely depends on the combustion rate, radiation properties and heat/mass transfer in the boundary layer. Based on batch combustion experiments in a lab-scale fluidized bed [175] proposed that the onset of agglomeration takes place around burning char particles. During char combustion, the temperature of the burning char particles is higher than that of the bed, causing the inorganic matter in the char particle to melt and migrate to its surface. Char particles then become very adhesive and capture sand particles upon collision, forming agglomerates and coating the sand surfaces with the sticky melts. The ash deposition on bed particles will be dominated by the fuel particle temperature, whereas the agglomeration of ash-covered bed particles will be dominated by the average bed temperature. Chirone et al. [164] confirmed the presence of ash-layered bed material at an average bed temperature below the melting points of potassium-silicates. Moreover they proposed that small char particles to detach from the coarse char particles. The temperature from those fines is then quickly rising, possibly beyond the melting temperature of potassium-silicates compounds. Subsequently, they collide with bed particles and form a softened phase. The deposit thickness increases with continued adhesion of fine material, but only at temperatures beyond the ash-melting range of potassium-silicates, which eventually lead to agglomeration and de-fluidization [188]. 


\subsection{Reducing the risk of FBC de-fluidization}

\subsubsection{Off-line and on-line detection methods}

Possibilities to measure the agglomeration tendency off-line include measuring the rheology of ash at high temperature and determining the composition of inorganic compounds in the fuel. Additional techniques involve the simultaneous dilatometryelectrical conductance measurements, ASTM fusion test, dilatometry,TMA, differential thermal analysis combined with thermogravimetric analysis (DTA/TGA), compression strength test of previously heated ash pellets, "yield stress" analysis, ash fusibility and disintegration of pre-heated ash experiments [27]. Measuring the compression strength in a testing device shows e.g. the point where the values deviate from their baseline, characterized by a relatively sharp increase, which has been taken as the "sintering temperature" [181].

Several analytical methods allow determining the composition of the coating layer of the agglomerate. These techniques include: chemical fractionation and analysis, controlled fluidized bed tests, determination of the melting behavior of layers on bed particles, scanning electron microscope (SEM), energy dispersive X-ray analysis (EDX), thermogravimetric analysis/differential thermal analysis (TGA/DTA), thermogravimetric analysis/ differential scanning calorimetry (TGA/DSC), thermomechanical analysis (TMA), and dynamic mechanical analysis (DMA). The early detection of the onset of agglomeration may provide the operator with an opportunity to take corrective measures to avoid the phenomenon. The controlled fluidized bed agglomeration (CFBA) method, the pressure variance calculation and the early agglomeration recognition system (EARS) are such methods. Absolute and differential pressure measurements, acoustic emission, temperature measurements, detection of relevant gas phase components, determination of the amount of fines in 
the exit gas stream, combination of various bed characteristics (bogging index) and high-frequency weight measurements are more indirect ways to detect the actual agglomeration effects and more difficult to implement in existing fluidized bed processes [27].

\subsubsection{Effect of operating parameters on the de-fluidization time}

A simple model has been developed to describe the de-fluidization time as a function of parameters such as temperature, fluidization velocity and particle size. Although the agreement between model and experimental data is very good, more work is needed for comprehensive modeling of the agglomeration phenomena [175]. A decrease in temperature can extend the de-fluidization time significantly, probably due to the much slower sintering of the agglomerates at lower temperatures. Increasing the bed temperature increases the melting rate of ash and decreases its viscosity, both parameters affecting the stickiness of the sand particle coated by ash and accelerating the de-fluidization process. The staged combustion is an effective means: primary air burns the solid residue of biomass at a relatively low temperature while the secondary air, injected above, could burn the released volatiles at a higher temperature [21, 169]. The de-fluidization time will also be extended if the gas velocity increases, since the higher turbulence will increase the breakage of incipient bonds. A bed of coarser particles will suffer from reduced mixing at a given velocity, resulting in a reduced de-fluidization time when using larger particles $[164,175]$. Recent work by Lin et al. [189] focused on the effect of the particle size distribution (PSD) on agglomeration and de-fluidization in a fluidized bed. The size of the feedstock fuel does not significantly affect the agglomeration tendencies of fluidized beds [189]. Reducing the air/fuel ratio will reduce the melting temperature of the ash, whereas the temperature of a burning particle is lower. The combination of these two 
opposing effects, therefore, results in a minor effect of the combustion stoichiometry on the agglomeration tendency [175]. Pressure has a marginal effect on the agglomeration tendency, with an increase in pressure from 10 to 15 bars producing a same effect as an increase in temperature of $10^{\circ} \mathrm{C}[170]$.

Other parameters include the sand to fuel (straw) ratio [175]. Models to describe agglomeration and de-fluidization have also been proposed: although they elucidate the underlying mechanisms and important parameters, their use cannot predict the overall behavior $[178,181,190]$.

\subsubsection{Methods to reduce the risk of agglomeration and sintering}

The previous treatment of agglomeration and sintering has already pinpointed some applicable measures to counteract agglomeration phenomena, including:

- The use of other materials as bed material as an alternative to sand: alumina $\left(\mathrm{Al}_{2} \mathrm{O}_{3}\right.$ ), magnesite $\mathrm{MgCO}_{3}$, magnesium oxide, feldspar (a major component of earth's crust), dolomite $\left(\mathrm{CaCO}_{3} \cdot \mathrm{MgCO}_{3}\right)$, ferric oxide $\left(\mathrm{Fe}_{2} \mathrm{O}_{3}\right)$, limestone or calcite $\left(\mathrm{CaCO}_{3}\right)$, lime, blast-furnace slag, mullite-sand $\left(2 \mathrm{SiO}_{2} \cdot 3 \mathrm{Al}_{2} \mathrm{O}_{3}\right)$, clay, bone ash, sillimanite $\left(\mathrm{Al}_{2} \mathrm{SiO}_{5}\right)$, bauxite, magnesite. All of these are lower in $\mathrm{SiO}_{2}$ and richer in $\mathrm{Mg}, \mathrm{Ca}$, or $\mathrm{Al}$ oxides compared to the conventional bed materials sand and quartz [26-27]. Other possible materials are zirconium salt and Ni-Mg-catalyst.

- Addition of additives to increase the melting temperature of ash during the combustion of biomass. They decrease agglomeration, corrosion, fouling and slagging $[169,191]$. Materials that can be used as additives are dolomite $\left(\mathrm{CaCO}_{3} \cdot \mathrm{MgCO}_{3}\right)$, kaolin $\left(\mathrm{Al}_{2} \mathrm{Si}_{2} \mathrm{O}_{5}(\mathrm{OH})_{4}\right)$, alumina, calcium oxide, magnesium oxide, limestone $\left(\mathrm{CaCO}_{3}\right)$, aluminite, bauxite, gibbsite $\left(\mathrm{Al}(\mathrm{OH})_{3}\right)$, andalusite. 
Kaolin, mainly consisting of kaolinite $\left(\mathrm{Al}_{2} \mathrm{O}_{3} .2 \mathrm{SiO}_{2} .2 \mathrm{H}_{2} \mathrm{O}\right)$ is an hydrated alumino silicate and has received considerable attention in the literature (e.g. $[165,173,182,193-194])$. The additives dolomite and kaolin for example improved the agglomeration index, i.e. the $\mathrm{Ca} /(\mathrm{Na}+\mathrm{K})$ ratio of the neckcomposition of agglomerates in RDF and MBM fired bed from 0.3 to 1 and 2.6, respectively, indicating a reduction in the agglomeration potential. [194]. Cofiring meat and bone meal (MBM) with Colombian coal, Greek lignite or refusederived fuel protected the bed against severe agglomeration by preventing the formation of low temperature melting alkali silicates. The bed materials were only covered with a thin ash layer of bone fragments and loose sand agglomerates. The addition of sewage sludge was investigated by van der Drift et al. [195] and was shown to increase the agglomeration temperature significantly during the combustion of straw in a lab-scale installation.

- Preliminary leaching of agglomerating compounds is possible, but expensive. When olive-oil residue underwent leaching with tap water, bed agglomeration reduced remarkably. The operation time was also extended from 165 to 900 minutes. Moreover, the alkali content of the sintered surface and the deposit layer was reduced [196], as almost all of the chlorine in the fuel was eliminated by the pre-treatment. Insufficient chlorine was thus available to give $\mathrm{KCl}$. The effect is however insufficient to completely prevent agglomeration.

- Combustor design to reduce the tendency of agglomeration. A recycling system for used bed material, automatically removing particles via a sieving installation is a possible measure. A large group of patents suggests a special bottom plate design, not to avoid the formation of agglomerates, but to remove agglomerates during operation. Moreover, combustion temperature can be 
reduced by varying the air/fuel ratio or flue gas recirculation. On lab-scale it has been occasionally reported that some weak agglomeration tendencies could be reversed by increasing the gas flow. One could expect that this effect will delay de-fluidization due to increased inter-particle forces hindering the agglomerate formation or breaking up agglomerates. Other potentially relevant techniques are concerned with local higher gas velocities or internal stirring to break up agglomerates [26-27, 197].

In literature, some cases of agglomeration problems encountered in FBCs are welldescribed, e.g. agglomeration due to the presence of $\mathrm{NaCl}$ in a fluidised bed sludge incinerator in Hamburg, Germany [30] or the more complex case $(\mathrm{Ca}, \mathrm{P}, \mathrm{Na})$ of a sludge incinerator in Dordrecht, The Netherlands [198]. Jeffers et al. [165] describe the case of a fluidised bed incinerating sludge containing large amounts of $\mathrm{Na}, \mathrm{P}, \mathrm{Ca}$, Si and S, where at usual bed temperatures, liquid silicate glass formation $\left(\mathrm{Na}_{2} \mathrm{O} \cdot 3 \mathrm{SiO}_{2}\right.$ or $\left.\mathrm{K}_{2} \mathrm{O} \cdot 3 \mathrm{SiO}_{2}\right)$ occurs. Apart from this, also liquid alkali phosphates can be formed [199]. As an example of a successful countermeasure, kaolin clay is mixed with the sludge before incineration, in order to bind the alkali metals in stable compounds with high melt temperatures [165].

The tendency to agglomerate depends on (a) the stickiness of the particles, which is a function of the temperature, (b) the available surface area - the smaller the particles the greater the surface area - and (c) particle momentum, which is a function of particle size and gas velocity. In general:

Agglomerating tendency $=$ 
$\frac{(a) \times(b)}{(c)}$

At the present time, it is not possible to predict the quantitative relationship between the variables from first principles, and experiments are essential to determine the conditions required for stable operation. It has however been demonstrated that increasing the gas velocity, makes possible stable operation at increasing temperatures is possible, as illustrated in Figure 19.

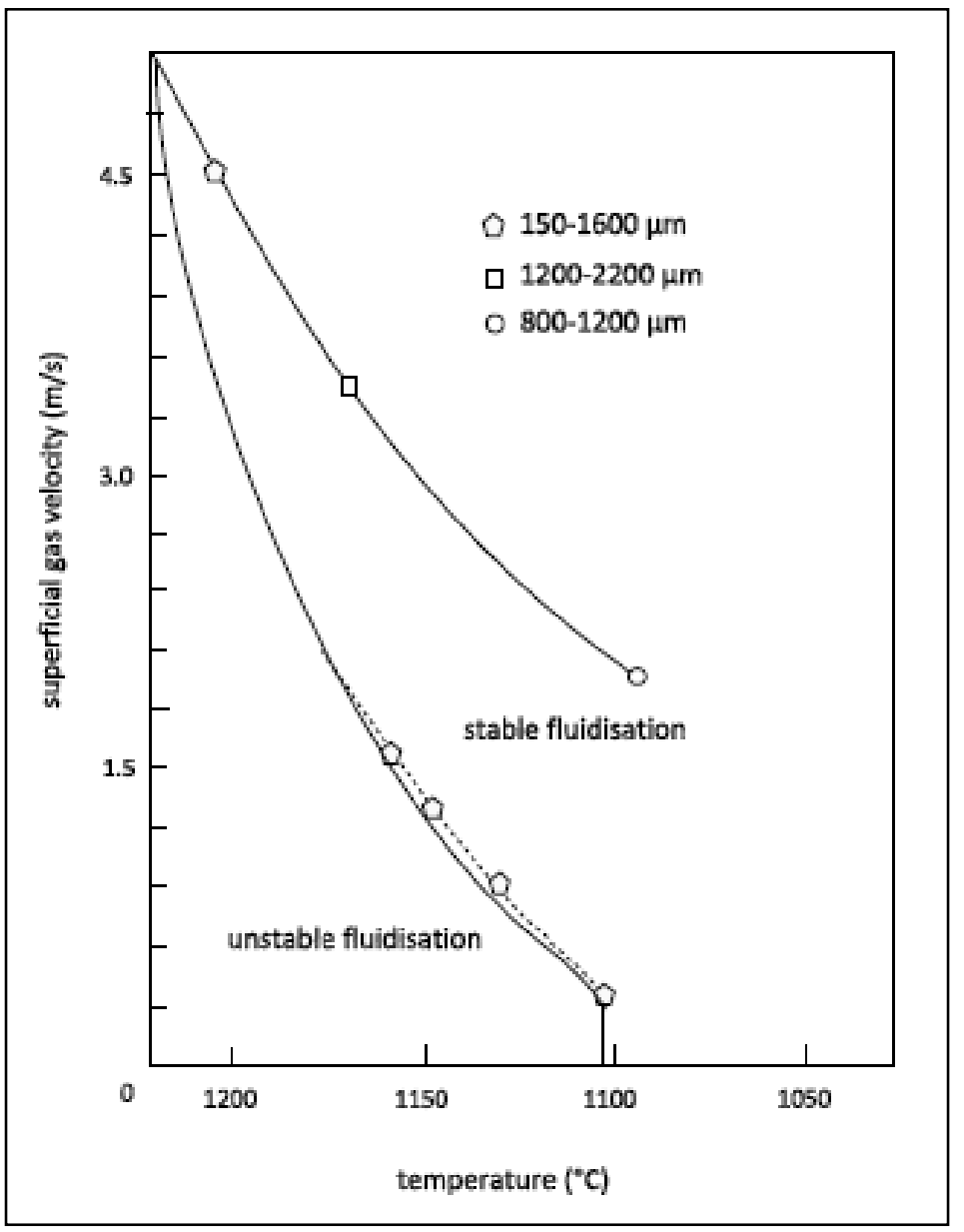

Figure 19. Effect of velocity and temperature on the agglomeration.

In BFBC to a large extent, and to a lesser extent in CFBC using fine bed material, defluidization can be influenced by the design of the gas distributor and it is essential to ensure that there are no dead areas at the plate. This might be taken to imply that a 
porous plate is best. However, the small bubbles produced in that case do not have sufficient energy to provide the vigorous movement required to remix large particles which may have started to segregate there. On the other hand, if drilled plates having large holes are used, the large distance between them (for a given pitch/diameter ratio) allows solids to settle out. Geldart and Baeyens [200] made a study of particle movement caused by bubbles and predicted the distributor plate required to guarantee particle movement over the entire plate.

\subsection{Erosion and corrosion}

Since the FBC-feedstock contain a significant amount of $\mathrm{K}, \mathrm{Cl}$, and $\mathrm{Si}$ as well as less important amounts of $\mathrm{Ca}, \mathrm{Mg}, \mathrm{Al}, \mathrm{Fe}$ and $\mathrm{Na}$, a noticeable amount of chlorine and alkali metals are released into the gas phase during combustion, as e.g. $\mathrm{HCl}, \mathrm{KCl}$, $\mathrm{KOH}$ and $\mathrm{NaCl}$. Other elements may be retained in the ash, forming potassium silicate, aluminosilicate or sulphates. $\mathrm{HCl}, \mathrm{KCl}, \mathrm{KOH}$, and $\mathrm{NaCl}$ may cause fouling, slagging, and high temperature corrosion in the combustor. Alkali metal containing compounds in the gas phase cause major corrosion problems. The release of these compounds is not affected by changes in temperature and oxygen concentration, whereas $\mathrm{KCl}$ will be transformed to $\mathrm{KOH}$ by adding steam. Some methods for controlling the emissions of alkali metal containing compounds are required if they exceed a given limit (>24 ppb) [160]. To reduce alkali metal chlorides, the biomass can be subjected to leaching [160], alkali metal binding additives can be applied, a fuel mix can be used to improve the ash composition or sulfur in elemental form or as a sulfur-containing compound can be added in the combustion zone to transform $\mathrm{KCl}$ to $\mathrm{K}_{2} \mathrm{SO}_{4}$, which is less corrosive. Chloride can also be liable to produce high emissions of $\mathrm{HCl}$ and dioxins. $\mathrm{HCl}, \mathrm{SO}_{2}$, and released alkali metal containing compounds are moreover likely to form aerosols in the flue gas [160]. It is recognized 
that the main ash forming elements (Al, Si) and the composition of the gas phase $\left(\mathrm{O}_{2}, \mathrm{~N}_{2}\right.$, and $\mathrm{H}_{2} \mathrm{O}$, etc. $)$ significantly affect the behavior of chlorine and alkali metals. It is however, also affected by the composition of the fuel, by the combustion conditions, and by the operating pressure [159, 161].

During the cooling process after combustion, potassium will condense on the coarse

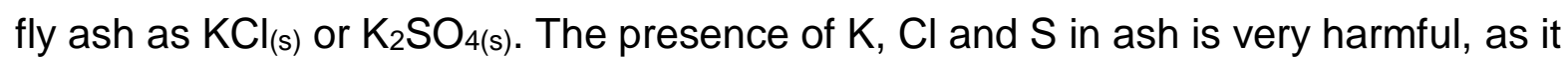
causes fouling, slagging, and high temperature corrosion in the combustor. In addition, aerosols may cause air pollution if not collected in the ash separator.

\subsection{Practical considerations for FBC boilers}

In most FBC boilers, steam-raising tubes are immersed in the bed to extract part of the heat available in the bed, typically 50\%. Extensive trials have demonstrated that, contrary to early fears, corrosion and erosion of these tubes are minimal. However, it is necessary to design the boiler in such a way that the tubes in the bed remove $50 \%$ of the heat released throughout the output range. If there is too little heat transfer to the tubes, the excess air level must be allowed to rise above the optimum, thus reducing boiler efficiency through stack heat loss. If there is too much heat transfer, the excess air level must be allowed to fall or the bed temperature lowered, both of which lead to inefficient combustion.

Because the temperature of the tubes in the bed is constant (close to the boiling point of water at the boiler pressure) and the heat transfer coefficient is almost constant over the operating range, the only available methods of modulating the heat flux to the tubes are varying the bed temperature within its restricted operational range and making provision to reduce the area of tubing in the active bed as output falls. 
In general, erosion is not a problem. Occasionally, it has been reported to occur as one of the following forms:

- Local erosion due to the impact of a high velocity air jet with entrained particles, due to a design error or a mechanical failure. In one example, the air distributor was incorrectly installed, so that the stand pipes at one side were very close to the wall. In another case, the cap of a fabricated distributor nozzle became dislodged, causing jet impact on to the tubes above.

- On vertical side walls of the combustor, cases of erosion around protrusions from the surface, particularly welds have been reported. It is essential that all welds should be ground smooth with surrounding surfaces.

- Erosion has taken place on the underside of horizontal in-bed tubes in some boilers, particularly at the 5 and 7 o'clock positions. In several instances, the erosion has been most apparent corresponding to the static bed height. This tube erosion has been overcome by welding longitudinal fins to the tubes at the worst-affected position.

- In boilers with tubes which are initially vertical and then curve to horizontal, there can be erosion on the underside of the bend.

The situation is confusing because relatively small design changes appear to have a significant impact on the rate of erosion. A possible explanation may be related to start-up in boilers with natural water circulation. With rapid start-up, high heat fluxes may occur before the water circulation is established, leading to metal overheating, oxidation and formation of low-strength scale which is susceptible to erosion. 


\subsection{Feeding}

The homogeneous distribution of the feed material is very important to avoid local radial segregation (as occurred e.g. with a single limestone feed-point at low operating velocities), and to avoid local changes in reactor environment (Figure 20). When feeding combustible material, local $\mathrm{O}_{2}$ concentrations vary, producing $\mathrm{O}_{2}$-rich zones away from the feeding point and a $\mathrm{O}_{2}$-lean where pyrolysis can occur.

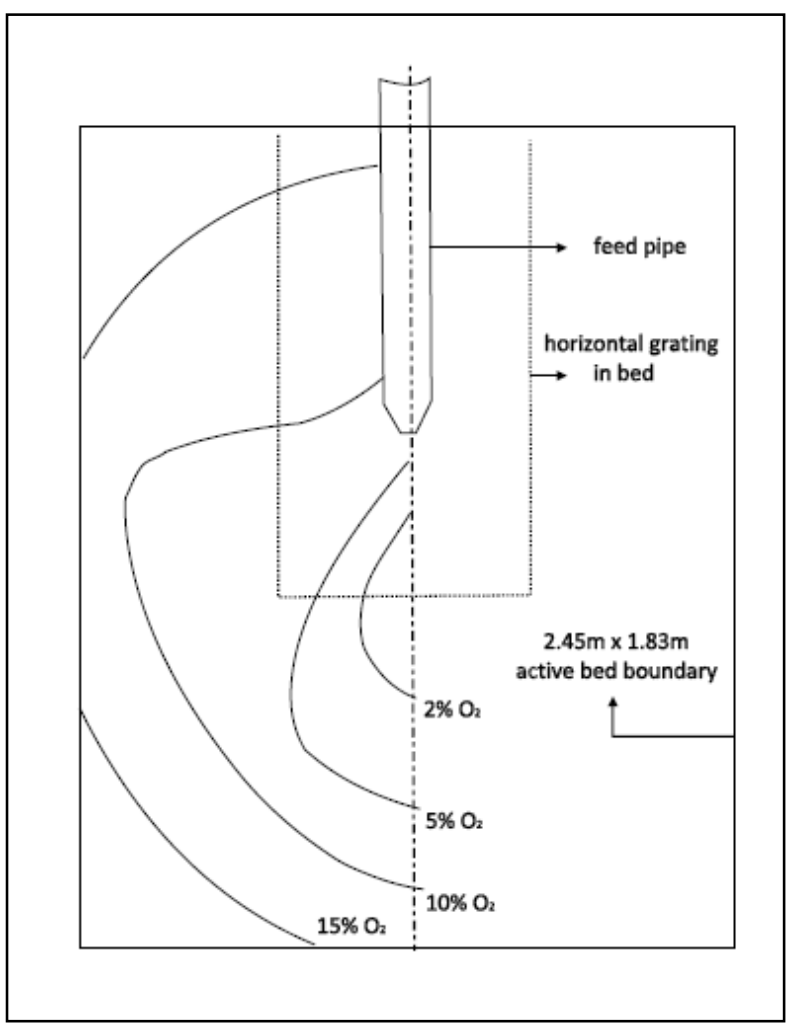

Figure 20. $\mathrm{O} 2$ concentration around the feed pipe of solid waste: $\mathrm{U}=1.9 \mathrm{~m} / \mathrm{s}$ at $860^{\circ} \mathrm{C}$, Fsolid $=1380 \mathrm{~kg} / \mathrm{h}$ at $25 \% \mathrm{H} 20$

Both effects decrease with increasing gas flow rate and decreasing bed diameter. For (ii) the reactivity of the feed material is also important. Various techniques have been industrially applied, and as a rule of thumb, feeding (i) is mostly applied near the 
distributor level and (ii) is as much as possible homogeneously distributed (as a rule of thumb, four feed points per $\mathrm{m}^{2}$ are frequently used).

The feeding methods differ according to the properties of the feed material. Liquids (gasoil, slurry, etc) are mainly pumped into the bed at various injection points near the distributor. Spray atomization on top of the bed is also used. Solids are either fed on top of the bed or pneumatically injected near the distributor level. These methods have been illustrated in various commercial applications of fluidized bed incinerators, combustors, calciners, etc and are dealt with in various references [21, 30, 201, 202].

\section{Conclusions}

Increasing amounts of waste are produced in the world, yet large geographic differences regarding sources and kinds of waste exist. The decrease of landfill opportunities instigates a growing importance of thermal treatment, aiming at volume reduction of the waste, at the destruction, capture, and concentration of hazardous substances, and evidently at the recovery of energy (WtE). Both the increasing waste recycling and incineration with energy recovery of MSW will result in a considerable reduction of the emission of $\mathrm{CO}_{2}$-equivalents (24 - 41\% by 2020 in the EU27).

Different thermal treatment techniques are used and further developed. Within the incineration techniques, the bubbling (BFBC), rotating (RFBC) and circulating (CFBC) fluidized beds, have found specific and growing applications for different waste feedstock (WWT and some types of industrial sludge, RDF, ASR, hazardous waste, biomass, plastic solid waste,...). Illustration of some of these applications is included.

This design of fluidized bed waste incinerators needs to proceed according to a set strategy, as outlined. Essential data include the identification of the individual components that make up industrial or domestic wastes, the densities and moisture 
content of the wastes, and their proximate and ultimate composition, which determine the energy content and combustion characteristics of the waste streams.

For BFBCs and RFBCs, particle sizes of the inert bed material (sand/ash) are in the 0.6-3 $\mathrm{mm}$ range. CFBCs are also operated with an inert bed, but with particles of around $0.1-0.3 \mathrm{~mm}$. The dominant operating parameter in bubbling bed fluidization is the gas velocity. A circulating fluidized bed riser operates at high velocities $(3-9 \mathrm{~m} / \mathrm{s})$ and with external circulation of bed material, corresponding to a solid circulation flux around $40-90 \mathrm{~kg} / \mathrm{m}^{2} \mathrm{~s}$.

A heat balance over the FBC determines the net energy yield. For waste high calorific waste, such as RDF, biomass, ASR and plastic solid waste, excess heat is generated in the combustor and can be recovered in a WtE mode. For low calorific waste, such as WWT sludge, auto-thermal operation generally requires pre-heating of the fluidization air, and/or pre-drying of the wet sludge feed.

To determine the required residence time of the waste in the FBC, combustion kinetics need to be considered. In the combustor, de-volatilisation and combustion of volatiles and char take place, and the required times of both phenomena can be predicted. For smaller waste particles as used in a CFBC, de-volatilisation and char combustion times are comparable, and very short. In a BFBC/RFBC, normally using coarser feed particles, the char combustion determines the overall required residence time and fixes the bed height of a BFBC, commonly at 0.5 to $0.6 \mathrm{~m}$. In a CFBC, the circulation loop offers additional flexibility and the required residence time is reflected in a combination of solids circulation flux, cyclone efficiency and riser height.

Additional design considerations for a BFBC include the sizing of its freeboard to determine the height needed for complete burn-out of the entrained hydrocarbons. 
Also the cyclone, standpipe and non-mechanical valve are essential parts of the CFBC with specific design considerations.

The formation of pollutants in FBCs depends on operating conditions as well as on fuel properties. Crucial to minimizing $\mathrm{CO}$ in the combustion gases is maintaining optimum excess air ratio and high enough temperature. During combustion, almost all the chlorine in the incinerated waste is volatilized and emitted, mostly as gaseous $\mathrm{HCl}$ with limited amounts of volatile metal chlorides. Sulfur containing compounds in the waste are oxidized and the acid gas $\mathrm{SO}_{2}$ is formed, with minor concentrations of $\mathrm{SO}_{3}$. In most commercial FBCs for waste incineration, in-bed removal of these acid gases is combined with a post-combustor injection of $\mathrm{CaO}, \mathrm{NaHCO}_{3}$ or milk of lime $\left[\mathrm{Ca}(\mathrm{OH})_{2}\right]$ as part of the dry or half wet flue gas treatment in order to reduce acid gas concentrations in the stack to far below emission standards. Nitrogen oxides $\left(\mathrm{NO}_{\mathrm{x}}\right)$ are generally emitted as NO, which accounts for up to $95 \%$ of $\mathrm{NO}_{x}$ emissions. Because of the low operating temperatures of a FBC, thermal $\mathrm{NO}_{\mathrm{x}}$ formation is limited and oxidation of the organically bound nitrogen in the fuel (fuel-N) through different pathways is found to be the main source of $\mathrm{NO}_{x}$ and $\mathrm{N}_{2} \mathrm{O}$. Figure 13 illustrates the most important pathways of the conversion of fuel-N in an FBC. Most important techniques to control and/or reduce NOx are combustion modifications, such as air and/or fuel staging, and DeNOx (SCR or SNCR). Particulate emissions from a fluidized bed combustion system include particles from incomplete combustion (soot, condensed organic matter or tar), carbonaceous residues or char, and particles from the mineral constituents in the fuel. The coarser particles $(1-10 \mu \mathrm{m})$ result from agglomeration of non-volatile elements in burning char particles; the finer particles $(<$ $1 \mu \mathrm{m})$, are largely produced from nucleation and condensation of compounds based on volatile elements such as $\mathrm{K}, \mathrm{Na}$ and $\mathrm{Cl}$. PM 10 concentrations in the flue gas 
emitted at the stack of FBCs incinerating waste are generally very low due to adequate flue gas treatment consisting of ESPs and/or baghouse filters.

Pollutants present in both the flue gas and ashes include PCDD/Fs, polyaromatic hydrocarbons (PAHs) and heavy metals and their salts. The formation of PCDD/Fs is favored in presence of products of incomplete combustion that may act as reaction surface and/ or as precursors. Also the presence of copper salts which shift the deacon reaction towards the formation of $\mathrm{Cl}_{2}$ enhances the formation of PCDD/Fs. On the other hand, high $\mathrm{SO}_{x}$ concentrations in the flue gas decrease $\mathrm{PCDD} / \mathrm{F}$ formation. Next to PCDD/Fs, also PAHs are considered as products of incomplete combustion, and found in the flue gas and in the fly ash of FBCs incinerating waste. The same techniques are used to control the PCDD/F and PAH emissions of FBCs incinerating waste i.e. a good control of the combustion process ensuring complete burnout, and injection of adsorption agents such as activated carbon in the flue gases. Heavy metals including As, $\mathrm{Cd}$, Co, $\mathrm{Cr}, \mathrm{Cu}, \mathrm{Hg}, \mathrm{Mn}, \mathrm{Ni}, \mathrm{Pb}, \mathrm{V}$ and $\mathrm{Zn}$ present in the waste incinerated in a FBC can either remain in the bottom ash, be retained in the fly ash or be vaporized and entrained with the raw flue gas, depending on the state they occur in. This so called partitioning not only depends on the physical en chemical properties of the metal, but is also related to the presence of gaseous pollutants (e.g. $\mathrm{HCl}, \mathrm{SO}_{2}$ ) and particulate matter in the flue gas. The design of the installation is also important (e.g. the location and amount of secondary air injection and to the temperatures during flue gas treatment).

Agglomeration is one of the main problems encountered in fluidized bed incineration of waste and is often the result of the in-bed formation of low melting point eutectic mixtures through the reaction of mostly alkali compounds of the waste feed with the silica bed materials: chemical transformations play an important role, and $\mathrm{Na}$ and $\mathrm{K}$ 
are the main alkali metals responsible for agglomeration, whereas calcium is a known inhibitor. The ratio $\mathrm{Ca} /(\mathrm{K}+\mathrm{Na})$ is hence presented as a useful indicator for the risk of agglomeration in a FBC. Agglomeration can already occur at relatively low temperatures. Sintering of the bed materials can also cause particle growth if the bed material is allowed to reach its sintering temperature, in excess of the operating temperature of the FBC. The specific contribution of sulfur, chlorine, iron, phosphorus, vanadium, alkali and alkaline earth metals is illustrated. Ash and/or char are not only sources of agglomeration and de-fluidization, they also lead to deposits in ducts or on boiler tubes where they reduce heat transfer, and can cause severe corrosion at high temperature. Also ash sintering may cause problems in FBCs, as it densifies particles to a compacted hard mass. It can form bed agglomerates in the furnace and in the cyclone, and can lead to plugging of the cyclone return leg. In the worst case, a complete bed de-fluidization may occur. Increasing the fluidizing velocity can prevent de-fluidization. Increasing the initial size of the bed particles, accompanied by an increased operating velocity, reduces the above phenomena, as a lower surface area is presented, and higher shear forces are generated. In addition to agglomeration and sintering, partial melting can also cause de-fluidization.

Measures to reduce the risk of de-fluidization include off-line and on-line detection, control of operating parameters and addition of additives to reduce the risk of agglomeration and sintering. 


\section{NOMENCLATURE \\ Abbreviations}

ASR automotive shredder residue

ASTM American Society for Testing and Materials

BFBC bubbling fluidized bed combustor

BHF baghouse filter

CFBA controlled fluidized bed agglomeration

CFBC circulating fluidized bed combustor

DS dry solids

DSC differential scanning calorimetry

DTA differential thermal analysis

EARS agglomeration recognition system

EDX energy dispersive X-ray analyses

ESP electrostatic precipitator

FB fluidized bed

FBC fluidized bed combustor

FGCR flue gas cleaning residue

HHV higher heating value

MBM meat and bone meal

MBT mechanical biological treatment

MSW municipal solid waste

$\mathrm{PAH} \quad$ polyaromatic hydrocarbon

PCB polychlorinated biphenyl

$\mathrm{PCBz} \quad$ polychlorinated benzene

$\mathrm{PCDD} / \mathrm{F}$ polychlorinated di-benzo-dioxines/furan

PCPh polychlorinated phenol

PE polyethylene

PET polyethylene terephthatale 


$\begin{array}{ll}\text { PM } & \text { particulate matter } \\ \text { PSD } & \text { particle size distribution } \\ \text { PVC } & \text { polyvinyl chloride } \\ \text { RDF } & \text { refuse derived fuel } \\ \text { RFBC } & \text { rotating fluidized bed combustor } \\ \text { SCR } & \text { selective catalytic reduction } \\ \text { SDF } & \text { solids derived fuel } \\ \text { SEM } & \text { scanning electron microscope } \\ \text { SNCR } & \text { selective non-catalytic reduction } \\ \text { TEQ } & \text { toxic equivalent } \\ \text { TGA } & \text { thermogravimetric analysis } \\ \text { TMA } & \text { thermomechanical analysis } \\ \text { WtE } & \text { waste-to-energy system } \\ \text { WWTP } & \text { wastewater treatment plant }\end{array}$

\section{Symbols}

$\mathrm{C}_{\mathrm{O}_{2}}$

concentration of $\mathrm{O}_{2}$

$\left[\mathrm{mol} / \mathrm{m}^{3}\right]$

$D_{O_{2}}$

diffusion coefficient for $\mathrm{O}_{2}$

$\left[\mathrm{m}^{2} / \mathrm{s}\right]$

$\overline{d_{i}}$ initial size of a particle whose terminal velocity is below $U_{t b}[\mathrm{~m}]$

d size of the burning particle, at any time

[m]

$\mu_{g}, \mu$

gas viscosity

$\begin{array}{lll}\text { Ar } & \text { Archimedes number }=\frac{\rho_{g}\left(\rho_{p}-\rho_{g}\right) g d_{p}^{3}}{\mu^{2}} & {[-]} \\ \mathrm{b} & \text { constant determined by the stoichiometry of the reaction } & {[-]} \\ \mathrm{C}_{A} & \text { concentration of } \mathrm{O}_{2} \text { in the bulk of the freeboard gas } & {\left[\mathrm{mol} / \mathrm{m}^{3}\right]} \\ D & \text { diameter of the } \mathrm{FBC} & {[\mathrm{m}]}\end{array}$ 


\begin{tabular}{|c|c|c|}
\hline$d_{p}$ & particle size & {$[\mathrm{m}]$} \\
\hline$F_{\text {solid }}$ & feed rate of combustible solids to the FBC & {$[\mathrm{kg} / \mathrm{s}]$} \\
\hline$g$ & gravitational constant & {$\left[\mathrm{m} / \mathrm{s}^{2}\right]$} \\
\hline G & solids circulation flux & {$\left[\mathrm{kg} / \mathrm{m}^{2} \mathrm{~s}\right]$} \\
\hline $\mathrm{kg}$ & mass transfer coefficient between gas and particle & {$[\mathrm{m} / \mathrm{s}]$} \\
\hline$L$ & burnout length & {$[\mathrm{m}]$} \\
\hline$R_{0}$ & radius of coal particle & {$[\mathrm{m}]$} \\
\hline$R e_{c}$ & \multicolumn{2}{|c|}{ Reynolds number at the transition velocity to turbulent fluidization [-] } \\
\hline$R e_{m f}$ & Reynolds number at the minimum fluidization velocity & {$[-]$} \\
\hline$R e_{t}$ & Reynolds number at the terminal velocity of the particle & {$[-]$} \\
\hline & $\underline{\rho_{g} U_{T R} d_{p}}$ & \\
\hline $\operatorname{Re}_{T R}$ & Reynolds number at the transport velocity $=\quad \mu$ & {$[-]$} \\
\hline$T$ & temperature & {$\left[{ }^{\circ} \mathrm{C}\right]$} \\
\hline$t_{c h}$ & burnout time for char & {$[\mathrm{s}]$} \\
\hline$t_{\text {total }}$ & total burnout time of combustible particles & {$[\mathrm{s}]$} \\
\hline$t_{v o}$ & volatiles extinction time & {$[\mathrm{s}]$} \\
\hline$U$ & superficial gas velocity & {$[\mathrm{m} / \mathrm{s}]$} \\
\hline$U_{c}$ & superficial gas velocity at the onset of turbulent fluidization & {$[\mathrm{m} / \mathrm{s}]$} \\
\hline$\bigcup_{f b}$ & superficial gas velocity in the freeboard & {$[\mathrm{m} / \mathrm{s}]$} \\
\hline$U_{\max }, U_{\min }$ & maximum and minimum operating velocity of a BFBC (Figur & (e X.7) $[\mathrm{m} / \mathrm{s}]$ \\
\hline$U_{m f}$ & minimum fluidization velocity & {$[\mathrm{m} / \mathrm{s}]$} \\
\hline$U_{T R}$ & transport velocity & {$[\mathrm{m} / \mathrm{s}]$} \\
\hline$U_{\text {trans }}$ & transition velocity & {$[\mathrm{m} / \mathrm{s}]$} \\
\hline$v_{p}$ & particle velocity & {$[\mathrm{m} / \mathrm{s}]$} \\
\hline$\varepsilon$ & voidage & {$[-]$} \\
\hline$\rho_{g}, \rho$ & gas density & {$\left[\mathrm{kg} / \mathrm{m}^{3}\right]$} \\
\hline$\rho_{M}$ & molar density & {$\left[\mathrm{mol} / \mathrm{m}^{3}\right]$} \\
\hline
\end{tabular}




\section{References}

[1] Eurostat. 2010, http://epp.eurostat.ec.europa.eu/statistics explained/index.php/Waste statistics\#Dat a sources and availability, accessed May 2011.

[2] Van Haaren R, Themelis N, Goldstein N. The state of garbage in America. BioCycle 2010;16-23.

[3] EPA, 2011, www.epa.gov/wastes/nonhaz/industrial/guide/index.htm, accessed September 2011.

[4] UNEP. Waste and Climate Change, Global trends and strategy framework. United Nations Environment Programme, Division of Technology, Industry and Economics, International Environmental Technology Centre Osaka/Shiga; 2010.

[5] Eurostat, Total sewage sludge production from urban wastewater, 2008, http://epp.eurostat.ec.europa.eu/tgm/table.do?tab=table\&init=1 \&plugin=1 \&language= en\&pcode=ten00030, accessed September 2011.

[6]Water Environment Research Foundation, Waste water sludge: a new resource for alternative energy and resource recovery, 2011, http://www.werf.org/AM/Template.cfm?Section=Home\&TEMPLATE=/CM/ContentDis play.cfm\&CONTENTID=9898, accessed September 2011.

[7] Ovam, Afval en materialen, Afvalstromen, Nieuw voortgangsrapport Slib 20082009, accessed September 2011.

[8] CEWEP ${ }^{1}, 2010$, Recycling and Waste-to-Energy in combination for sustainable waste management, www.cewep.eu, accessed May 2011.

[9] VMM. Achtergronddocument Beheer Afvalstoffen. 2007, www.vmm.be, accessed May 2011.

[10] VMM. Indicatorrapport Afval. 2010, www.vmm.be, accessed May 2010.

[11] WTERT. The ABC of Sustainable Waste Management. 2010, http://www.seas.columbia.edu/earth/wtert/fac.html, accessed May 2011.

[12] Themelis N. Thermal treatment review. Waste Management World 2007; JulyAugust:37-45.

[13] Themelis N. Developments in thermal treatment technologies. In: Proceedings of NAWTEC16-1927, 16th Annual North American Waste-to-Energy Conference, Philadelphia; May 19-21 2008, p.1-8.

[14] Bogner, J, Abdelrafie Ahmed M, Diaz C, Faaij A, Gao Q, Hashimoto S, Mareckova K, Pipatti R, Zhang T. Waste Management. In: Metz B, Davidson OR, 
Bosch PR, Dave R, Meyer LA, editors. Climate Change 2007: Mitigation. Contribution of Working Group III to the Fourth Assessment Report of the Intergovernmental Panel on Climate Change, Cambridge; 2007, p. 587-613.

[15] CEWEP², 2010, Energizing waste: a win-win situation, www.cewep.eu, accessed May 2011.

[16] Astrup, T, Fruergaard T, and Christensen TH. Recycling of plastic: accounting of greenhouse gases and global warming contributions. Waste Manage Res 2009; 27 : 763-772.

[17] Esakku S, Swaminathan A, Parthiba Karktikeyan O, Kurian J, Palinevelu K, Municipal solid waste in Chennai city, India. In: Proceedings of Sardinia 2007, Eleventh International Waste Management and Landfill. Cagliari: CISA, Environmental Sanitary Engineering Centre; 2007, p.1-9.

[18] Prognos. Resource saving and $\mathrm{CO}_{2}$ reduction potential in waste management in Europe and the possible contribution to the $\mathrm{CO}_{2}$ reduction target in 2020. 2008, www.prognos.com, accessed May 2011.

[19] Bontoux L. The incineration of waste in Europe: Issues and perspectives, 1999, A Report Prepared by IPTS for the Committee for Environment, Public Health and Consumer Protection of the European Parliament (EUR 18717 EN), 1999.

[20] Vandecasteele C, Block, C. Industrial processes for (domestic and industrial) waste incineration. In: Morselli L, Passarini F and Vassura I, editors. Waste Recovery, Strategies, Techniques and Applications in Europe, Milano: Franco-Angeli; 2009, p.174-187.

[21] Baeyens J, Geldart, D. Solids Mixing. In: Geldart D, editor. Gas Fluidisation Technology, New York: John Wiley \& Sons Ltd; 1986, p. 97-122.

[22] Mahmoudi S, Baeyens J, Seville JPK. The solids flow in the CFB riser quantified by single radioactive particle tracking. Powder Technol 2011;211:135-143.

[23] Mahmoudi S, Baeyens J, Seville JPK. NOx formation and selective non catalytic reduction (SNCR) in a fluidized bed combustor of biomass. Biomass Bioenerg 2010;34:1393-1409.

[24] Brems A, Chan CW, Seville JPK, Parker D, Baeyens J. Modelling the transport disengagement height in fluidized beds. Adv Powder Technol 2011;22:155-161.

[25] Koornneef J, Junginger M, Faaij A. Development of fluidized bed combustion An overview of trends, performance and cost. Prog Energ Combust 2007;33:19-55.

[26] Mettanant V, Basu P, Butler J. Agglomeration of biomass fired fluidized bed gasifier and combustor. Can J Chem Eng 2009;87:656-684. 
[27] Bartels M, Lin W, Nijenhuis J, Kapteijn F, van Ommen J. Agglomeration in fluidized beds at high temperatures: Mechanisms, detection and prevention. Prog Energ Combust 2008; 34:633-666.

[28] Indaver. 2011, http://www.indaver.be, accessed July 2011.

[29] Nowak, W. Clean coal fluidized-bed technology in Poland. Appl Energ 2003; 74:405-413.

[30] Baeyens J, Van Puyvelde F. Fluidized bed incineration of sewage sludge: a strategy for the design of the incinerator and the future for incinerator ash utilization. J Hazard Mater 1994;37:179-190.

[31] Ogada T, Werther,J. Combustion characteristics of wet sludge in a fluidized bed: release and combustion of the volatiles. Fuel 1996;75: 617-626.

[32] Vermeulen I, Van Caneghem J, Block C, Baeyens J, Vandecasteele C. Automotive shredder residue (ASR): reviewing its production from end-of-life vehicles (ELV's) and its recycling, energy or chemicals' valorization. J Hazard Mater 2011;190:8-27.

[33] Saxena SC, Jotshi CK. Fluidized bed incineration of waste materials. Prog Energ Combust 1996;22:401-425.

[34] Rickman WS, Holder ND, Young DT. Circulating bed incineration of hazardous wastes. Chem Eng Prog 1985;81:34-38.

[35] Stamatelopoulos GN, Semedard JC, Darling S. Operational experience from the first $300 \mathrm{MWel}$ CFB plant in the P.R. of China. In: Werther W, Nowak W, Wirth K-E, Hartge E-U, editors. Proceedings of the $9^{\text {th }}$ International Conference on Circulating Fluidized Beds, Hamburg: Tu Tech Innovation GmbH; 2008, p. 535-540.

[36] Yi J, Sauer H, Leuschke F, Baege, R. What is possible to achieve on flue gas cleaning using the CFB technology. In: Cen, K., editor. Circulating Fluidized Bed Technology VIII, Beijing: Int. Academic Publ; 2005, p. 836-843.

[37] Sauer H, Porter DE. Dry Removal of Gaseous Pollutants from Flue Gases with the Circulating Fluid Bed Scrubber. IMechE report C479/022, 1994.

[38] Baege R, Sauer H. Recent developments on CFB FGD technology. VCG Powertech-2; 2002:57-60.

[39] Leuschke F, Bleckwehl S, Ratschow L, Werther J. Flue gas de-sulphurization in a circulating fluidized bed: Investigation after 10 years of successful commercial operation at the facility of Pilsen/Cz. In: Werther W, Nowak W, Wirth K-E, Hartge E$U$, editors. Proceedings of the $9^{\text {th }}$ International Conference on Circulating Fluidized Beds, Hamburg:Tu Tech Innovation GmbH; 2008, p.943-948. 
[40] Van de Velden M, Dewil R, Baeyens J, Josson L, Lanssens P. The distribution of heavy metals during fluidized bed combustion of sludge (FBSC). J Hazard Mater 2008;151:96-102.

[41] Nissan. Sustainability Report 2005.

[42] Van de Velden M, Baeyens J, Dougan B, McMurdo A. Investigation of operational parameters for an industrial CFB combustor of coal, biomass and sludge. China Part 2007;5:247-254.

[43] Vermeulen I, Van Caneghem J, Block C, Van Brecht A, Wauters G, Vandecasteele $\mathrm{C}$. Energy recovery from heavy ASR by co-incineration in a fluidized bed combustor. Submitted to Clean Technol Environ Policy; 2012.

[44] Van de Velden M, Baeyens J, Smolders K. Solids mixing in the riser of a circulating fluidized bed. Chem Eng Sci 2007;62:2139-2153.

[45] Van de Velden M, Baeyens J, Seville JPK, Fan X. The solids in the riser of a circulating fluidized bed (CFB) viewed by Positron Emission Particle Tracking (PEPT). Powder Technol 2008;183:290-296.

[46] Khan AA, de Jong W, Jansens PJ, Spliethoff $H$. Biomass combustion in fluidized bed boilers: potential problems and remedies. Fuel Process Technol 2009;90:21-50.

[47] Krzywanski J, Czakiert T, Muskala W, Sekret R, Nowak W. Modeling of solid fuel combustion in oxygen-enriched atmosphere in circulating fluidized bed boiler: Part 1: The mathematical model of fuel combustion in oxygen-enriched CFB environment. Fuel Proces Technol 2010;91:290-295.

[48] Koukouzas N, Ward CR, Papanikolaou D, Li Z, Ketikidis C. Quantitative evaluation of minerals in fly ashes of biomass, coal and biomass-coal mixture derived from circulating fluidized bed combustion technology. J Hazard Mater 2009;169:100107.

[49] Gungor A. Effects of pressure on particle velocity profile in CFBS. In: : Werther W, Nowak W, Wirth K-E, Hartge E-U, editors. Proceedings of the $9^{\text {th }}$ International Conference on Circulating Fluidized Beds. Hamburg:Tu Tech Innovation GmbH; 2008, p.75-80.

[50] Smolders K, Baeyens J. Operating parameters for the CFB processing of biomass. In: Bridgwater AV, editor. Pyrolysis and gasification of biomass and waste, Newbury: CPL-Press;2003, p. 631-640.

[51] Anders $R$, Beisswenger $H$, Plass $L$. Clean and low cost energy from atmospheric and pressurized Lurgi CFB systems, In: Basu P, Horio M, Hasatani M, editors.

Circulating fluidized bed technology III, New York: Pergamon Press;1991,p. 431-437. 
[52] Dry RJ, Lanauze RD. Combustion in fuidised beds. Chem Eng Prog 1990;86:3147.

[53] Reh L. Fluidized bed processing, Chem Eng Prog 1971;67:58-63.

[54] Hallström C, Karlsson R. Waste incineration in circulating fluidized bed boilers. In: Basu P, Horio M, Hasatani M, editors. Circulating fluidized bed technology III, New York: Pergamon Press; 1991, p. 417-422.

[55] Gulyurtlu I, Boavida D, Abelha P, Lopes MH, Cabrita I. Co-combustion of coal and meat and bone meal. Fuel 2005;84:2137-2148.

[56] Hernandez-Anatol FD, Ryu C., Sharifi VN, Swithenbank J. Combustion of refusederived fuel in a fluidised bed. Chem Eng Sci 2007;62:627-635.

[57] Abelha P, Gulyurtlu I, Cabrita I. Release of nitrogen precursors from coal and biomass residues in a bubbling fluidized bed. Energy and Fuels 2008;22:363-371.

[58] European Commission. Reference Document on the Best Available Techniques for Waste Incineration. Seville: European Commission; 2006.

[59] Chyang CS, HanYL, Wu LW, Wan HP, Lee HT, Chang YH. An investigation on pollutant emissions from co-firing of RDF and coal. Waste Manage 2010;30:13341340.

[60] Boavida D, Abelha P, Gulyurtlu I, Cabrita I. Co-combustion of coal and nonrecyclable paper and plastic waste in a fluidised bed reactor. Fuel 2003;82:19311938.

[61] Gulyurtlu I, Abelha P, Boavida D, Seabra J, Chaleta N, Cabrita I. The implications of burning a blend of waste materials in a fluidized bed combustor. $\mathrm{J}$ Energ Resour-ASME 2006;128:118-122.

[62] Atimtay AT, Kaynak B. Co-combustion of peach and apricot stone with coal in a bubbling fluidized bed. Fuel process technol 2008;89:183-197.

[63] Cao Y, Zhou H, Fan J, Zhao H, Zhou T, Hack P, Chan CC, Liou JC, Pan WP. Mercury emissions during cofiring of sub-bituminous coal and biomass (chicken waste, wood, coffee residue and tobacco stalk) in a laboratory scale fluidized bed combustor. Environ Sci Technol 2008;42:9378-9384.

[64] Demirbas A. Co-firing coal and municipal solid waste. Energ source 2008;30:361-369.

[65] Fryda L, Panopoulos K, Vourliotis P, Kakaras E, Pavlidou E. Meat and bone meal as secondary fuel in fluidized bed combustion. P Combust Inst 2007;31:28292837. 
[66] Gulyurtlu I, Crujeira AT, Abelha P, Cabrita I. Measurements of dioxin emissions during co-firing in a fluidised bed. Fuel 2007;86:2090-2100.

[67] Huotari J, Vesterinen R. PCDD/F emissions from co-combustion of RDF with peat, wood waste and coal in FBC boilers. Hazard Waste Hazard Mater 1996;13:110.

[68] Izquirdo M, Moreno N, Font O, Querol X, Alvarez E, Antenucci D, Nugteren H, Luna Y, Fernandez-Pereira C. Influence of the co-firing on the leaching of trace pollutants from coal fly ash. Fuel 2008;87:1958-1966.

[69] Kaynak B, Topal H, Atimtay AT. Peach and apricot stone combustion in a bubbling fluidized bed. Fuel Process Technol 2005;86:1175-1193.

[70] Lopes H, Abelha P, Lapa N, Oliveira JS, Cabrita I, Gulyurtlu I. The behaviour of ashes and heavy metals during the co-combustion of sewage sludges in a fluidised bed. Waste Manage 2003;23:859-870.

[71] Lopes H, Gulyurtlu I, Abelha P, Crujeira T, Salema D, Freire M, Pereira R, Cabrita I. Particulate and PCDD/F emissions from coal co-firing with solid biofuels in a bubbling fluidized bed reactor. Fuel 2009;88:2373-2384.

[72] Lu R, Purushothama S, Yang X, Hyatt J, Pan WP, Riley JT, Lloyd W. TG/FTIR/MS study of organic compounds evolved during the co-firing of coal and refuse-derived fuels. Fuel Process Technol 1999;59:35-50.

[73] Madhiyanon T, Sathitruangsak P, Soponronnarit S. Co-combustion of rice husk with coal in a cyclonic fluidized-bed combustor ( $\Psi$-FBC). Fuel 2009;88:132-138.

[74] Senneca O. Characterisation of meat and bone mill for coal co-firing. Fuel 2008;87:3262-3270.

[75] Varol M, Atimtay AT. Combustion of olive cake and woal in a bubbling fluidized bed with secondary air injection. Fuel 2007;86:1430-1438.

[76] Xie W, Liu K, Pan WP, Riley JT. Interaction between emissions of $\mathrm{SO}_{2}$ and $\mathrm{HCl}$ in fluidized bed combustors. Fuel 1999;78:1425-1436.

[77] Xie KC, Zhao MJ. Cofiring of coal and refuse derived fuel in a new type of internally circulating fluidized bed system. Energy Sources 2003;25:1073-1081.

[78] Avidan AA, Yerushalmi J. Bed expansion in high velocity fluidization. Powder Technol 1982;32:223-232.

[79] Yerushalmi J, Crankfurt NT. Further studies of the regimes of fluidization. Powder Technol 1979;24:187-205.

[80] Wu SY, Baeyens J. Effect of operating temperature on minimum fluidization velocity. Powder Technol 1991;67(2): 217-220. 
[81] Bi HT, Grace JR. Effect of measurement method on the velocities used to demarcate the onset of turbulent fluidization. Chem Eng J 1995;57:261-271.

[82] Bi HT, Grace JR. Flow regime diagrams for gas-solid fluidization and upward transport. Int J Multiphas Flow 1995;21:1229-1236.

[83] Whitehead A, Dent D. Influence of distributor pressure-drop uniformity on large fluidized-bed systems. AICHE J. 1982;28:169-172.

[84] Van de Velden M, Baeyens J, Boukis I. Modeling CFB pyrolysis biomass reactors. Biomass Bioenerg 2008;32:128-139.

[85] Baeyens J. Modeling approach to the effect of equipment scale on fluidized bed heat transfer data. Journal of Powder and Bulk Solids Technology 1980;4:1-9.

[86] Boroduyla VA, Dikalenko VI, Palchonok Gl, Stanchits LK. Fluidized bed combustion of solid biological waste and low-grade fuels: experiments and modeling. In: Large JF, Laguerie C, editors. Fluidization VIII, Tours;1995, p.351-358.

[87] Lanauze RD. Fundamentals of coal combustion. In: Davidson JF, Klift R, Harrison D, editors. London: Academics Press; 1985, p. 631-674.

[88] Baeyens J, Geldart D. Fluidised bed incineration: a design approach for complete combustion of hydrocarbons. In: Davidson JF, Keairns D, editors. Fluidisation. Cambridge: Cambridge University Press; 1978, p. 264-269.

[89] Couturier MF, Stevens D. Capture efficiency of an industrial CFB cyclone. In: Avidan AA, editor. Circulating Fluidized Bed Technology IV, AIChE, New York; 1994, p. 540-544.

[90] Fassani FL, Goldstein L. A study of the effect of high inlet solids loading on a cyclone separator pressure drop and collection efficiency. Powder Technol 2000;107: 60-65.

[91] Bricout $\mathrm{V}$ and Louge MY. Measurements of cyclone performance under conditions analogous to pressurized circulating fluidization. Chem Eng Sci 2004;59:3059-3070.

[92] Andreux R, Fershneider G, Hémati M, Simonin O. Experimental study of a fast gas-particle separator. Chem Eng Res Des 2007;85:808-814.

[93] Chen J, Shi M. A universal model to calculate cyclone pressure drop, Powder Technol 2007;171:184-191.

[94] Cortés C, Gil A. Modeling the gas and particle flow inside cyclone separators, Prog Energ Combust 2007;33:409-542.

[95] Dewil R, Baeyens J, Caerts B. CFB Cyclones at high temperature: operational results and design assessment. Particuology 2008;6:149-156. 
[96] Chan CW, Seville JPK, Fan X, Baeyens J. Particle Motion in CFB cyclones as observed by Positron Emission Particle Tracking. Ind Eng Chem Res 2009;48:253261.

[97] Leung LS, Jones PJ. Flow of gas-solid mixtures in standpipes: a review. Powder Technol 1978;20:145-160.

[98] Knowlton TM, Mountziaris TJ, Jackson R. The effect of pipe length on the gravity flow of granular materials in vertical standpipes. Powder Technol 1986;47:115-128.

[99] Mountziaris TJ, Jackson R. The effects of aeration on the gravity flow of particles and gas in vertical pipes. Chem Eng Sci 1991;46:381-407.

[100] Smolders K, Baeyens J. The operation of L-valves to control standpipe flow. Adv Powder Technol 1995;6:163-176.

[101] Li Y, Lu Y, Wang F, Han K, Mi W, Chen X, Wang P. Behaviour of gas-solid flow in the downcomer of a circulating fluidized bed with a V-valve. Powder Technol 1997; 91:11-16.

[102] O'Dea DP, Chong YO, Leung LS. Experimental study of transitional packed flow bed in standpipe. Powder Technol 1998;55:223-224.

[103] Srivastava A, Sundaresan S. Role of wall friction in fluidization and standpipe flow. Powder Technol 2002;124:45-54.

[104] Chan CW, Seville J, Fan X, Baeyens J. Solid particle motion in a standpipe as observed by Positron Emission Particle tracking. Powder Technol 2009;194:58-66.

[105] Knowlton TM, Hirsan I. L-valves characterised for solids flow. Hydrocarbon process 1978;3:149-156.

[106] Geldart D, Jones $P$. The behavior of L-valves with granular powders. Powder Technol 1991;67:163-174.

[107] Ozawa M, Tobita S, Mii T, Tomoyasu TY, Takebayashi Y, Suzuki K. Flow pattern and flow behaviour of solid particles in L-valve. In: Basu P, Horio M, Hasatani M, editors. Circulating fluidized bed technology III, New York: Pergamon Press; 1991, p. $615-620$.

[108] Yang WC, Knowlton TM. L- valve equations. Powder Technol 1993;77:49-54.

[109] Zheng Q, Ma Z, Wang AB. Experimental study of the flow pattern and flow behaviour of gas-solid two phase flow in L-valve. Avidan AA, editor. Circulating Fluidized Bed Technology IV. New York: AIChE; 1994, p. 246-252.

[110] Arena U, Langeli CB, Cammarota A. L-valve behaviour with solids of different size and density. Powder Technol 1998:98:231-240. 
[111] Yang TY, Leu, LP. Multi-resolution analysis of wavelet transform on pressure fluctuations in an L-valve. Int J Multiphas Flow 2008;34:567-579.

[112] Chan CW, Seville J, Fan X, Baeyens J. Particle motion in L-valve as observed by positron emission particle tracking. Powder Technol 2009;193:137-149.

[113] Kouprianov VI, Permchart W. Emissions from a conical FBC fired with a biomass fuel. Appl. Energy 2003;74:383-392.

[114] Indaver NV. Sustainability report 2010. Mechelen: J. Artois; 2011.

[115] Kent Enviropower Limited. Allington monthly emission data. Allington: Kent Enviropower; 2011.

[116] Kerntner Restmüllverwertungs $\mathrm{GmbH}$. Thermische Behandlungsanlage Arnoldstein. Arnoldstein: KRV; 2011.

[117] Topal H, Atimtay AT, Durmaz A. Olive cake combustion in a circulating fluidized bed. Fuel 2003;82:1049-1056.

[118] Piao G, Aono S, Kondoh M, Yamazaki R, Mori S. Combustion test of refuse derived duel in a fluidized bed. Waste Manage 2000;20:443-447.

[119] Liu K, Pan WP, Riley JT. A study of chlorine behaviour in a simulated fluidized bed combustion system. Fuel 2000;79:1115-1124.

[120] Altarawneh M, Dlugogorski Z, Kennedy E, Mackie J. Mechanismes for formation, chlorination, dechlorination and destruction of polychlorinated dibenzo-pdioxins and dibenzofurans (PCDD/Fs). Prog Energ Combust Science 2009;35:245274.

[121] Vermeulen I, Block C, Vandecasteele C. Estimation of fuel-nitrogen oxide emissions from the element composition of the solid or waste fuel. Fuel 2011; Accepted for publication DOI 10.1016/j.fuel.2011.11.071.

[122] Glarborg P, Jensen AD, Johnsson JE. Fuel nitrogen conversion in solid fuel fires systems. Prog Energ Combust 2003;29:89-113.

[123] Hansson KM, Samuelsson J, Tullin C, Amand LE. Formation of HNCO, HCN, and $\mathrm{NH} 3$ from the pyrolysis of bark and nitrogen-containing model compounds.

Combust Flame 2004;137: 265-277.

[124] Winter F, Wartha $\mathrm{C}$, Hofbauer $\mathrm{H}$. $\mathrm{NO}$ and $\mathrm{N}_{2} \mathrm{O}$ formation during the combustion of wood, straw, malt waste and peat. Bioresource Technol 1999;70:39-49.

[125] Klason T, Bai XS. Computational study of the combustion process and NO formation in a small-scale wood pellet furnace. Fuel 2007;86:1465-1574. 
[126] Dagaut P, Glarborg P, Alzueta MU. The oxidation of hydrogen cyanide and related chemistry. Prog Energ Combust 2008;34:1-46.

[127] Aho MJ, Hämäläinen JP, Tummavuori JL. Importance of solid fuel properties to nitrogen oxide formation through $\mathrm{HCN}$ and $\mathrm{NH} 3$ in small particle combustion. Combust Flame 1993;95: 22-33.

[128] Hämäläinen JP, Aho MJ, Tummavuori JL. Formation of nitrogen oxides from fuel-N through HCN and NH3: a model-compound study. Fuel 1994;73:1894-1898.

[129] Chyang CS, Wu KT, Lin CS. Emissions of nitrogen oxides in a vortexing fluidized bed combustor. Fuel 2007;86:234-243.

[130] Suksankraisorn K, Patumsawad S, Vallikul P, Fugtammasan B, Accary A. Cocombustion of municipal solid waste and Thai lignite in a fluidized bed. Energ Convers Manage 2004;45:947-962.

[131] Yin C, Rosendahl LA, Kaer SK. Grate-firing of biomass for heat and power production. Prog Energ Combust 2008;34:725-754.

[132] Munir S, Nimmo W, Gibbs BM. The effect of air staged co-combustion of pulverised coal and biomass blends on $\mathrm{NO}_{x}$ emissions and combustion efficiency. Fuel 2011;90:126-135.

[133] Arden Pope C, Burnett RT, Thun MJ, Calle EF, Krewski J, Ito K et al. Lung cancer, cardiopulmonary mortality, and long-term exposure to fine particulate air pollution. J Amer Med Assoc 2002;287:1132-1141.

[134] Van Caneghem J, Block C, Vermeulen I, Van Brecht A, Van Royen P, Jaspers M, Wauters G, Vandecasteele $C$. Mass balance for POPs in a real scale fluidized bed combustor co-incineratingautomotive shredder residue. J Hazard Mater 2010;181:827-835.

[135] Van Caneghem J, Block C, Vermeulen I, Van Brecht A, Van Royen P, Jaspers $M$, Wauters $G$, Vandecasteele C. Destruction and formation of PCDD/Fs in a fluidised bed combustor co-incinerating automotive shredder residue with refuse derived fuel and wastewater treatment sludge. J Hazard Mater, accepted for publication DOI:10.1016/j.jhazmat.2011.04.064.

[136] Anthony EJ, Jia L, Grantstein DL. Dioxin and furan formation in FBC boilers. Environ Sci Technol 2001;35:3002-3007.

[137] Preto F, MecCleave R, McLaughlin D, Wang J. Dioxins/furans emissions from fluidized bed combustion of salt-laden hog fuel. Chemosphere 2005;58:935-941.

[138] Everaert K, Baeyens J. Catalytic combustion of volatile organic compounds. J Hazard Mater 2004;109:113-139. 
[139] Everaert K, Baeyens J. Catalytic deNO $\mathrm{N}_{x}$ using a $\mathrm{V}_{2} \mathrm{O}_{5}-\mathrm{WO}_{3} / \mathrm{TiO}_{2}$ fleece. In: Dechema, editors. Proceedings of Achema, Frankfurt-am-Main; 2003.

[140] Gulyurtlu I,Karunaratne DGGP, Cabrita I. The study of the effect of operating parameters on the $\mathrm{PAH}$ formation during the combustion of coconut shell in a fluidised bed. Fuel 2003;82:215-223.

[141] Janvijtsakul K, Kuprianov VI. Major gaseous and PAH emissions from a fluidized-bed combustor firing rice husk with high combustion efficiency. Fuel Process Technol 2008;89:777-787.

[142] Mastral AM, Callen MS, Garcia T. Fluidized bed combustion (FBC) of fossil and nonfossil fuels. A comparative study. Energy Fuels 2000;14:275-281.

[143] Atal A, Levendis YA. On the survivability and pyrosynthesis of PAH during combustion of pulverized coal and tire crumb. Comb Flame 1997;110:462-478.

[144] Agency for Toxic Substances and Disease Registry. Toxicological profile for lead. Atlanta: ATSDR; 2007.

[145] Agency for Toxic Substances and Disease Registry. Toxicological profile for mercury. Atlanta: ATSDR; 1999.

[146] Miller B, Dugwell D, Kandiyoti R. The fate of trace elements during the cocombustion of wood-bard with waste. Energy Fuels 2006;20:520-531.

[147] Shao J, Yan R, Chen H, Yang H, Lee DH, Liang DT. Emissions characteristics of heavy metals and organic pollutants from the combustion of sewage sludge in a fluidized bed combustor. Energy Fuels 2008;22:2278-2283.

[148] Van Gerven T, Geysen D, Stoffels L, Jaspers M, Wauters G, Vandecasteele C. Management of incinerator residues in Flanders (Belgium) and in neighbouring countries. A comparison. Waste Manage 2005;25:75-87.

[149] Abbas Z, Steenari BM, Lindqvist O. A study of $\mathrm{Cr}(\mathrm{VI})$ in ashes from fluidized bed combustion of municipal solid waste: leaching, secondary reactions and the applicability of some speciation methods. Waste Manage 2001;21:725-739.

[150] Wu SY, Baeyens J. Effect of operating temperature on biomass fluidization. Powder technol 1991;67:217-220.

[151] Shen J, Zhu S, Liu X, Zhang H, Tan J. The prediction of elemental composition of biomass based on proximate analysis. Energ Convers Manage 2010;51:983-987.

[152] Bapat DW, Kulkarni SV, Bhandarkar VP. Design and operating experience on fluidized bed boiler burning biomass fuels with high alkali ash. In: Proceedings of the 14th International Conference on Fluidized Bed Combustion. Preto FDS, Editor. New York: Vancouver ASME; 1997, p. 165-174. 
[153] Demirbas A. Calculation of higher heating values of biomass fuels. Fuel 1997;76:431-434.

[154] Demirbas A. Combustion characteristics of different biomass fuels. Prog Energ Combust 2004;30:219-230.

[155] Demirbas A. Fuel and combustion properties of bio-wastes. Energ Source 2005;27:451-462.

[156] Van Loo S, Koppenjan J. The handbook of biomass combustion and co-firing. London:Earthscan; 2008.

[157] Telmo C, Lousada J, Moreira N. Review: proximate analysis, backwise regression between gross calorific valu, ultimate and chemical analysis of wood. Biosource Technol 2010;101:3808-3815.

[158] Parikh J, Channiwala SA, Ghosal GK. A correlation for calculating elemental composition from proximate analysis of biomass materials. Fuel 2007;86:1710-1719.

[159] Wei XL, Lopez C, Puttkamer TV, Schnell U, Unterberger S, Hein KRG. Assessment of Chlorine-Alkali-Mineral Interactions during Co-Combustion of Coal and Straw. Energ Fuel 2002;16:1095-1108.

[160] Wei XL, Schnell U, Hein KRG. Behaviour of gaseous chlorine and alkali metals during biomass thermal utilisation. Fuel 2005;84:841-848.

[161] Jensen PA, Frandsen FJ, Dam-Johansen K, Sander B. Experimental investigation of the transformation and release to gas phase of potassium and chlorine during straw pyrolysis. Energ Fuel 2000;14:1280-1285.

[162] Öhman M, Nordin A. The role of kaolin in prevention of bed agglomeration during fluidized bed combustion of biomass fuels. Energ Fuel 2000;14: 618-624.

[163] Zevenhoven-Onderwater M, Öhman M, Skrifvars B-J, Backman R, Nordin A, Hupa M. Bed agglomeration characteristics of wood-derived fuels in FBC. Energ Fuel 2006;20:818-824.

[164] Chirone R, Miccio F, Scala F. Mechanism and prediction of bed agglomeration during fluidized bed combustion of a biomass fuel: effect of the reactor scale. Chem Eng J 2006;123:71-80.

[165] Jeffers S, Mullen J, Cohen A, Dangtran K. Control problem waste feeds in fluid beds. Chem Eng Prog 1999;95:59-63.

[166] Theis M, Skrifvars B-J, Zevenhoven M, Hupa M, Tran H. Fouling tendency of ash resulting from burning mixtures of biofuels. Part 2: Deposit chemistry. Fuel 2006;85:1992-2001. 
[167] Davidsson K, Åmand L, Steenari B, Elled A, Eskilsson D, Leckner B. Countermeasures against alkali-related problems during combustion of biomass in a circulating fluidized bed boiler. Chem Eng Sci 2008;63:5314-5329.

[168] Andersson C, Vattenfall AB. A method for operating a heat- producing plant for burning chlorine-containing fuels. 2002; Patent Number WO 02059526.

[169] Werther J, Saenger M, Hartge E, Ogada T, Siagi Z. Combustion of agricultural residues. Prog Energ Combust 2000; 26:1-27.

[170] Olofsson G, Ye Z, Bjerle I. Bed agglomeration problems in fluidized-bed biomass combustion. Ind Eng Chem Res 2002;41:2888-2894.

[171] Anthony E, Preto F, Ji L. Agglomeration and fouling in petroleum coke-fired FBC boilers. J Energ Resour Technol 1998;120:285-293.

[172] Chen J, Lu X. Progress of petroleum coke combusting in circulating fluidized bed boilers - A review and future perspectives. Resour Conserv Recy 2007;49:203216

[173] Bie R, Li S, Zhao Y, Yang L. (2009). Investigation on the Control of Agglomeration during Fluidized-Bed Incineration of Wastewater Containing Alkali Metal Salts. Energ Fuel 2009;23:4304-4310.

[174] Baeyens J. Fluidized bed combustion. In: Gas-solid reactions in fluidized beds, Amsterdam: Center for professional advancement;2005, Session 13.

[175] Lin W, Dam-Johansen K, Frandsen F. Agglomeration in bio-fuel fired fluidized bed combustors. Chem Eng J 2003;96:171-185.

[176] Scala F, Chirone R. An SEM/EDX study of bed agglomerates formed during fluidized bed combustion of three biomass fuels. Biomass Bioenerg 2008;32:252266.

[177] Roedder, E. Chapter 5: Silicate Melt systems In: Physics and Chemistry of the earth vol. 3. In: Ahrens LH, Press F, Rankama K, Runcorn SK, editors. New York: Pergamon Press; 1959, p. 224-297.

[178] Fernandez Llorente MJ, Carrasco Garcia JE. Comparing methods for predicting the sintering of biomass ash in combustion. Fuel 2005; 84:1893-1900.

[179] Yates J. Effects of temperature and pressure on gas-solid fluidization. Chem Eng Sci 1996;51:167-205.

[180] Yan R, Liang D, Laursen K, Li Y, Tsen L, Tay JH. Formation of bed agglomeration in a fluidized multi-waste incinerator. Fuel 2003;82:843-851.

[181] Skrifvars B, Hupa M, Backman R,Hiltunen M. Sintering mechanisms of FBC ashes. Fuel 1994;73:171-176. 
[182] Öhman M, Nordin A. The role of kaolin in prevention of bed agglomeration during fluidized bed combustion of biomass fuels. Energ Fuel 2000;14:618-624.

[183] Hartman M, Trnka O, Svoboda K, Vesely V. Agglomeration of particles and defluidization phenomena in the fluid bed. Chem Listy 2003;97:942-948.

[184] Hulkkonen S, Fabritius M, Enestam S. Application of BFB technology for biomass fuels: Technical discussion and experiences from recent projects. In: Pisupatis S, editor. Proceedings of the 17th International Conference on Fluidized Bed Combustion, Jacksonville; 2003, p. 663-671.

[185] Visser H, van Lit S, Kiel J. Biomass ash-bed material interactions leading to agglomeration in FBC. J Energ Resour Technol 2008;130:1-5.

[186] Scala, F, Chirone R, Salatino P. The influence of fine char particles burnout on bed agglomeration during the fluidized bed combustion of a biomass fuel. Fuel Proces Technol 2003;84:229-241.

[187] Arena U Mastellone, M. Defluidization phenomena during the pyrolysis of two plastic wastes. Chem Eng Sci 2000;55: 2849-2860.

[188] Manzoori A, Agarwal K. Agglomeration and defluidization under simulated circulating fluidized-bed combustion conditions. Fuel 1994;4:563-568.

[189] Lin CL, Peng TH, Wang WJ. Effect of particle size distribution on agglomeration/defluidization during fluidized bed combustion. Powder Technol 2011;207:290-295.

[190] Lin C, Wey M, Lu C. Prediction of defluidization time of alkali composition at various operating conditions during incineration. Powder Technol 2006;161:150-157.

[191] Llorente M, Laplaza J, Cuadrado R, Garcia G. Ash behaviour of lignocellulosic biomass in bubbling fluidised bed combustion. Fuel 2006;85:1157-1165.

[192] Davidsson K, Steenari B, Eskilsson D. Kaolin addition during biomass combustion in a 35 MW circulating fluidized-bed boiler. Energ Fuel 2007; 21:19591966.

[193] Kuo J, Wey M, Lin C, Chiu H. The effect of aluminum inhibition on the defluidization behavior and generation of pollutants in fluidized bed incineration. Fuel Proces Technol 2008;89:1227-1236.

[194] Öhman M, Nordin A, Lundholm K, Boström D, Hedman H, Lundberg M. Ash transformations during combustion of meat-, bonemeal, and RDF in a (bench-scale) fluidized bed combustor. Energ Fuel 2003;17:1153-1159.

[195] van der Drift A, Olsen A. Conversion of biomass, \{private\} prediction and solution methods for ash agglomeration and related problems; 1999. Petten . ECN-C99-090. http://www.ecn.nl/docs/library/rep, accessed June 2011. 
[196] Arvelakis S, Jensen P, Dam-Johansen K. Simultaneous thermal analysis (STA) on ash from high-alkali biomass. Energy \& fuels 2004;18:1066-1076.

[197] Ebara, Environmental Engineering Company; www.ebara.co.jp, Accessed August 2011.

[198] van der Knijff A, Mourits JW, van Driel D, Hartog L. Improving operations of the DRSH sludge incineration plant in the Netherlands. In: Werther J, Nowark W, Wirth KE, Hartge EU, Editors. Proceedings of Circulating Fluidized Bed Technology IX, Hamburg: TU Tech Innovation GmbH; 2008, p. 1105 - 1110.

[199] Lindström E, Sandström M, Boström D, Öhman M. Slagging Characteristics during Combustion of Cereal Grains Rich in Phosphorus. Energy Fuels 2007;21:710717.

[200] Geldart D, Baeyens J. The design of distributors for gas-fluidised beds. Powder Technol 1985;42:67-78.

[201] Radovanovic M. Fluidised bed combustion. Washington D.C.: Hemisphere publishing; 1986.

[202] Basu P, Cen K, Jestin L. Boilers and burners: Design and theory. New York: Springer; 2000. 


\section{Figure captions}

Figure 1. Treatment of MSW in EU27 [8]

Figure 2. BFBC of sewage sludge at Brugge (Belgium) [40]

(1) sludge feed, (2) fluidized bed, (3) freeboard, (4) pre-heater of primary air, $(5,6)$ secondary air, (7) air to start-up burner (8), (9) windbox, (10) distributor, (11) makeup sand, (12) exhaust to further heat recovery, ESP, pollutant abatement, stack.

Figure 3. BFBC for ASR [41]

Figure 4. Ebara-Rowitec RFBC for mixed waste at Indaver, Belgium [28]

Figure 5. CFBC at Caledonian Paper, Ayr (U.K.) [42]

Figure 6. Design strategy of fluidized bed combustors, with corresponding subsections: data gathering

Figure 7. Characteristics of the various fluidization regimes, with A and B-type powders referring to the generally accepted Geldart classification of powders.

Figure 8. Optimum mixing velocity limits

Figure 9. Heat balance [30]

Figure 10. Amount of additional fuel (38 MJ/kg) required for combustion of sewage sludge with heating value $8900 \mathrm{~kJ} / \mathrm{kg}$ dry solids, combustible concentration $50 \%$ of dry solids, temperature $800^{\circ} \mathrm{C}$, excess air $20 \%$.

Figure 11. Theoretical burn-out length versus freeboard velocity (numbers relate to the freeboard heights for commercial units listed in Figure 8)

Figure 12. Efficiency of $\mathrm{SO}_{2}$ removal by $\mathrm{CaO}$ at $\mathrm{Ca} / \mathrm{S} \sim 2.7$ versus operating velocity at different solid circulation fluxes and temperatures in a $58 \mathrm{MW}$ th CFBC

Figure 13. Most important fuel-N conversion pathways.

Figure 14. DeNOx-efficiencies in a CFBC at various $\mathrm{NH}_{3} / \mathrm{NO}_{x}$ ratios and temperatures [23]

Figure 15. Vapor pressure of relevant heavy metals and their salts [40].

Figure 16. Agglomeration mechanisms [162].

Figure 17a: Ternary diagram of the system $\mathrm{K}_{2} \mathrm{O}-\mathrm{CaO}-\mathrm{SiO}_{2}$ showing the measured composition of different zones on the surface of agglomerated samples, obtained by semi-quantitative SEM/EDX spot analyses [176]

Figure 17b: Ternary Phase diagram for the $\mathrm{K}_{2} \mathrm{O}-\mathrm{CaO}-\mathrm{SiO}_{2}$ system [177] 
Figure 18. Agglomeration of bed material after formation from the gas phase (1) or melt formation of ash components (2).

Figure 19. Effect of velocity and temperature on the agglomeration

Figure $20 . \mathrm{O}_{2}$ concentration around the feed pipe of solid waste: $\mathrm{U}=1.9 \mathrm{~m} / \mathrm{s}$ at $860^{\circ} \mathrm{C}, \mathrm{F}_{\text {solid }}=1380 \mathrm{~kg} / \mathrm{h}$ at $25 \% \mathrm{H}_{2} \mathrm{O}$ 
Table 1. MSW and industrial waste in the EU25(a) in 2002 [1].

\begin{tabular}{|l|l|l|l|l|l|l|l|l|}
\hline EU25 & $\begin{array}{l}\text { Agriculture } \\
\text { and forestry }\end{array}$ & $\begin{array}{l}\text { Mining } \\
\text { and } \\
\text { quarrying }\end{array}$ & $\begin{array}{l}\text { Manu- } \\
\text { facturing } \\
\text { industry }\end{array}$ & $\begin{array}{l}\text { Energy } \\
\text { production, } \\
\text { water } \\
\text { treatment }\end{array}$ & Construction & Others & MSW & $\begin{array}{l}\text { Hazardous } \\
\text { waste }\end{array}$ \\
\hline Mton & 29 & 300 & 425 & 127 & 510 & 17 & 241 & 58 \\
\hline kg/capita & 64 & 664 & 994 & 281 & 1126 & 28 & 531 & 129 \\
\hline
\end{tabular}

(a) EU25, prior to the EU-membership of Romania and Bulgaria 
Table 2. CFB applications [22,44-45]

\begin{tabular}{|l|l|}
\hline Reactions & References \\
\hline Combustion of coal, wood, biomass & {$[40,35,46,47-53]$} \\
\hline Waste incineration & {$[40,33-34,54]$} \\
\hline
\end{tabular}


Table 3. Density and moisture content for domestic, commercial and industrial solid waste [22]

\begin{tabular}{|c|c|c|c|c|}
\hline \multirow[b]{2}{*}{ item } & \multicolumn{2}{|l|}{$\begin{array}{l}\text { density } \\
\left(\mathrm{kg} / \mathrm{m}^{3}\right)\end{array}$} & \multicolumn{2}{|c|}{$\begin{array}{l}\text { moisture content } \\
\text { (\% by mass) }\end{array}$} \\
\hline & range & typical & range & Typical \\
\hline $\begin{array}{l}\text { LOOSE RESIDENTIAL WASTE } \\
\text { food waste (mixed) } \\
\text { paper } \\
\text { cardboard } \\
\text { plastics } \\
\text { rubber } \\
\text { garden trimmings } \\
\text { wood } \\
\text { dirt, ashes, etc. } \\
\text { ashes } \\
\text { MSW (mixed) } \\
\text { waste water treatment sludge }\end{array}$ & $\begin{array}{l}130-480 \\
40-130 \\
40-80 \\
40-130 \\
100-200 \\
60-225 \\
130-320 \\
320-1000 \\
650-830 \\
90-180 \\
1000-1050\end{array}$ & $\begin{array}{l}290 \\
85 \\
50 \\
65 \\
130 \\
100 \\
240 \\
450 \\
745 \\
130 \\
1030\end{array}$ & $\begin{array}{l}50-80 \\
4-10 \\
4-8 \\
1-4 \\
1-4 \\
30-80 \\
15-40 \\
6-12 \\
6-12 \\
5-20 \\
50-75\end{array}$ & $\begin{array}{l}70 \\
6 \\
6 \\
2 \\
2 \\
60 \\
20 \\
8 \\
6 \\
15 \\
35\end{array}$ \\
\hline $\begin{array}{l}\text { COMMERCIAL WASTE } \\
\text { food wastes (wet) } \\
\text { wooden crates } \\
\text { tree trimmings }\end{array}$ & $\begin{array}{l}475-950 \\
110-160 \\
100-180\end{array}$ & $\begin{array}{l}535 \\
110 \\
150\end{array}$ & $\begin{array}{l}5-85 \\
10-30 \\
20-80\end{array}$ & $\begin{array}{l}75 \\
20 \\
30\end{array}$ \\
\hline $\begin{array}{l}\text { INDUSTRIAL WASTE } \\
\text { chemical sludge (wet) } \\
\text { fly ash } \\
\text { oils, tars, asphalts } \\
\text { sawdust } \\
\text { textile wastes } \\
\text { wood (mixed) }\end{array}$ & $\begin{array}{l}800-1100 \\
700-900 \\
800-1000 \\
100-350 \\
100-220 \\
400-675\end{array}$ & $\begin{array}{l}1000 \\
800 \\
950 \\
290 \\
180 \\
500\end{array}$ & $\begin{array}{l}75-99 \\
2-10 \\
0-5 \\
10-40 \\
6-15 \\
10-40\end{array}$ & $\begin{array}{l}80 \\
4 \\
2 \\
15 \\
10 \\
20\end{array}$ \\
\hline $\begin{array}{l}\text { AGRICULTURAL WASTE } \\
\text { agricultural (mixed) } \\
\text { fruit wastes (mixed) } \\
\text { manure (wet) } \\
\text { vegetable wastes (mixed) }\end{array}$ & $\begin{array}{l}400-750 \\
250-750 \\
900-1050 \\
200-700\end{array}$ & $\begin{array}{l}360 \\
360 \\
1000 \\
360\end{array}$ & $\begin{array}{l}40-80 \\
60-90 \\
75-96 \\
50-80\end{array}$ & $\begin{array}{l}50 \\
75 \\
94 \\
65\end{array}$ \\
\hline
\end{tabular}


Table 4. Typical ultimate-analysis data for components in domestic, commercial and industrial solid waste [22, 57-58]

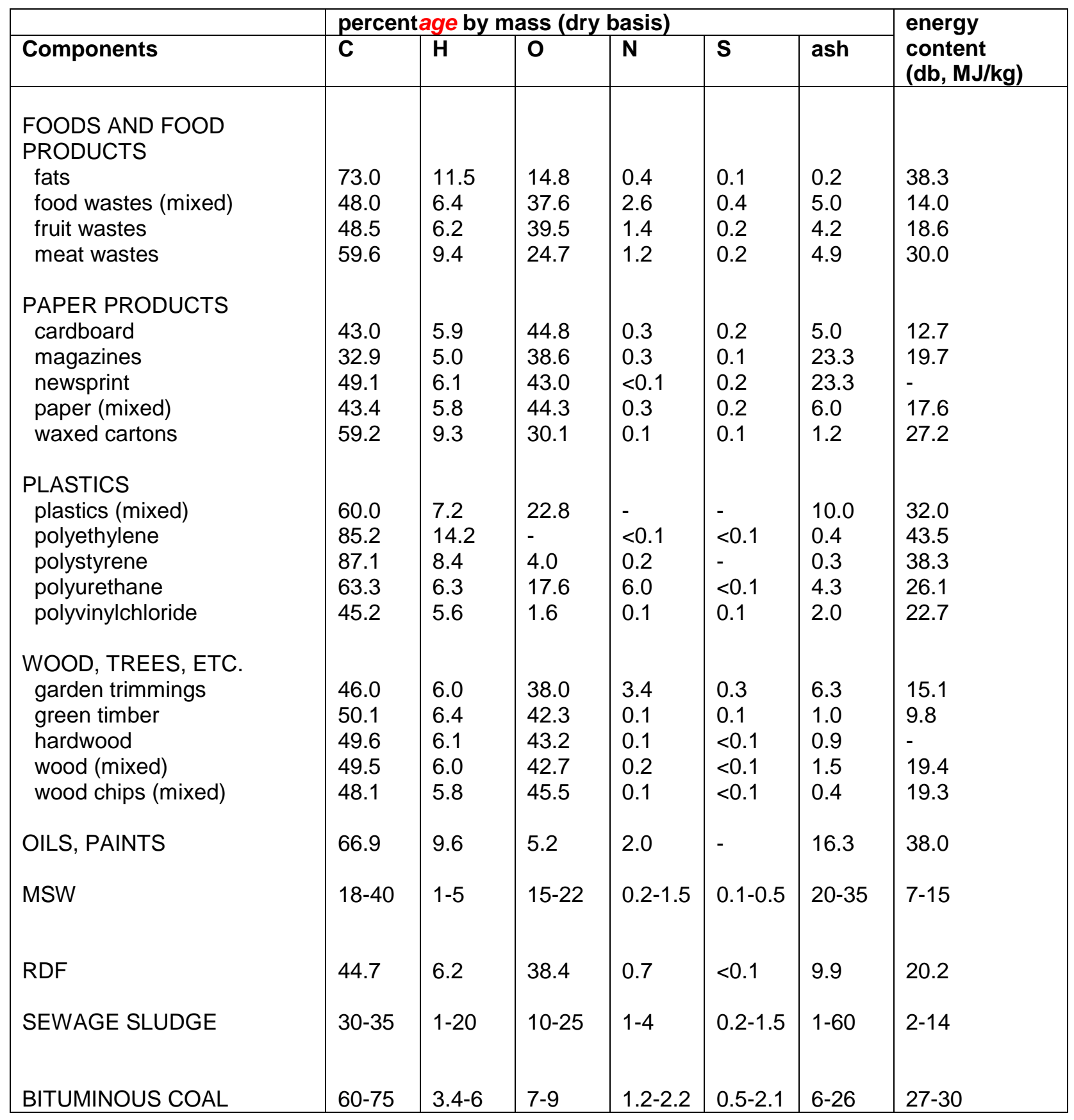


Table 5. Transition velocities

\begin{tabular}{|l|lr|l|}
\hline Utrans & Equation & $\begin{array}{l}\text { Predicted value of } \\
\mathbf{U}_{\text {trans }}{ }^{(a)}(\mathbf{m} / \mathbf{s})\end{array}$ \\
\hline$U_{\mathrm{mf}}$ & $A r=1823 \operatorname{Re}_{m f}^{1.07}+21.27 \operatorname{Re}_{m f}^{2}$ & {$[80]$} & 0.009 \\
\hline $\mathrm{U}_{\mathrm{C}}$ & $\operatorname{Re}_{c}=1.24 A r^{0.45}$ for $2<\mathrm{Ar}<10^{8}$ & {$[81]$} & 1.33 \\
\hline $\mathrm{U}_{\mathrm{TR}}$ & $\operatorname{Re}_{T R}=1.53 A r^{0.5}$ & {$[82]$} & 2.05 \\
\hline
\end{tabular}

(b) For a $100 \mu \mathrm{m}$ particle of $\rho_{p}=2600 \mathrm{~kg} / \mathrm{m}^{3}$ 
Table 6. Terminal velocities

\begin{tabular}{|l|l|l|l|l|l|l|}
\hline $\boldsymbol{d}_{p}(\mathbf{c m})$ & 0.1 & 0.5 & 1 & 1.1 & 1.5 & 2 \\
\hline $\boldsymbol{\rho}_{p}\left(\mathbf{k g} / \mathbf{m}^{3}\right)$ & 600 & 600 & 600 & 600 & 420 & 290 \\
$\boldsymbol{U}_{\boldsymbol{t}}(\mathbf{m} / \mathbf{s})$ & 1.5 & 4.9 & 7.5 & 7.9 & 7.9 & 7.9 \\
\hline
\end{tabular}


Table 7. Theoretical reaction times for waste feed particles of size $d_{p}$

\begin{tabular}{|l|l|l|l|l|l|l|}
\hline $\boldsymbol{d}_{\boldsymbol{p}}(\mathbf{c m})$ & 0.1 & 0.5 & 1 & 1.1 & 1.5 & 2 \\
\hline $\boldsymbol{t}_{\text {vo }}(\boldsymbol{s})$ & 1.51 & 12.3 & 30 & 34 & 51 & 74 \\
$\boldsymbol{t}_{c h}(\boldsymbol{s})$ & 2.26 & 56.5 & 226 & 273 & 508 & 904 \\
$\boldsymbol{t}_{\text {total }}(\boldsymbol{s})$ & 3.77 & 68.7 & 256 & 307 & 559 & 978 \\
\hline
\end{tabular}


Table 8. Auxiliary equipments of the CFB unit: some relevant publications

\begin{tabular}{|l|l|}
\hline Auxiliary equipment & Contributions \\
\hline Cyclones & {$[89-96]$} \\
\hline Standpipes & {$[97-104]$} \\
\hline L-valves & {$[105-112]$} \\
\hline
\end{tabular}


Table 9. Typical pollutant concentrations in stack emissions of MSW incinerators (daily average values in $\mathrm{mg} / \mathrm{m}^{3}$ unless otherwise stated).

\begin{tabular}{|l|l|l|l|}
\hline Pollutant & FBC [114-115] & Grate furnace [114,116] & $\begin{array}{l}\text { Limit values EU } \\
\text { Directive 2000/76/EC }\end{array}$ \\
\hline $\mathrm{CO}$ & $14-40$ & $6.0-14$ & $50^{\mathrm{a}}$ \\
$\mathrm{HCl}$ & $0.1-8$ & $0.9-6.1$ & $10^{\mathrm{a}}$ \\
$\mathrm{SO}$ as $\mathrm{SO}_{2}$ & $1-1.6$ & $1.6-10.3$ & $50^{\mathrm{a}}$ \\
$\mathrm{NO}$ as $\mathrm{NO}_{2}$ & $90-150$ & $65-145$ & $200^{\mathrm{a}}$ \\
$\mathrm{PM} 10$ & $0.6-1$ & $0.0-0.8$ & $10^{\mathrm{a}}$ \\
$\mathrm{TOC}$ & $0.9-5$ & $0.1-1.8$ & $10^{\mathrm{a}}$ \\
$\mathrm{Hg}$ & 0.013 & $<0.0005-0.013$ & $0.05^{\mathrm{b}}$ \\
$\mathrm{Cd}+\mathrm{Tl}$ & 0.0001 & $0.05^{\mathrm{b}}$ \\
$\mathrm{Sb}+\mathrm{As}+\mathrm{Pb}+\mathrm{Cr}+$ & $<0.016$ & 0.09 & $0.5^{\mathrm{b}}$ \\
$\mathrm{Co}+\mathrm{Cu}+\mathrm{Mn}+\mathrm{Ni}+\mathrm{V}$ & 0.05 & $0.001-0.01 \mathrm{ngTEQ} / \mathrm{m}^{3}$ & $0.1^{\mathrm{c}} \mathrm{ngTEQ} / \mathrm{m}^{3}$ \\
$\mathrm{PCDD} / \mathrm{Fs}$ & $0.008 \mathrm{ngTEQ} / \mathrm{m}^{3}$ & & \\
\hline
\end{tabular}

${ }^{a}$ daily average value

${ }^{\mathrm{b}}$ average values over a period of 6 to 8 hours

${ }^{c}$ average values over a period of 30 minutes to 8 hours 
Table 10. Major gaseous pollutants: concentrations formed in the combustor, recommended abatement techniques and typical concentrations to be expected in the emitted flue gas of commercial FBC boilers incinerating MSW.

\begin{tabular}{|c|c|c|c|c|}
\hline Pollutant & $\begin{array}{l}\text { Reference and } \\
\text { waste type }\end{array}$ & $\begin{array}{l}\text { Concentration formed } \\
\mathrm{mg} / \mathrm{m}^{3}\end{array}$ & $\begin{array}{l}\text { Recommended } \\
\text { abatement techniques }\end{array}$ & $\begin{array}{l}\text { Expected emission } \\
\text { concentration } \\
\mathrm{mg} / \mathrm{m}^{3}[114-115,134]\end{array}$ \\
\hline $\mathrm{CO}$ & $\begin{array}{l}\text { [60] Paper and } \\
\text { plastic waste + } \\
\text { coal } \\
\text { [61] Plastic, } \\
\text { paper, wood and } \\
\text { textile blend } \\
\text { [65] Meat\&Bone } \\
\text { meal + coal } \\
\text { [69] Peach } \\
\text { stone, Apricot } \\
\text { stone } \\
\text { [73] Rice husk + } \\
\text { coal }\end{array}$ & $\begin{array}{l}120-520^{a} \\
150-300 \\
200-1400^{a} \\
1500 \\
6500-13000 \\
60-300^{a}\end{array}$ & $\begin{array}{l}\text { Complete combustion by } \\
\text { - } \quad \text { sufficient residence } \\
\text { time (design, gas } \\
\text { velocity) } \\
\text { - optimum excess air } \\
\text { ratio by injection of } \\
\text { secondary air }\end{array}$ & $14-40$ \\
\hline $\mathrm{HCl}$ & $\begin{array}{l}\text { [59] RDF + coal } \\
\text { [66] Meat\&Bone } \\
\text { meal + coal } \\
\text { [76] PVC + coal }\end{array}$ & $\begin{array}{l}220-1600^{a} \\
25-150 \\
90-250^{a}\end{array}$ & 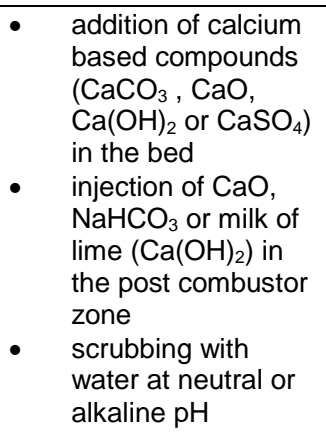 & $0.1-8$ \\
\hline $\mathrm{SO}_{x}$ & $\begin{array}{l}\text { [60] Paper and } \\
\text { plastic waste + } \\
\text { coal } \\
\text { [61] Plastic, } \\
\text { paper, wood and } \\
\text { textile blend } \\
\text { [65] Meat\&Bone } \\
\text { meal + coal } \\
\text { [66] Meat\&Bone } \\
\text { meal + coal } \\
\text { [69] Coal } \\
\text { [73] Rice husk + } \\
\text { coal } \\
\text { [76] PVC + coal }\end{array}$ & $\begin{array}{l}400-920^{a} \\
20-80 \\
650-800^{a} \\
30-1000 \\
2300 \\
10-300^{a} \\
70-250^{a}\end{array}$ & $\begin{array}{l}\text { Same techniques as for } \\
\text { the abatement of } \mathrm{HCl}\end{array}$ & $1-1.6$ \\
\hline $\mathrm{NO}_{\mathrm{x}}$ & $\begin{array}{l}\text { [59] RDF + coal } \\
\text { [60] Paper and } \\
\text { plastic waste + } \\
\text { coal } \\
\text { [65] Meat\&Bone } \\
\text { meal + coal } \\
\text { [61] Plastic, } \\
\text { paper, wood and } \\
\text { textile blend } \\
\text { [63] Peach or }\end{array}$ & $\begin{array}{l}270-380^{a} \\
220-550^{a} \\
470-950^{a} \\
80-240 \\
200-300\end{array}$ & $\begin{array}{ll}- & \text { Air staging to } \\
\text { obtain } \mathrm{O}_{2} \text { lean } \\
\text { primary combustion } \\
\text { and } 3 \% \mathrm{O}_{2} \text { excess } \\
\text { in secondary } \\
\text { combustion zone } \\
\text { - SCR or SNCR }\end{array}$ & $90-150$ \\
\hline
\end{tabular}




\begin{tabular}{|c|c|c|c|c|}
\hline & Apricot stone & & & \\
\hline PM10 & $\begin{array}{l}\text { [55] Meat\&Bone } \\
\text { meal + coal } \\
\text { [71] Different } \\
\text { biomass + Coal }\end{array}$ & $\begin{array}{l}88-392 \\
250-1000\end{array}$ & $\begin{array}{l}\text { Electrostatic precipitator } \\
\text { or baghouse filter }\end{array}$ & $0.6-1$ \\
\hline PCDD/Fs & $\begin{array}{l}\text { [59] RDF + coal } \\
\text { [66] Meat\&Bone } \\
\text { meal } \\
\text { [71] Coal } \\
\text { Meat\&Bone meal } \\
\text { Straw pellets } \\
\text { [136] Wood + } \\
\text { PVC pellets } \\
\text { [137] Salt-laden } \\
\text { waste wood }\end{array}$ & $\begin{array}{l}0.39-0.45 \mathrm{ngTEQ} / \mathrm{m}^{3} \\
0.496 \mathrm{ng} \mathrm{I-TEQ} / \mathrm{m}^{3} \\
1.1 \mathrm{ng} \mathrm{I-TEQ} / \mathrm{m}^{3} \\
549 \mathrm{ng} \mathrm{I-TEQ} / \mathrm{m}^{3} \\
42950 \mathrm{ng} \mathrm{I-TEQ} / \mathrm{m}^{3} \\
0.03-0.11 \mathrm{ngTEQ} / \mathrm{m}^{3} \\
<1-120 \mathrm{ngTEQ} / \mathrm{m}^{3}\end{array}$ & $\begin{array}{ll}- & \text { Assuring complete } \\
\text { combustion (see } \\
\text { CO) } \\
\text { - } \quad \text { Limitation of flue } \\
\text { gas residence time } \\
\text { in } 200-400^{\circ} \mathrm{C} \\
\text { temperature zone } \\
\text { Injection of } \\
\text { adsorptioin } \\
\text { reagents e.g. } \\
\text { activated carbon } \\
\text { powder } \\
\text { - Catalytic oxidation }\end{array}$ & $0.001-0.01 \mathrm{ngTEQ} / \mathrm{m}^{3}$ \\
\hline PAHs & $\begin{array}{l}{[136] \text { Wood }+} \\
\text { PVC pellets } \\
\text { [140] Coconut } \\
\text { shells }\end{array}$ & $\begin{array}{l}2.74-6.92 \mu \mathrm{g} / \mathrm{m}^{3} \\
9588-43123 \mu \mathrm{g} / \mathrm{m}^{3}\end{array}$ & $\begin{array}{ll}- & \text { Assuring complete } \\
\text { combustion (see } \\
\text { CO) } \\
\text { Injection of } \\
\text { adsorptioin } \\
\text { reagents e.g. } \\
\text { activated carbon } \\
\text { powder }\end{array}$ & $0.80-7.4 \mu \mathrm{g} / \mathrm{m}^{3}$ \\
\hline
\end{tabular}


Table 11. Elemental ash composition (oxides, as percentage) of different FBC feeds

\begin{tabular}{|c|c|c|c|c|c|c|c|c|c|c|}
\hline Sample & $\mathrm{SiO}_{2}$ & $\mathrm{CaO}$ & $\mathrm{K}_{2} \mathrm{O}$ & $\mathrm{P}_{2} \mathrm{O}_{5}$ & $\mathrm{Al}_{2} \mathrm{O}_{3}$ & MgO & $\mathrm{Fe}_{2} \mathrm{O}_{3}$ & $\mathrm{SO}_{3}$ & $\mathrm{Na}_{2} \mathrm{O}$ & $\mathrm{TiO}_{2}$ \\
\hline Forest residue & 20.7 & 47.6 & 10.2 & 5.1 & 3.0 & 7.2 & 1.4 & 2.9 & 1.6 & 0.4 \\
\hline Sawdust & 26.2 & 44.1 & 10.8 & 2.3 & 4.5 & 5.3 & 1.8 & 2.1 & 2.5 & 0.4 \\
\hline Wheat straw & 50.4 & 8.2 & 24.9 & 3.5 & 1.54 & 2.7 & 0.88 & 4.2 & 3.5 & 0.09 \\
\hline Rice husks & 94.5 & 0.97 & 2.3 & 0.54 & 0.21 & 0.19 & 0.22 & 0.92 & 0.16 & 0.02 \\
\hline Chicken litter & 5.6 & 56.9 & 12.2 & 15.4 & 1.0 & 4.1 & 0.45 & 3.6 & 0.6 & 0.03 \\
\hline $\begin{array}{l}\text { Meat and bone } \\
\text { meal }\end{array}$ & 0.02 & 41.2 & 3.2 & 40.9 & 2.4 & 1.38 & 0.25 & 4.2 & 6.4 & 0.01 \\
\hline $\begin{array}{l}\text { Biomass } \\
\text { mixture }\end{array}$ & 34.8 & 13.2 & 3.1 & 18.1 & 11.4 & 2.3 & 10.4 & 4.6 & 1.25 & 0.95 \\
\hline $\begin{array}{l}\text { Demolition } \\
\text { wood }\end{array}$ & 36.3 & 21.4 & 7.0 & 5.1 & 9.7 & 4.8 & 7.3 & 4.1 & 2.8 & 1.6 \\
\hline $\begin{array}{l}\text { Furniture } \\
\text { waste }\end{array}$ & 57.2 & 13.8 & 3.7 & 0.5 & 12.1 & 3.3 & 5.6 & 0.99 & 2.3 & 0.5 \\
\hline $\begin{array}{l}\text { Mixed waste } \\
\text { paper }\end{array}$ & 28.6 & 7.6 & 0.16 & 0.2 & 53.5 & 2.4 & 0.82 & 1.7 & 0.54 & 4.4 \\
\hline $\begin{array}{l}\text { Greenhouse } \\
\text { plastic waste }\end{array}$ & 28.4 & 25.8 & 9.7 & 3.8 & 3.9 & 5.7 & 18.4 & 2.7 & 0.8 & 0.81 \\
\hline $\begin{array}{l}\text { Refuse- } \\
\text { derived fuel }\end{array}$ & 38.7 & 26.8 & 0.23 & 0.77 & 14.5 & 6.5 & 6.3 & 3.0 & 1.36 & 1.9 \\
\hline $\begin{array}{l}\text { Sewage } \\
\text { sludge }\end{array}$ & 33.3 & 13.0 & 1.6 & 15.9 & 12.9 & 2.5 & 15.7 & 2.1 & 2.3 & 0.8 \\
\hline Peat & 37.5 & 10.0 & 1.1 & 2.8 & 20.1 & 2.1 & 13.8 & 12.1 & 0.1 & 0.31 \\
\hline Coal & 54.1 & 6.6 & 1.6 & 0.5 & 23.2 & 1.8 & 6.9 & 3.5 & 0.82 & 1.05 \\
\hline Lignite & 44.9 & 13.1 & 1.5 & 0.2 & 17.1 & 2.5 & 10.8 & 8.6 & 0.48 & 0.81 \\
\hline $\begin{array}{l}\text { Sub- } \\
\text { bituminous } \\
\text { coal }\end{array}$ & 54.7 & 7.1 & 1.7 & 0.08 & 22.9 & 2.1 & 5.3 & 4.1 & 1.09 & 1.0 \\
\hline $\begin{array}{l}\text { Bituminous } \\
\text { coal }\end{array}$ & 56.1 & 4.9 & 1.6 & 0.22 & 24.8 & 1.6 & 6.7 & 2.2 & 0.77 & 1.15 \\
\hline
\end{tabular}

